\title{
Taxing Emotional Injury Recoveries: A Critical Analysis of Murphy v. Internal Revenue Service
}

\author{
Gregory L. Germain ${ }^{*}$
}

TABLE OF CONTENTS

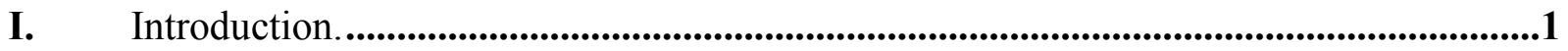

II. Procedural History of the Murphy Decision .............................................................................5

III. The Statutory Questions..........................................................................................................5

A. The Court of Appeals' Analysis. ...................................................................................

B. The Court of Appeals' Improper Focus on the Language Used in the Heading of the Award...................................................................................................7

C. Ms. Murphy Could Not Exclude Her Award Because Physical Manifestations of Emotional Distress Do Not Constitute "Personal Physical Injuries or Physical Sickness" Under IRC Section 104(a)(2)................10

D. Without an Exclusion, Was Ms. Murphy Required to Include Her Award in Gross Income? ...............................................................................................................14

IV. The Constitutional Questions.................................................................................20

A. Congress Had the Power to Tax Ms. Murphy's Damages Award Without the 16th Amendment......................................................................................20

(1) The Source of Congress's Constitutional Power to Tax...........................22

(2) Early Judicial Interpretations of the Direct Taxing Clause.......................24

(3) The Direct Taxing Clause Under Pollock. ..................................................29

(4) The Direct Taxing Clause After Pollock and Before the 16th Amendment ........................................................................................33

(5) The 16th Amendment and the Judicial Rejection of Pollock's

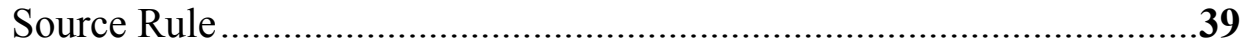

(6) Congress's Tax on Ms. Murphy's Damages Award Was Not a Direct Tax Requiring Apportionment......................................................42

(a) Congress Could Tax Ms. Murphy's Exchange of Emotional Distress Damages for Cash. .....................................................42

(b) Congress Could Tax Ms. Murphy's Human Capital. .....................45

B. Congress Had the Power to Tax Ms. Murphy's Damages Award Under the 16th Amendment.......................................................................................................46

(1) The Court of Appeals' Holding in Murphy....................................................46

\footnotetext{
* Associate Professor of Law, Syracuse University College of Law. B.A., University of California, Santa Cruz (1982), J.D. University of California, Hastings College of Law (1985), L.L.M. (Tax) University of Florida, College of Law (2001). The author is grateful for the thoughtful substantive comments provided by Professor Peter A. Bell, for the technical assistance provided by his research assistants, Lauren A. Kiley and Marco Favila, and for the secretarial support provided by Anne Hensberry.
} 
(2) The Historical Meaning of "Income" Under the 16th Amendment Before Macomber ........................................................................................47

(3) Constitutionalizing Realization: The Troubled History of Eisner v. Macomber and the Meaning of Income........................................................58

(4) Ms. Murphy Realized Income Because She Had No Basis in Her Human Capital. .............................................................................................66

(5) Ms. Murphy's Receipts from Human Capital Were Income......................71

V. Conclusion. 


\section{Taxing Emotional Injury Recoveries: A Critical Analysis of Murphy v. Internal Revenue Service}

\section{Introduction.}

A unanimous panel of the Court of Appeals for the D.C. Circuit recently dropped a bombshell on Federal income tax jurisprudence by holding in Murphy v. Internal Revenue Service ${ }^{1}$ that Congress violated the United States Constitution by attempting to tax a personal injury award that compensated the taxpayer for emotional and reputational injuries. The decision has caused an uproar in the tax community, and many expect the decision to encourage an already booming tax protestor industry. ${ }^{2}$

The tax community's primary criticism has focused on the harm done by the decision to income tax theory and jurisprudence. ${ }^{3} \quad$ These criticisms miss the mark, however, because the decision was not moored on tax theory or jurisprudence. Rather, the court of appeals concluded that Ms. Murphy's damages award would not have been considered "income" in 1913, when the 16th Amendment to the United States Constitution was adopted, ${ }^{4}$ and therefore could not constitutionally be subject to tax. ${ }^{5}$

This paper disputes virtually every aspect of the court of appeals' decision in Murphy. The first question considered by the court of appeals in Murphy was whether Ms. Murphy's damages award was statutorily excluded from income under IRC ${ }^{6}$ section 104(a)(2). The version of IRC section 104(a)(2) applicable to Ms. Murphy's damages award excluded from income all recoveries "on account of a personal physical injury or physical sickness.", The statute also provided that "emotional distress shall not constitute a physical injury or physical sickness." 8 The court of appeals wrongly concluded that the award could not be excluded from income under IRC section 104(a)(2) because the Department of Labor hearing panel that issued the award referred only to "emotional distress" and "professional reputation" in the heading of the award. The court of appeals' focus on the language used in the heading of the award was

\footnotetext{
${ }^{1} 460$ F.3d 79 (D.C. Cir. 2006).

${ }^{2}$ See e.g. Ryan J. Donmoyer, Tax Law Ruling by Court May Encourage New Challenges (August 23, 2006), available at http://www.bloomberg.com/apps/news?pid=20601103\&sid=azSsFNBVDjJ8\&refer=us (quoting criticism from Yale Law School tax professor Michael Graetz, Former IRS Commissioner Donald C. Alexander, and University of Cincinnati Law School tax professor Paul Caron); Tax Prof Commentary after Murphy (2006), available at http://taxprof.typepad.com/taxprof_blog/2006/08/tax prof_commen.html (quoting ten tax law professors criticizing various aspects of the decision primarily on the basis of tax theory).

${ }^{3} I d$. Eight of the ten professors argued either that the decision did not comport with modern tax theory, that the decision failed to consider tax policy, or that the precise holding - that IRC § 104(a) is unconstitutional - wrongly focused on an exception to an exclusion rather than the operative provision (IRC § 61). Only two of the ten professors discussed the definitional issue, and only one professor, Stephen Bank, questioned the fundamental basis for the Court's ruling - the reliance on later pronouncements to define the 1913 meaning of "income."

${ }^{4}$ U.S. CONST. amend. XVI (1913).

${ }^{5}$ Murphy, 460 F.3d at 92 (holding IRC section 104(a)(2) unconstitutional to the extent it permits Congress to tax Ms. Murphy's emotional and reputational damage award).

${ }^{6}$ All citations to the IRC are to the Internal Revenue Code of 1986, as amended, Title 26 U.S.C. $§ 1$ et seq. (2006).

${ }^{7}$ IRC $§ 104(a)(2)$.

${ }^{8}$ IRC § 104 (flush language).
} 
misplaced. ${ }^{9}$ The court of appeals should have focused on whether Department of Labor's award, in fact, included compensation for physical injuries or physical sickness. Even the court of appeals recognized that the Department of Labor intended the award to compensate Ms. Murphy for the physical manifestations of emotional distress that she suffered. ${ }^{10}$

Instead of asking whether the language in the heading of the award was sufficiently particular, the court of appeals should have asked whether Ms. Murphy's physical manifestations of emotional distress constituted a "personal physical injury" within the meaning of the statutory language. Had the court of appeals reviewed the legislative history of the statute, as had the scores of other courts to consider the question, ${ }^{11}$ the court of appeals would have discovered that Congress did not intend physical manifestations of emotional distress to constitute a "personal physical injury or physical sickness" within the meaning of the statute. ${ }^{12}$ The court of appeals thus correctly determined that Ms. Murphy's award was not statutorily excluded from income by IRC section 104(a)(2), but for the wrong reason. ${ }^{13}$

Second, after determining that the award was not specifically excluded from income, the court of appeals in Murphy should have considered whether the income tax law required Ms. Murphy to include her award in income, so that it would be subject to taxation. ${ }^{14}$ Instead, the court of appeals wrongly concluded that the exclusion in IRC section 104(a)(2) was unconstitutional for exceeding the grant of power contained in the 16th Amendment of the United States Constitution. ${ }^{15}$ Even if the court of appeals' constitutional analysis were correct, it held the wrong provision unconstitutional. Section 104(a)(2) is not the provision of the IRC requiring Ms. Murphy's damage award to be included in income. Section 104(a)(2) is an exclusion provision. Before considering the constitutional validity of the statute, the court of appeals should have determined whether, notwithstanding the lack of an exclusion in section 104(a)(2), some other provision of the IRC required Ms. Murphy to include her award in income.

It is IRC section 61 that requires "all income from whatever source derived" to be included in gross income and thus be subject to tax. It is the application of IRC section 61 to Ms. Murphy's damages award that would be unconstitutional, if the court of appeals correctly concluded that Ms. Murphy's damage award could not constitutionally be taxed. ${ }^{16}$ To reach the constitutional question, the court of appeals should first have considered whether Ms. Murphy's damage award constituted "income" within the meaning of IRC section 61 - for if the statute did not reach Ms. Murphy's damage award, the court of appeals could not consider whether or not the statute was constitutional. ${ }^{17}$

In reaching the constitutional question, the court of appeals must implicitly have concluded that Ms. Murphy's damage award was "income" within the meaning of IRC section 61. Ironically, the court of appeals' unexpressed but necessary holding that Ms.

\footnotetext{
${ }^{9}$ See discussion infra Part III beginning on page 5 .

${ }^{10}$ See discussion infra at note 51 .

${ }^{11}$ See infra note 73.

${ }^{12}$ See discussion infra Part III.C beginning at page 10.

${ }^{13}$ See discussion infra Part III.C beginning at page 10.

${ }^{14}$ See discussion infra Part III.D beginning at page 14

${ }^{15}$ See discussion infra Part III.D beginning at page 14 .

${ }^{16} I d$.

${ }^{17}$ See infra note 35.
} 
Murphy's award constituted income within the meaning of section 61, but not within the meaning of the 16th Amendment, would have been contrary to its suggestion that the word "income" in the IRC was synonymous with the word "income" in the 16th Amendment. ${ }^{18}$

Many tax experts believe that the court of appeals should not have reached the constitutional question. ${ }^{19}$ They believe that the Ms. Murphy's award either was income under both IRC section 61 and the 16th Amendment (in which case it could constitutionally be taxed), or under neither provision (in which case the statute simply would not reach the award). This analysis ignores the evolution of the statute. Congress clearly intended for non-physical-injury awards to be included in gross income under IRC section 61 when it added the "physical injury or physical sickness" requirement to IRC section 104(a)(2) in 1996. ${ }^{20}$ Congress's intended meaning for IRC section 61 at the time it amended IRC section 104(a)(2) in 1996 should prospectively govern the interpretation of the statutory scheme. ${ }^{21}$ Thus, the court of appeals in Murphy was correct in reaching the constitutional question, although it failed to meet its obligation to first explicitly hold that IRC section 61 required Ms. Murphy's award to be included in income. By failing to properly address the statutory issue, the court of appeals in Murphy failed to address the apparent conundrum of the word "income" having a different meaning under the 16th Amendment than under IRC section $61 .^{22}$

The final question is whether Congress had the constitutional power to tax Ms. Murphy's damages award. The court of appeals concluded that Congress lacked the constitutional power to tax Ms. Murphy's compensatory personal injury award because the award did not constitute "income" within the meaning of the 16th Amendment. ${ }^{23}$ Unlike the court of appeals' two prior mistakes, in which it reached the correct conclusion for the wrong reason, this time the court of appeals' flawed constitutional analysis led to the wrong result.

\footnotetext{
${ }^{18}$ See Murphy, 460 F.3d at 85 ("The Supreme Court has held the word "incomes" in the Amendment and the phrase "gross income" in § 61(a) of the IRC are coextensive."). In fact, the Supreme Court did not say in Helvering v. Clifford, 309 U.S. 331, 334 (1940), that the word "income" in the Act and in the 16th Amendment was coextensive. The Revenue Act of 1934, 48 Stat. 680, had defined gross income to include all "gains, profits, and income derived . . . from professions, vocations, trades, businesses, commerce, or sales, or dealings in property, whether real or personal, growing out of the ownership or use of or interest in such property; also from interest, rent, dividends, securities, or the transaction of any business carried on for gain or profit, or gains or profits and income derived from any source whatever." The Court in Clifford merely stated that "The broad sweep of this language indicates the purpose of Congress to use the full measure of its taxing power within those definable categories." Id. Using the full measure of Congress's taxing power in a defined manner is different than the word income having the same meaning. Congress may have had multiple means of implimenting an income system. For example, Congress could have taxed income accruing annually rather than taxing income upon the occurrence of an event of realization. By intending the chosen system to have a broad reach does not negate the possibility that other systems could have been constitutionally chosen.

${ }^{19}$ The author engaged in a lengthy debate on the TaxProf discussion board with, among others, Professor Joseph Dodge of Florida State University College of Law over this point. Professor Dodge contended that Congress's amendment to IRC section 104(a)(2) in 1996 could not change the meaning of section 61, which should be governed by the text of the statute.

${ }^{20}$ See discussion infra beginning at note 84

${ }^{21} I d$.

${ }^{22}$ See discussion infra beginning at note 86.

${ }^{23}$ See discussion infra Part IV beginning at page 20.
} 
First, the court of appeals erred in stating, without the citation of any authority, that Congress's power to tax emanates from the 16th Amendment. ${ }^{24}$ Indeed, the Supreme Court has repeatedly and long held that the 16th Amendment granted no new power of taxation. The taxing power has always emanated from Article I of the Constitution, and has long been recognized to encompass far more than income. ${ }^{25}$ Because of the court of appeals' initial error in failing to recognize the Constitution's original grant to Congress of taxing power in Article I, the court of appeals failed to analyze the alternative constitutional bases for Congress to tax Ms. Murphy's personal injury award without apportionment - as a "duty or excise." A careful review of tax history shows that the Supreme Court repeatedly recognized Congress's ability to tax transactions, whether involving the sale or exchange of property or the sale of human capital, as duties or excises, long before the 16th Amendment was adopted. ${ }^{26}$ Ms. Murphy engaged in just such a transaction when she received cash in exchange for her emotional distress damages. Therefore, Congress had the power under Article I of the Constitution to tax Ms. Murphy's damages award even if it was not "income" under the 16th Amendment, because Ms. Murphy engaged in a transaction when she exchanged her emotional distress damages for cash.

In addition, the court of appeals erred in failing to consider whether a tax on human capital would ever be direct tax requiring apportionment under Article I of the Constitution. A careful reading of precedent suggests that the taxation of human capital, unlike financial capital, has never been treated as property or wealth, and has always been treated as a legitimate subject for indirect taxation. ${ }^{27}$

Second, the court of appeals erred in holding that Ms. Murphy's award was not income under the 16th Amendment. The court of appeals cited no credible authority for its conclusion that the adoptors of the 16th Amendment intended for compensatory recoveries not to be included in income. The court of appeals relied on two administrative rulings issued years after the adoption of the 16th Amendment and made in the light of later-rejected Supreme Court statutory interpretations. ${ }^{28}$ The court of appeals in Murphy ignored the fact that Congress has always treated wage payments as income, and wage payments are, like personal injury damage awards, payments in exchange for human capital. ${ }^{29}$ The court of appeals failed to cite any proper authority arising before or contemporaneously with the adoption of the 16th Amendment to suggest that receipts from human capital would not be considered income. Ms. Murphy received "income" within the meaning of the 16th Amendment when she received the award because her financial wealth was increased as a result of the award. The 16th Amendment gave Congress, not the courts, the power to decide whether or not the increase in financial wealth should be subject to taxation.

In sum, the court of appeals' statutory and constitutional analysis was flawed, and its conclusions were erroneous. The Constitution and the 16th Amendment gave Congress the power to decide questions of tax policy within its broad limits. The court of

\footnotetext{
${ }^{24}$ See infra note 102

${ }^{25}$ See discussion infra Part IV.A beginning at page 20.

${ }^{26}$ See discussion infra Part IV.A beginning at page 20

${ }^{27}$ See discussion infra Part IV.A(6)(b) beginning at page 45.

${ }^{28}$ See discussion infra Part IV.A(5) beginning at page 39.

${ }^{29}$ See discussion infra Part IV.A(2) beginning at page 24.
} 
appeals has usurped Congress's power over tax policy questions, and its decision threatens the smooth operation of the tax system - which is the lifeblood of government. The decision should promptly be overturned.

\section{Procedural History of the Murphy Decision}

Marrita Murphy, a former employee of the New York Air National Guard, brought a claim before the Department of Labor under various whistle blower statutes, alleging that she was blacklisted by her employer for complaining to state authorities about environmental hazards at an airbase. ${ }^{30}$ At her hearing before the Department of Labor, Ms. Murphy introduced evidence showing that she suffered physical manifestations from her emotional distress. According to the court of appeals, "Upon finding Murphy had also suffered from other 'physical manifestations of stress' including 'anxiety attacks, shortness of breath, and dizziness,' the ALJ recommended compensatory damages totaling $\$ 70,000$, of which $\$ 45,000$ was for 'emotional distress or mental anguish,' and $\$ 25,000$ was for 'injury to professional reputation' from having been blacklisted." 31

Ms. Murphy paid income taxes on her personal injury award, but then brought an action in the United States District Court against both the IRS and the United States for a tax refund and for declarative and injunctive relief. ${ }^{32}$ The government then moved to dismiss the IRS as an improper party, and sought summary judgment on the merits.

The district court denied the government's motion to dismiss, holding that the injunction claims were properly brought against the IRS, but granted the government's motion for summary judgment on the merits. The district court also denied Ms. Murphy's cross motion for summary judgment. ${ }^{33}$ Ms. Murphy appealed the grant of summary judgment to the Court of Appeals for the D.C. Circuit. The government did not appeal from the denial of its motion to dismiss the IRS.

The court of appeals began by holding that the IRS was not a proper party, and should have been dismissed. ${ }^{34}$ However, because the refund action against the United States was properly brought, the court of appeals then proceeded to consider the merits of the refund action.

\section{The Statutory Questions.}

\footnotetext{
${ }^{30}$ Murphy, 460 F.3d at 81.

${ }^{31} \mathrm{Id}$. at 82 .

${ }^{32} I d$.

${ }^{33} I d$.

${ }^{34}$ Id. The court of appeals in Murphy considered this question, even though the government had not appealed the denial of its motion to dismiss, because the issue concerned the court of appeals' jurisdiction over the IRS. Id. The court of appeals reversed the district court's refusal to dismiss the IRS, holding that the government did not waive its sovereign immunity for declaratory and injunctive relief suits in tax controversies, citing 28 U.S.C. section 2201(a) (no waiver of sovereign immunity with respect to declaratory relief actions "with respect to Federal taxes other than actions brought under section 7428 of the Internal Revenue Code of 1986."), and IRC section 7421(a) (prohibiting injunctions restraining assessment or collection of taxes). Therefore, the Court of Appeals held that the IRS was an improper party on all counts, and should have been dismissed.
} 
Before considering constitutional questions, a court must first consider whether the issue can be resolved on the basis of the statute enacted by Congress. A court must always consider the statutory question before considering the constitutional validity of the statute, because constitutional issues are to be avoided whenever possible. ${ }^{35}$ Therefore, the first real issue that the court of appeals in Murphy should have addressed was whether Ms. Murphy's award was subject to tax under the applicable statutory rules adopted by Congress in the IRC. Only after determining that Congress had in fact statutorily required Ms. Murphy's award to be included in income should the court of appeals have proceeded to determine whether the statute was constitutional.

The statutory question requires a two-step analysis: (1) was there a specific provision in the IRC allowing Ms. Murphy to exclude her award from income, and, if not, (2) was there a specific provision in the IRC requiring Ms. Murphy to include her award in income. Only if the first question is answered in the negative and the second question answered in the affirmative is it proper for the court to consider the constitutionality of the statutory scheme.

As is discussed below, the court of appeals properly considered whether Ms. Murphy could exclude her award under IRC section 104(a)(2), but its analysis was flawed. The court of appeals wrongly focused on the language used in the heading of the award to conclude that Ms. Murphy's award did not compensate her for "physical injuries or physical sickness." The court of appeals' focus on the heading used in the award was misplaced, however, because the award in fact was intended to and did compensate Ms. Murphy for the physical manifestations of emotional distress that she suffered. The real question should have been whether Ms. Murphy's physical manifestations of emotional distress constituted a "personal physical injury or physical sickness" within the meaning of IRC section 104(a)(2). The court of appeals reached the right result - that Ms. Murphy could not exclude her award from income - but for the wrong reason. The award was not excludible because physical manifestations of emotional distress do not constitute "personal physical injuries or physical sickness" within the meaning of IRC section 104(a)(2), not because the language used in the heading of the award was too general.

After concluding that Ms. Murphy could not exclude her award from income under IRC section 104(a)(2), the court should have determined whether any provision of the IRC required Ms. Murphy's award to be included in income. The proper question should have been whether IRC section 61 - the provision subjecting income to taxation was unconstitutional as applied to Ms. Murphy's damages award. The court of appeals failure to engage in the second step of the analysis ultimately caused it to hold the wrong provision unconstitutional, and enabled it to avoid addressing a difficult question of statutory interpretation: whether Ms. Murphy's award could be "income" under IRC section 61, but not "income" under the 16th Amendment. The following analysis shows that the court of appeals correctly proceeded to consider the constitutionality of the statute, although it again did so for the wrong reasons.

\footnotetext{
${ }^{35}$ See e.g. Mc Connell v. FEC, 540 U.S. 93, 180 (2003) ("WWen the validity of an act of the Congress is drawn in question, and . . . a serious doubt of constitutionality is raised, it is a cardinal principle that this Court will first ascertain whether a construction of the statute is fairly possible by which the question may be avoided,"'quoting Crowell v. Benson, 285 U.S. 22, 62 (1932)).
} 


\section{A. The Court of Appeals' Analysis.}

The first substantive issue considered by the court of appeals in Murphy was whether Ms. Murphy's damages award should be statutorily excluded from income under IRC section 104(a)(2). IRC section 104(a)(2) excluded from gross income damage awards "received . . on account of personal physical injuries or physical sickness." The flush language to section 104(a) provides "[f]or purposes of paragraph (2), emotional distress shall not be treated as a physical injury or physical sickness," except to the extent of amounts paid for medical care. ${ }^{36}$

Ms. Murphy first argued that her damages award should have been excluded from income under IRC section 104(a)(2) because she suffered a "personal physical injury" as a result of the stress of being blacklisted. ${ }^{37}$ The court of appeals did not address whether physical manifestations of emotional distress constitute "personal physical injuries" within the meaning of the statute, an issue discussed below. ${ }^{38}$ Instead, the court of appeals focused on the words used by Labor Board in the heading of its damages award. The Labor Board hearing panel titled the awards "Compensatory damage for emotional distress or mental anguish" and "Compensatory damage award for injury to professional reputation." 39 The court of appeals adopted the Government's argument that "the Board awarded her damages, not to compensate [her for that] particular injur[y] [physical manifestations], but explicitly with respect to nonphysical injuries." 40 Because the heading used by the Board in rendering its award only referred to emotional distress and reputation, the court of appeals did not consider it relevant that the Board had, in fact, found that Ms. Murphy suffered serious physical manifestations from that distress, and had considered these manifestations in setting the amount of her award. ${ }^{41}$ As a general matter, tort awards for emotional distress include all consequences of that distress, including physical manifestations. ${ }^{42}$ The court of appeals erred in focusing exclusively on the language used by the Board in the heading of the award, rather than its clear intent, which was reflected in the award, to compensate Ms. Murphy for her physical manifestations.

\section{B. The Court of Appeals' Improper Focus on the Language Used in the Heading of the Award.}

The court of appeals' focus on the heading rather than substance of the award was based on its reading of two Supreme Court cases interpreting the "on account of"

\footnotetext{
${ }^{36}$ IRC § 104(a) (flush language).

${ }^{37}$ Murphy, 460 F.3d at 9-10.

${ }^{38}$ See infra Part III.C beginning at page 10.

${ }^{39}$ Murphy, 460 F.3d at 84 ("Murphy no doubt suffered from certain physical manifestations of emotional distress, but the record clearly indicates the Board awarded her compensation only "for mental pain and anguish" and "for injury to professional reputation." The Board thus having left no room for doubt about the grounds for her award, we conclude Murphy's damages were not "awarded by reason of, or because of ... [physical] personal injuries.") (citations omitted).

${ }^{40} I d$.

${ }^{41}$ See infra beginning at note 50.

${ }^{42}$ See F. Patrick Hubbard, Making People Whole Again: The Constitutionality of Taxing Compensatory Tort Damages for Mental Distress, 49 FLA. L. REV. 725, 748 (December 1997) (purpose of tort law to make plaintiff whole).
} 
language contained in IRC section 104(a)(2). The court of appeals interpreted the Supreme Court's decision in O'Gilvie v. United States ${ }^{43}$ to require "a strong causal connection" between the physical injury and the language of the award. The court of appeals' reading of $O$ 'Gilvie is, however, quite strained.

In 1988, the plaintiffs in O'Gilvie recovered $\$ 10$ million in punitive damages in a wrongful death action against the manufacturer of a product that caused the death of their wife and mother. ${ }^{44}$ The issue in $O^{\prime}$ Gilvie was whether the punitive damage award could be excluded from income under the 1983 version of IRC $\S$ 104(a)(2), which excluded from income all awards of damages "on account of personal injuries or sickness." 45 The taxpayers in $O^{\prime}$ Gilvie argued that the punitive damage award should have been excludible from income because it would not have been recovered "but for" the personal injury to their wife and mother. ${ }^{46}$

The Supreme Court in O'Gilvie rejected the taxpayers' approach. Instead, the Court held that the statute's "on account of" language required a direct connection between the personal injury and the purpose of the remedy. The Court held that punitive damages are not awarded as compensation for personal injury, but rather to punish the wrongdoer's conduct and deter others. ${ }^{47}$ The Court therefore ruled that the punitive damages award was not "on account of" the personal injury because the remedy punitive damages - was not, as a matter of law, given "on account of" the personal injury.

The Supreme Court in O'Gilvie also relied on its prior decision in Commissioner v. Schleier, ${ }^{48}$ in which it had held that liquidated damages awarded under the Discrimination in Employment Act of 1967 ( the "ADEA") were not excludible under IRC $\S 104(\mathrm{a})$. In explaining its holding in Schleier, the Court in O'Gilvie stated:

$[\mathrm{P}]$ ain and suffering damages, medical expenses, and lost wages in an ordinary tort case are covered by the statute and hence excluded from income "not simply because the taxpayer received a tort settlement, but rather because each element ... satisfies the requirement ... that the damages were received 'on account of personal injuries or sickness."" In holding that ADEA liquidated damages are not covered, we said that they are not "designed to compensate ADEA

\footnotetext{
${ }^{43} 519$ U.S. 79 (1996).

${ }^{4} I d$. at 81 .

${ }^{45}$ IRC Section 104(a)(2) was amended in 1989 to provide that punitive damages awards "for physical injury or physical sickness" were not excluded from income. Omnibus Budget Reconciliation Act of 1989, Pub. L. No. 101-239, 103 Stat. 2106, §7641(a). The statutory amendment did not apply to written binding settlements or decrees in effect on or before July 10,1989, and was therefore not effective on the settlement in O'Gilvie. See Id. at $\S$ 7641(b)(2); O'Gilvie, 519 U.S. at 89-90. The statute was again amended in 1996 to make personal injury awards taxable in all cases, but again the statutory amendment was not retroactive and therefore did not apply to the settlement in O'Gilvie. See Small Business Job Protection Act of 1996, $\S$ 1605, Pub. L. No. 104-188, 110 Stat. 1838; O'Gilvie, 519 U.S. at 90.

${ }^{46} \mathrm{Id}$. at 82 .

${ }^{47} I d$. at 83 ("The Government says that such damages were not 'received . . on account of' the personal injuries, but rather were awarded 'on account of' a defendant's reprehensible conduct and the jury's need to punish and to deter it.").

${ }^{48} 515$ U.S. 323 (1995).
} 
victims," instead, they are "'punitive in nature."' Applying the same reasoning here would lead to the conclusion that the punitive damages are not covered because they are an element of damages not "designed to compensate . . . victims. $^{49}$

It is important to note that the Supreme Court in O'Gilvie and Schleier did not focus on what the award said the damages were for - the label used - but on the underlying legal purpose of the remedy. This is very different from the court of appeals interpretation of these cases in Murphy. Ms. Murphy's claims were brought under federal statutes that authorized awards of "compensatory damages." According to the lower court, "the Administrative Law Judge noted and the Administrative Review Board confirmed that Murphy suffered from [Bruxism and] other 'physical manifestations of stress' including 'anxiety attacks, shortness of breath, and dizziness. ${ }^{51}$ Unlike the claims in O'Gilvie and Schleier which were legally limited in a way having tax significance (punitive damages in O'Gilvie and liquidated damages for age discrimination in Schleier, both of which were, statutorily, not intended as compensation for personal injury), the claim in Murphy did not have a remedy legally limited in a way that would have tax significance. Ms. Murphy was entitled to and did recover for all of the consequences of her emotional distress, including her physical manifestations. There was nothing in the quoted language of the award to suggest that the Labor Board did not accept as true and take into account in setting the amount of the award the physical manifestations of emotional distress suffered by Ms. Murphy. Indeed, the court of appeals recognized that the Board had in fact intended, by its award, to compensate Ms. Murphy for her physical manifestations. ${ }^{52}$

The court of appeals' error in focusing on the language used in the heading of the award rather than on what the award in fact was intended to compensate was demonstrated by the Fifth Circuit's decision in Dotson v. U.S., ${ }^{53}$ where the court held that a taxpayer who recovered damages under the Employment Retirement and Income Security Act (ERISA) ${ }^{54}$ could exclude the portion of the award that was given to compensate for personal injuries, even though the courts later determined that ERISA precluded compensatory damages awards. The Dotson court held that the taxpayer could exclude the award, which had been wrongly given to compensate for damages, because the award, in fact, had been given on account of personal injuries, even though the remedy for ERISA violations was later held to be more limited. Similarly, in cases involving settlement allocations, the courts have required a factual inquiry into the true

\footnotetext{
${ }^{49} 519$ U.S. at 83-84.

${ }^{50}$ Murphy v. Internal Revenue Service, 362 F. Supp. 2d 206, 210 (D.C. 2005), rev'd 460 F.3d 79 (D.C. Cir. 2006).

${ }^{51}$ Id. citing Leveille v. New York Air National Guard, 1999 WL 966951, Recommended Decision and Order at 6 (ALJ Feb. 9, 1998.). The court of appeals also recognized this in its opinion. See infra note 52.

${ }^{52}$ Murphy, 460 F.3d at 81 ("Upon finding Murphy had also suffered from other 'physical manifestations of stress' including 'anxiety attacks, shortness of breath, and dizziness,' the ALJ recommended compensatory damages totaling $\$ 70,000$, of which $\$ 45,000$ was for 'emotional distress or mental anguish,' and $\$ 25,000$ was for 'injury to professional reputation' from having been blacklisted.”).

5387 F.3d 682 (5th Cir. 1996).

${ }^{54} 29$ U.S.C. $\S 1132(\mathrm{a})$ and 1140.
} 
nature of the award, rather than a strict focus on the labels used by the parties. ${ }^{55}$ The theory used by the Supreme Court in O'Gilvie and Schleier simply does not support the court of appeals' blunt focus on the language of the heading in the Labor Board's award, rather than the true purpose and intent of the award.

If physical manifestations of emotional injuries were excludible as "physical injuries," the courts in Murphy should have made an allocation between the physical aspects of the emotional award and the purely mental aspects of the emotional award. ${ }^{56}$ However, Congress did not intend physical manifestations of emotional distress to constitute a "personal physical injury or physical sickness" within the meaning of IRC section 104(a)(2).

\section{Ms. Murphy Could Not Exclude Her Award Because Physical Manifestations of Emotional Distress Do Not Constitute "Personal Physical Injuries or Physical Sickness” Under IRC Section 104(a)(2).}

The question that the court of appeals in Murphy should have addressed is whether an award on account of emotional injuries causing physical manifestations constitutes an award on account of "personal physical injuries or physical sickness" within the meaning of IRC section 104(a)(2). The meaning of the statutory language is greatly aided by a review of the statute's judicial and legislative history.

In 1918, Congress added language to the income tax statute to exempt damages received "on account of [personal] injuries and sickness." remained in the statute ever since. However, beginning in 1989, important judicial and statutory limitations were recognized.

In 1989, the House of Representatives proposed, and ultimately passed, a bill limiting the personal injury exclusion to "cases involving physical injury or sickness.",58 The Senate passed a bill that did not accept the House's proposed language. The Conference Committee reached a compromise providing that the exclusion for personal injury or sickness "shall not apply to any punitive damages in connection with a case not involving physical injury or physical sickness." $" 59$ This compromise was accepted by both houses and became law. ${ }^{60}$

55 See e.g. Tamberella v. Commissioner, 139 Fed. Appx. 319, (2d Cir. 2005)(focus on intent of payor); Chamberlain v. United States, 401 F.3d 335 (5th Cir. La. 2005) (prejudgment interest taxable regardless of characterization of parties or state law); Greer v. United States, 207 F.3d 322, 329 (6th Cir. 2000) (focus on motivation behind settlement); Forest v. Commissioner, 1996 U.S. App. LEXIS 3312 (1st Cir. 1996) (focus on facts and circumstances); Delaney v. Commissioner, 99 F.3d 20 (1st Cir. 1996) (ignoring party allocation and focusing on facts); Brabson v. United States, 73 F.3d 1040 (10th Cir. Colo. 1996) (prejudgment interest taxable regardless of characterization); Robinson v. Commissioner, 102 T.C. 116 (1994), rev'd in part on other grounds, 70 F.3d 34 (5th Cir. 1995) (rejecting party's allocation of 95\% of settlement proceeds to excludible claims when earlier jury verdict awarded mostly punitive damages); Bagley v. Commissioner, 105 T.C. 396 (1995) (same).

${ }^{56}$ See e.g. Bagley v. Commissioner, 105 T.C. 396 (1995) (Ignoring parties' allocation between excludible personal injuries and non-excludible emotional distress); Robinson v. Commissioner, 102 T.C. 116 (1994) (ignoring allocation made in stipulated court-approved settlement).

${ }^{57}$ Revenue Act of 1918, Child Labor Tax Acts, Pub. L. No. 65-254, § 213(b), 40 Stat 1057, 1065 (1919).

${ }^{58}$ See H.R. REP. No. 101-247, at 104, 140, 451 (1989) (emphasis added).

${ }^{59}$ See Omnibus Budget Reconciliation Act of 1989, H.R. REP. No. 101-386, at 99 (1989).

${ }^{60} \mathrm{See}$ Omnibus Budget Reconciliation Act of 1989, § 7641, PUB. LAW No. 101-239, 103 Stat. 2106 (1989). 
In 1992, the Court in Burke v. U.S. ${ }^{61}$ held that an award of damages under Title VII of the Civil Rights Act of 1964 for illegal discrimination on the basis of gender did not constitute a "personal injury" award, and thus could not be excluded from income, because the statutory remedy was limited to back pay and injunctive relief rather than compensating for a tort-type personal injury.

Three years later, in Commissioner v. Schleier, ${ }^{62}$ the Court held that an award of back pay and liquidated damages under the Age Discrimination in Employment Act (ADEA) was not "on account of" a personal injury, and was thus not excluded from income, because neither remedy was given in lieu of - to compensate for - a personal injury. The award was given either to compensate for taxable income (lost wages) or as a statutory remedy without regard to whether or not the plaintiff suffered a personal injury.

In 1996, following these two highly-complex interpretations of the statutory language, the House of Representatives again proposed to limit the exclusion in IRC section 104(a)(2) to "physical injuries or physical sickness." According to the House Committee Report proposing to add the new "physical injury or physical sickness" language, the Committee believed that the change was needed because non-physical injury awards generally compensate for lost profits and wages that would otherwise have been taxable. The Committee felt that attempting to attribute the reason for the award (lost wages or lost personal enjoyment) has resulted in "substantial litigation, including two Supreme Court cases within the last four years." ${ }^{\prime 3}$ "The Committee concluded that "The taxation of damages received in cases not involving physical injury or physical sickness should not depend on the type of claim made." ${ }^{\text {"T }}$ The "physical" requirement, and the language saying that emotional injuries would not meet the "physical" requirement, were thus added to simplify the application of the rule.

In explaining the new physical injury requirement, the Committee focused on the origin of the claim and the proximity of the physical injury to the wrongful act:

If an action has its origin in a physical injury or physical sickness, then all damages (other than punitive damages) that flow therefrom are treated as payments received on account of physical injury or physical sickness whether or not the recipient of the damages is the injured party. ... The bill also specifically provides that emotional distress is not considered a physical injury or physical sickness. [footnote 24 deleted] Thus, the exclusion from gross income does not apply to any damages received (other than for medical expenses as discussed below) based on a claim of employment discrimination or injury to reputation accompanied

\footnotetext{
${ }^{61} 504$ U.S. 229 (1992).

${ }^{62} 515$ U.S. 323 (1995).

${ }^{63}$ House Committee Report on Small Business Job Protection Act of 1996, H.R. REP. No. 104- 586, at 143 (1996), 1996-3 C.B. 331, 481 ("Damages received on a claim not involving a physical injury or physical sickness are generally to compensate the claimant for lost profits or lost wages that would otherwise be included in taxable income. The confusion as to the tax treatment of damages received in cases not involving physical injury or physical sickness has led to substantial litigation, including two Supreme Court cases within the last four years. The taxation of damages received in cases not involving a physical injury or physical sickness should not depend on the type of claim made.").

${ }^{64} \mathrm{Id}$.
} 
by a claim of emotional distress. Because all damages received on account of physical injury or physical sickness are excludable from gross income, the exclusion from gross income applies to any damages received based on a claim of emotional distress that is attributable to a physical injury or physical sickness. ${ }^{65}$

In Footnote 24 of its report, the House Committee said "the Committee intends that the term emotional distress includes physical symptoms (e.g., insomnia, headaches, stomach disorders) which may result from such emotional distress." ${ }^{\text {"66 }}$ The House Committee that proposed adding the "physical" requirement thus specifically intended that physical manifestations of emotional distress not be treated as a "physical injury or physical sickness." There must be a proximate physical impact causing an immediate physical injury or sickness (although not necessarily to the plaintiff) in order to have a "physical injury or physical sickness" from which excludible damages could flow.

The Senate version of the bill eliminated the exclusion for all punitive damages, rather than just punitive damages arising out of non-physical injuries. However, the Senate's version did not accept the language proposed by the House of Representatives to eliminate the exclusion for all damages recovered for non-physical injuries, whether punitive, compensatory, or otherwise (other than the recovery of medical expenses). ${ }^{67}$

It is interesting to note that the change proposed by the Senate would have been rendered moot by the Supreme Court's later decision in O'Gilvie v. United States. ${ }^{68}$ The Court in O'Gilvie interpreted the pre-1996 statute to provide no exclusion for punitive damages, notwithstanding the specific language at the time limiting the exclusion only to punitive damages arising from non-physical injuries.

While, as in 1989, the Senate did not initially accept the House version of the bill, this time the Conference Committee agreed to the House version. ${ }^{69}$ The Conference Committee report quoted much of the language from the House Report concerning the reason for eliminating the exclusion for damages arising from emotional distress. ${ }^{70}$ The language limiting the exclusion to amounts received on account of "physical injuries or physical sickness," and providing that "emotional distress shall not be treated as a physical injury or physical sickness," became law. ${ }^{71}$ In his signing statement, President Clinton stated that he did not think damages for non-physical injury or sickness should be

\footnotetext{
${ }^{65} I d$. at 143-44 (emphasis added)

${ }^{66} I d$. (emphasis added).

${ }^{67}$ See S. REP. No. 104-281 at 97 (1996).

68519 U.S. 79 (1996).

69 See H.R. CONF. REP. No. 104-737 at 300 (1996), reprinted in 1996 U.S.C.C.A.N. 1677.

${ }^{70}$ Small Business Job Protection Act of 1996, Conference Report to accompany H.R. 3448, H.R. CONF. REP. 104-737, reprinted in 1996 U.S.C.C.A.N. 1677, 1996 W.L. 443734 at 265 (1996) ("The House bill also specifically provides that emotional distress is not considered a physical injury or physical sickness. Thus, the exclusion from gross income does not apply to any damages received (other than for medical expenses as discussed below) based on a claim of employment discrimination, or injury to reputation accompanied by a claim of emotional distress. Because all damages received on account of physical injury or physical sickness are excludable from gross income, the exclusion from gross income applies to any damages received based on a claim of emotional distress that is attributable to physical injury or physical sickness.").

${ }^{71}$ IRC $\$ 104(a)$ flush language, added by the Small Business Job Protection Act of 1996, Pub. L. No. 104188, 110 Stat. 1838 (1996).
} 
taxable, although he nevertheless signed the bill into law. ${ }^{72}$ Thus, the clear purpose of the new "physical injury or physical sickness" requirement was to make all amounts received for emotional distress damages, including amounts received on account of physical manifestations arising out of that emotional distress, includible in income.

The numerous other Courts that have addressed the physical injury limitations added by the 1996 amendments have recognized and applied the interpretation given by the legislative history, focusing on whether the settling party made the payment on account of a direct proximate physical injury or physical sickness (in which case there would be exclusion) or as a result of physical manifestations from emotional distress (in which case there would not be exclusion). ${ }^{73}$ The government has also issued an

\footnotetext{
${ }^{72}$ Statement by President William J. Clinton Upon Signing H.R. 3448, P. 3, 1996 U.S.C.C.A.N. 1862, 1996 W.L. 648447 (1996) ("Finally, I have reservations about a provision in the Act which makes civil damages based on nonphysical injury or illness taxable. Such damages are paid to compensate for injury, whether physical or not, and are designed to make victims whole, not to enrich them. These damages should not be considered a source of taxable income.").

${ }^{73}$ Lindsey v. Commissioner, 422 F.3d 684, 688-89 (8th Cir. 2005) (Business tort claim recoveries not excludible because taxpayer's "hypertension and stress-related symptoms, including periodic impotency, insomnia, fatigue, occasional indigestion, and urinary incontinence. . . relate to emotional distress, and not to physical sickness."); Johnson v. United States, 228 F. Supp. 2d 1218, 1224 n. 4 (D. Col. 2002) (“As discrimination is not a physical injury. Plaintiff's claim would also fail on this basis."); Goode v. Commissioner, T.C. Memo 2006-48 (T.C. 2006) (rejecting "physical injury" characterization in settlement agreement, and holding that employee's claimed "repeated, vehement verbal assaults . . . which caused him physical pain and suffering" did not constitute physical injury); Vincent v. Commissioner, T.C. Memo 2005-95 (rejecting physical injury characterization in settlement agreement); Ndirika v. Commissioner, T.C. Memo 2004-250 (No credible evidence employment settlement to compensate for previous miscarriage or pregnancy-related pain and suffering); Lindsey v. Commissioner, T.C. Memo 2004-113 (Hypertension leaving to "fatigability, occasional indigestion, and difficulty sleeping -- are the types of injuries or sicknesses that Congress intended to be encompassed within the definition of emotional distress."); Amos v. Commissioner, T.C. Memo 2003-329 (\$200,000 settlement payment to cameraman allegedly injured by Dennis Rodman at basketball gain was for "physical injury or sickness," because "Mr. Rodman's dominant reason in paying the settlement amount at issue was to compensate petitioner for his claimed physical injuries relating to the incident."); Venable v. Commissioner, T.C. Memo 2003-240, 24 (Malicious prosecution claim does not give rise to physical injury or sickness); Shaltz v. Commissioner, T.C. Memo 2003-173 (Sexual harassment settlement not excludible because no evidence of physical injury, only "depression, anxiety, stress, and recurrent past stressors" caused by "depression and trauma at work."); Henderson v. Commissioner, T.C. Memo 2003-168 (\$5,000 settlement of credit reporting claim not excludible even if "life-threatening, pre-existing physical illness" exacerbated by the harm to his personal reputation.”); Prasil v. Commissioner, T.C. Memo 2003-100 (Allegations of severe physical manifestations from sex discrimination and harassment not sufficient to establish physical injury or physical sickness); Witcher v. Commissioner, T.C. Memo 2002-292 (Physical manifestations caused by defamation and business torts not personal physical injury or physical sickness); Medina v. Commissioner, T.C. Summary Opinion 2003-148 (Settlement for wrongful termination due to pregnancy and resulting disability not excludible because wrongful termination did not cause physical sickness); Dorroh $v$. Commissioner, T.C. Summary Opinion 2003-93 (Petitioner's employment discrimination settlement not on account of personal physical injury suffered at work, which was covered by separate workers' compensation claim); Emanoil \& Magdalena Gantea v. Commissioner, T.C. Summary Opinion 2003-55 (settlement of injured employee's claim for invasion of privacy not "on account of" the physical injury); Nield v. Commissioner, T.C. Summary Opinion 2002-110 (No credible evidence that sex harassment recovery on account of physical injury or sickness. Court rejected petitioner's self-serving testimony that unwelcome touching (elbow to breast) led to physical injury (bruising), and also rejected new allegation that employer tackled petitioner in parking lot.); Reid v. Commissioner, T.C. Summary Opinion 2002-55 (Wrongful discharge recovery not on account of separate work-related injury covered by separate workers'
} 
administrative ruling concluding that there must be a contact resulting in "observable bodily harms such as bruises, cuts, swelling, and bleeding" to constitute a physical injury or physical sickness within the meaning of the statute. ${ }^{74}$ The court of appeals in Murphy did not cite to any of these many authorities.

It is a straightforward matter to apply Congress's intent in enacting the physical injury requirement, as explained in the legislative history, to Ms. Murphy's claim and award. Ms. Murphy had physical manifestations from her emotional distress, but did not suffer a physical injury - an impact - from which excludible damages could flow. The court of appeals thus reached the correct decision - that Ms. Murphy could not exclude her damages award under the statute, but it did so for the wrong reason. Ms. Murphy was not entitled to exclude the award because she did not suffer a "physical injury," since physical manifestations of emotional distress do not meet the statutory requirement. The court of appeals' use of the "in lieu of what" tracing requirement from O'Gilvie v. United States $^{75}$ to attempt to determine what the award was compensating for, ${ }^{76}$ and its improper focus on the language used in the heading of the award rather than the award's intent, ignored the intent of the 1996 amendment - as expressed in both the House and Conference Committee Reports - to avoid the kinds of difficult tracing distinctions suggested by the Court in Burke and Schleier for emotional injuries. Thus, whether or not the award was, in fact, made to compensate Ms. Murphy for her physical manifestations, and whether or not the Department of Labor hearing board adequately described the basis for the award, is now irrelevant under the statute. It is curious that the court of appeals in Murphy made no mention of the legislative history, because that history had been correctly analyzed in the district court's opinion in Murphy. ${ }^{77}$ Since Ms. Murphy's physical manifestations from her emotional injury did not constitute a "personal physical injury or physical sickness" within the meaning of the statute, she was not entitled to exclude the award.

\section{Without an Exclusion, Was Ms. Murphy Required to Include Her Award in} Gross Income?

Having properly determined, albeit for the wrong reasons, ${ }^{78}$ that Congress had not allowed Ms. Murphy to exclude her emotional distress award under IRC section

compensation case). See also Febray v. Commissioner, 223 F.3d 1261, 1262 n. 1 (11th Cir. 2000) (noting that physical injury requirement after 1996 amendments would have eliminated issue of excludability in case involving recovery on account of injury to business reputation.).

${ }^{74}$ Private Ltr. Rul. 200041022 (July 17, 2000) (unwelcome sexual harassment which included physical touching that did not result in observable bodily harm would not constitute an excludible "personal physical injury or sickness" within the meaning of IRC section 104(a)(2)).

75519 U.S. 79 (1996), discussed supra beginning at note 43.

${ }^{76}$ Murphy, 460 F.3d at 84.

${ }^{77}$ Murphy v Internal Revenue Service, 362 F. Supp. 2d 206, 215 (D.D.C. 2005), rev'd 460 F.3d 79 (D.C. Cir. 2006) ("Here, Murphy's mental anguish manifested into a physical problem, bruxism, but this was only a symptom of her emotional distress, not the source of her claim. Plaintiff's emotional distress is not "attributable to her physical injury; in fact, it is the other way around. Because the statute clearly provides damages must be received "on account of personal physical injury or physical sickness," and because mental pain and anguish and damage to reputation are not physical injuries, plaintiff's emotional distress damages are not included within the statutory exemption under $\S 104(a)(2)$.”).

${ }^{78}$ See supra Part III.C beginning at page 10. 
104(a)(2), the court of appeals proceeded to consider whether Congress had the constitutional power to tax the award. Reaching back to what it determined to be the meaning of "income" in 1913, when the 16th Amendment was enacted, the court of appeals held that Congress lacked the constitutional power to tax Ms. Murphy's award because it was not "income." The court of appeals then held that since Congress lacked the power to tax Ms. Murphy's award, IRC section 104(a)(2) must be unconstitutional.

The court of appeals missed an important step in its analysis - whether any provision of the IRC required Ms. Murphy's award to be included in income. Only amounts which must be included in income are statutorily subject to tax. IRC section 61 requires all "income" to be included in gross income and thereby made subject to taxation. Before considering whether the statute was constitutional, the court of appeals should have determined whether Congress required the award to be included in income under IRC section 61. If Congress lacked the power to tax Ms. Murphy's award, it would be the provision requiring the award to be included in income - IRC section 61 - that would be unconstitutional, not the exclusion provision.

By failing to address the inclusion question, the court of appeals missed an important and difficult legal question - whether an award could constitute "income" under IRC section 61 (a necessary predicate to considering the constitutional question), but not constitute income under the 16th Amendment, as the court of appeals ultimately held. The court of appeals failed to address this apparent conundrum.

As discussed below, using the modern theories of statutory interpretation adopted by the Supreme Court, the court of appeals could have properly reached the constitutional question by holding that Ms. Murphy's award was not "income" within the meaning of IRC section 61, notwithstanding any original meaning attached to section 61 or its predecessors by the original adopting Congresses. The court of appeals may have properly reached the constitutional question, but its flawed analysis led to holding the wrong statute unconstitutional for the wrong reason.

The court of appeals' specific holding in Murphy, that IRC section 104(a)(2) is unconstitutional, ${ }^{79}$ does not make logical sense. IRC Section 104(a)(2) is an exclusion provision, not an inclusion provision. ${ }^{80}$ The change made by Congress in 1996, to eliminate the exclusion for non-physical emotional distress damages recoveries, would only cause such damages to be taxable if, without regard to IRC Section 104(a)(2), such recoveries had to be included in income by some other provision. As currently written, IRC section 104(a)(2) excludes from income damages on account of physical injury or physical sickness, other than punitive damages. The court of appeals in Murphy was not questioning the constitutionality of the existing exclusion contained in IRC section 104(a)(2). Rather, it was questioning the constitutionality of Congress's attempt to affirmatively tax Ms. Murphy's compensatory non-physical injury recoveries. Therefore, it was not the exclusion in IRC section 104(a)(2) that would be unconstitutional, but

\footnotetext{
${ }^{79}$ Murphy, 460 F.3d at 92 ("insofar as $§ 104(a)(2)$ permits the taxation of compensation for personal injury, which compensation is unrelated to lost wages or earnings, that provision is unconstitutional.").

${ }^{80}$ IRC $\S 104(a)(2)$ ("gross income does not include ... (2) the amount of any damages (other than punitive damages) received (whether by suit or agreement and whether as lump sums or as periodic payments) on account of personal physical injuries or physical sickness."). The section says nothing about whether other awards, such as Ms. Murphy's award for non personal physical injury, are to be included in income.
} 
rather the provision requiring compensatory non-physical injury recoveries to be included in income that would be subject to constitutional attack.

The court of appeals in Murphy was wrong to hold IRC section 104(a)(2) unconstitutional. The Constitution does not require Congress to enact a specific exclusion for all of the things that do not constitute "income" or that cannot otherwise constitutionally be taxed. Rather, Congress has the affirmative duty to provide by statute what items are subject to its taxing laws.

Instead of focusing on the exclusion in IRC section 104(a)(2), the court of appeals in Murphy should have focused its attention on the inclusion provision in IRC section 61 - for taxpayers are only required to pay income taxes on amounts included in "gross income" under IRC section $61 .^{81}$ IRC section 61 provides:

Except as otherwise provided in this subtitle, gross income means all income from whatever source derived, including (but not limited to) the following [15] items: ${ }^{82}$

Thus, as a technical matter, Ms. Murphy's emotional distress and reputational damage award would only be included in gross income if the award constituted "income" within the meaning of IRC section 61.

The court of appeals in Murphy should have considered whether Ms. Murphy's award had to be included in income under the statute before considering whether the statute was constitutional. Under the established maxim that constitutional questions are to be avoided, ${ }^{83}$ a court can only reach a constitutional issue after first resolving the statutory issue. The court of appeals in Murphy failed to specifically address whether Congress had in fact statutorily required Ms. Murphy's damages award to be included in gross income, and thus subject to the income tax, before proceeding to the constitutional issue.

When it eliminated the exclusion in IRC section 104(a)(2), Congress clearly thought and intended that non-physical injury damages awards would be included in income under IRC section 61. Congress's intent to include in income emotional and other non-physical injury awards was made clear in the legislative history of the amendment. $^{84}$ More importantly, Congress's intent was also manifested by the enactment of the statute itself. There would be no logical reason for Congress to limit the exclusion in IRC section 104(a)(2) to "physical injuries and physical sickness," or to provide that emotional injuries would not constitute "physical injuries or physical sickness," if emotional and other non-physical injury recoveries were already excluded from taxation because they were not "income." If emotional injury recoveries were not included in "income" under IRC section 61, the amendment to IRC section 104(a)(2)

\footnotetext{
${ }^{81}$ IRC $\S 1$ imposes a tax on "taxable income." See IRC $\S \S 1$ (a) (married individuals filing jointly and surviving spouses); 1(b) (heads of households); 1(c) (unmarried individuals); 1(d) (married individuals filing separately); 1(e) (estates and trusts). "'[T] axable income' means gross income minus the deductions allowed by this chapter." IRC $\S 63$. Gross income is defined in IRC section 61 as "all income from whatever source derived." IRC $\S 61(\mathrm{a})$. Thus, unless an item is included in "gross income," it is not subject to tax under the IRC, and only items that constitute "income" are included in gross income.

${ }^{82}$ IRC $\S 61(a)$ (2006).

${ }^{83}$ See supra note 35.

${ }^{84}$ See discussion supra beginning at note 63 .
} 
would be a useless act. The doctrine of statutory interpretation known as the "rule against surplusage" requires Congressional acts to be interpreted to have meaning. ${ }^{85}$ Therefore, both the amendment to IRC section 104(a)(2) itself and the legislative history of the amendment show Congress's intent that emotional and other non-physical injury recoveries be included in income under IRC section 61.

On its face, the requirement to address the statutory issue before considering the constitutional issue would put the court of appeals in a conundrum. On the one hand, the court of appeals asserted that the word "income" has the same meaning in both the IRC and the 16th Amendment. ${ }^{86}$ The court of appeals appears to have made this assertion to support its argument that the government's early administrative rulings on the scope of the taxing statute should be read to limit Congress's power under the 16th Amendment. ${ }^{87}$ However, if the word "income" means the same thing under both the IRC and the 16th Amendment, then the Court could not find both that Ms. Murphy's damages award constituted "income" under the IRC (as it must to reach the constitutional question) while not constituting "income" within the meaning of the 16th Amendment (as it must to be unconstitutional). Rather than address the conundrum of Ms. Murphy's award constituting "income" under the IRC but not under the Constitution, the court of appeals focused on the elimination of the exclusion in IRC section 104(a)(2) as the unconstitutional act.

The solution to the conundrum is to recognize that that the word "income" in IRC section 61 has evolved from the time that the predecessors of section 61 were enacted in 1913. Regardless of the original meaning of the word income when IRC section 61 and its predecessors were enacted, Congress's intent at the time it amended IRC section 104(a)(2) in 1996 should prospectively ${ }^{88}$ control the interpretation of the ambiguous word "income" in IRC section 61.

${ }^{85}$ See William N. Eskridge, Jr., Philip P. Frickey and Elizabeth Garrett, Legislation and Statutory Interpretation, p. 266 (Foundation Press 2000) (referring to the doctrine as "The Rule Against Surplusage") (hereafter "Legislation and Statutory Interpretation").

${ }^{86}$ See supra note 18.

${ }^{87}$ Murphy, 460 F.3d at 88-90 ("Fortunately, we need not rely solely upon the wisdom and beneficence of the Congress, for, when the Sixteenth Amendment was drafted, the word "incomes" had well understood limits. ... We concur ... that the Attorney General's 1918 opinion and the Treasury Department's ruling of the same year strongly suggest that the term "incomes" as used in the Sixteenth Amendment does not extend to monies received solely in compensation for personal injury and unrelated to lost wages or earnings").

${ }^{88}$ The dynamic interpretation of statutory meaning discussed infra at note 91, applies only prospectively, because Congress generally legislates prospectively. See Untermyer v. Anderson, 276 U.S. 440, 445 (1928) (retroactive application of gift tax to gifts made before its enactment violates due process of law); Calder $v$. Bull, 3 U.S. 386, 390 (1798) (recognizing unjustness of retrospective laws); but see Petitioner v. Carlton, 512 U.S. 26 (1994) (validating explicit retroactivity provision in statute where government has a "legitimate purpose" for imposing a "modest period of retroactivity."). The corollary rule against retroactive legislative interpretations of earlier statutes has also been recognized by the Supreme Court. For example, in O'Gilvie v. United States, 519 U.S. 79 (1996), the taxpayer argued that Congress's 1989 amendment to section 104(a)(2), which eliminated an exclusion for "punitive damages not arising out of physical injury or physical sickness," implicitly recognized that the taxpayer's 1988 award of punitive damages arising out of a physical injury should be excluded from income. The Court rejected the taxpayer's argument because the taxpayer's settlement occurred and was governed by the statute in effect in 1988, before the 1989 amendment was made. The Court held that Congress's 1989 interpretation of a 1988 statute was irrelevant, because the meaning of the 1988 statute was governed by the interpretation of the earlier enacting Congress. The Court said "the view of a later Congress cannot control the 
Professors Eskridge, Frickey and Garrett, in their hornbook on statutory interpretation, have recognized that "[s]tatutory amendments can create new textual meaning as an indirect as well as a direct result of the new text that they add to the statutory scheme." ${ }^{, 9}$ This understanding of the dynamic nature of statutory construction - that the meaning of an earlier statute can be prospectively governed not by the intent of the original enacting Congress, but by the intent of a later Congress as expressed in an enactment or amendment to the statutory scheme, was recognized by the Court, including its three strictest constructionists, in Franklin v. Gwinnett County Public Schools. ${ }^{90}$ The facts of Franklin are somewhat complicated. In 1972, Congress enacted Title IX, which prohibited sex discrimination in many schools. ${ }^{91}$ In Cannon v. University of Chicago, ${ }^{92}$ the Supreme Court determined that private parties had an implied right of action under Title IX. In 1986, Congress amended Title IX to abrogate the sovereign immunity of state governments for private suits "to the same extent ... [as] any public or private entity other than a State." ${ }^{.93}$ In the 1986 amendments, Congress implicitly recognized the existence of a private right of action under Title IX, as had been determined by the 1979 Supreme Court decision in Cannon.

The issue in Franklin was whether a plaintiff, who had an implied private right of action under Cannon, could sue for damages or only back pay and prospective relief. The defendants argued that the original statute and legislative history did not specifically authorize damages recoveries, which is not surprising since the original statute did not expressly provide for a private right of action in the first place. The Supreme Court in Franklin first applied a general presumption that the courts would infer all available remedies when Congress establishes a private right of action. ${ }^{94}$ More importantly, the Supreme Court in Franklin then noted that subsequent statutory amendments in 1986 broadened the waiver of sovereign immunity, and did not restrict the remedy. The Court viewed these subsequent amendments as validating the Supreme Court's decision in Cannon that Congress intended a private right of action under Title IX, and also to show an intent not to limit the available remedy. ${ }^{95}$ The majority opinion thus recognized that the 1986 Congress's intent regarding the meaning of an earlier 1972 statute, as evidenced by statutory amendments made in 1986 to other related provisions, is effective to define the meaning of the 1972 statute.

Even more interesting is the concurrence in Franklin written by Justice Scalia for the three strictest constructionists then on the court - Justices Scalia, Rehnquist and

\footnotetext{
interpretation of an earlier enacted statute." In support of this rule, the Court cited two other cases holding that a Congressional interpretation of an earlier statute was not effective retroactively. United States $v$. Price, 361 U.S. 304, 331-32 (1960) ("the views of a subsequent Congress form a hazardous basis for inferring the intent of an earlier one."); Higgins v. Smith, 308 U.S. 473. 479-80 (1940) (Statute forbidding a certain deduction does not necessarily show that previous law would have authorized deduction.). These authorities do not address the prospective effect of a Congressional amendment that interprets a prior statute.

${ }^{89}$ Legislation and Statutory Interpretation, supra note 85 at 268.

90503 U.S. 60 (1992)

${ }^{91}$ Educational Amendments of 1972, Pub. L. No. 92-318, 86 Stat. 373 (codified, as amended, at 20 U.S.C. $\S 1681)$.

92441 U.S. 677 (1979),

${ }^{93}$ See 42 U.S.C. $\$ 2000 \mathrm{~d}-7$.

${ }^{94}$ Franklin, at 66.

${ }^{95}$ Franklin at 72-73.
} 
Thomas. The trio strongly disagreed both with the Court's prior decision in Cannon implying a private right of action under Title IX, and with the presumption in the majority opinion in Franklin that the broadest possible remedies should accompany an implied private right of action. ${ }^{96}$ Nevertheless, the strict constructionists concurred in the result because Congress, in the subsequent amendments to Title IX, had shown its intent to acquiesce in Cannon and to permit a damages remedy. As Justice Scalia stated:

The Rehabilitation Act Amendments of 1986, 42 U.S.C. $§$ 2000d-7(a)(2), must be read, in my view, not only "as a validation of Cannon's holding," but also as an implicit acknowledgment that damages are available. I therefore concur in the judgment. ${ }^{97}$

The entire Court thus recognized that later Congressional amendments to one statute can be effective in prospectively defining the meaning of another earlier provision of the same statutory scheme.

This dynamic approach to statutory construction makes good sense, because Congress had the power to amend the original statute. It did not amend the original statute because it did not know that an amendment would be necessary. Because it had the power to amend the original statute, Congress's interpretation of the meaning of the original statute in an enacted amendment should be effective as a legislative act that prospectively defines the earlier statute's meaning. In a sense, by amending one part of a legislative scheme, the later Congress is reenacting the remaining parts of the scheme, and these remaining parts should therefore be governed by the new Congress's intent as expressed in the statutory amendment. ${ }^{98}$

Professors Eskridge, Frickey and Garrett have recognized that the rule of implied statutory amendments can conflict with the rule against implied repeals of un-amended earlier statutes if the earlier statute had a clear meaning, and was not itself amended. The rule against implied repeals protects against inferring an intent to Congress's inaction that is counter-intuitive - for if Congress intended to change the meaning of a clear statute, it could easily amend the statute. Professors Eskridge, Frickey and Garret conclude that "The rule against implied repeals should be limited to cases where the earlier statute had a relatively clear and longstanding meaning and the later statute is ambiguous enough to have a neutral interpreter pause." 99 The rule against implied repeals should not apply to ambiguous statutes, because Congress would not know of the need to make the amendment. Instead of protecting congressional intent from wrongful judicial inferences,

\footnotetext{
${ }^{96}$ Franklin, at 77-78 (Scalia, J., concurring).

${ }^{97}$ Id. at 78 (Scalia, J., concurring) (citations omitted).

98 This doctrine is similar to the so-called "reenactment rule," under which the Courts presume that Congress intended to adopt an extant judicial interpretation of a statute when it reenacts the statute without changing it to negate the judicial interpretation. See e.g. United States v. Board of Comm'rs of Sheffield, Ala., 435 U.S. 110 (1978); United States v. Cerecedo Hermanos y Compania, 209 U.S. 337, 339 (1908). In effect, Congress re-enacted the earlier statute at the time it enacted the later statutory or amendment that interpreted the earlier statute. Professors Eskridge, Frickey and Garrett have recognized that, "[s]o long as it follows the Article I, Section 7 procedures, each Congress can not only enact statutes, but can amend or repeal statutes adopted by earlier Congresses. This idea could also justify the Court's dynamic interpretation of statutes in both Sweet Home and Franklin, where subsequent amendments arguably changed the proper interpretation of provisions that were not formally amended." Legislation and Statutory Interpretation, supra note 85 at 274.

${ }^{99}$ Legislation and Statutory Interpretation, supra note 85, at 274 n. 61.
} 
applying the rule against implied repeals to ambiguous statutes would ignore clear congressional intent. Therefore, as a matter of statutory construction, Congress's intent regarding the meaning of ambiguous corollary statutes is governed prospectively by Congress's intent at the time the statutory scheme is changed.

The same analysis that was recognized by the Court in Franklin should apply in Murphy. Congress intended emotional and other non-physical damages recoveries to be included in "income" under IRC section 61 when it amended IRC section 104(a)(2) to eliminate the exclusion. This was clear both from the legislative history, which specifically discussed the reason for requiring emotional injury recoveries to be included in income, ${ }^{100}$ and from the intent manifest in the statutory amendment itself. ${ }^{101}$ Therefore, both the amendment to IRC section 104(a)(2) itself and the legislative history of the amendment show Congress's intent that emotional and other non-physical injury recoveries be included in income under IRC section 61 .

Because Congress clearly intended in its amendment to IRC section 104(a)(2) in 1996 for non-physical injury recoveries be included in income, that intent should govern the meaning of the ambiguous term in section 61 prospectively. The courts would be ignoring the will of a Congress that had the power and intent to require Ms. Murphy's to include her emotional distress damages recovery in income if they held that the her award was not "income" within the historic meaning of IRC $\S 61$. The courts should therefore accept the meaning of IRC section 61 that Congress intended when it amended the statutory scheme in 1996 - to require Ms. Murphy to include her emotional and reputational damages award in income.

Therefore, the court of appeals in Murphy should have held that Ms. Murphy's award constituted "income" under IRC section 61 because of Congress's manifested intent when it amended IRC section 104(a)(2) in 1996. The court of appeals should also have recognized that the word "income" in IRC section 61, as interpreted by Congress in the 1996 amendment to IRC section 104(a)(2), may not mean the same thing as "income" under the 16th Amendment. Only by recognizing a distinction between the meaning of the word "income" under the statute and the constitutional amendment could the court properly consider the constitutional issue. The court of appeals erred in holding the exclusion contained in IRC section 104(a)(2) unconstitutional rather than focusing on the inclusion required by IRC section 61 . However, the court of appeals correctly concluded that Ms. Murphy's award was statutorily taxable, and therefore it was proper for the court of appeals to consider whether the statute was constitutional.

\section{The Constitutional Questions.}

\section{A. Congress Had the Power to Tax Ms. Murphy's Damages Award Without the 16th Amendment.}

The court of appeals in Murphy began its constitutional analysis by stating that "[t]he constitutional power of the Congress to tax income is provided in the Sixteenth

\footnotetext{
${ }^{100}$ See discussion supra beginning at note 84

${ }^{101}$ See discussion supra in the paragraph following note 84 .
} 
Amendment, ratified in 1913." ${ }^{\prime 102}$ This is an erroneous statement of law, and demonstrates a serious misunderstanding of income tax history.

It is true that Congress has those powers, and only those powers, authorized by the Constitution. In recognizing the power of judicial review, the Supreme Court in the famous case of Marbury v. Madison said "The powers of the legislature are defined and limited; and that those limits may not be mistaken or forgotten, the constitution is written." ${ }^{103}$ Therefore, every act of Congress must be permitted explicitly or implicitly by the Constitution. There is a strong presumption that congressional statutes are constitutional, and that presumption is only to be overcome "upon a plain showing that Congress has exceeded its constitutional bounds."104

However, a court cannot declare a law unconstitutional merely because one provision of the Constitution does not authorize the law if there is another provision in the Constitution that does authorize it. The proper constitutional question is whether Congress had the power under any provision of the constitution to tax Ms. Murphy's emotional and reputational damage award. In order to determine whether the Constitution gives to Congress the power to enact a law, "[i]t is, therefore, necessary to search the Constitution to ascertain whether or not the power is conferred."105 "The burden is on the one attacking the legislative arrangement to negative every conceivable basis which might support it."106

Even if the court of appeals was correct when it held that Ms. Murphy's emotional and reputational damages award was not "income" within the meaning of the 16th Amendment, a holding that is questioned below, ${ }^{107}$ the court of appeals in Murphy should have considered whether other provisions of the Constitution would permit Congress to tax the award.

A proper historical review of Congress's taxing power reveals that Congress had the constitutional power to tax Ms. Murphy's damages award even if it was not "income" within the meaning of the 16th Amendment. Congress's constitutional power to both tax property transactions and human capital had long been recognized before the 16th Amendment was adopted and has never seriously been questioned. The court of appeals' statement, that Congress's power to tax income derives from the 16th Amendment, shows a great misunderstanding of both the Constitution and the judicial history of income taxation. What follows is a thorough-going review of tax history which will demonstrate the error made by the court of appeals in Murphy in focusing solely on the 16th Amendment.

\footnotetext{
${ }^{102}$ Murphy, 460 F.3d at 84-85.

1035 U.S. 137, 176 (1803), quoted in United States v. Morrison, 529 U.S. 598, 607 (2000).

${ }^{104}$ United States v. Morrison, 529 U.S. 598, 607 (2000) ("Due respect for the decisions of a coordinate branch of Government demands that we invalidate a congressional enactment only upon a plain showing that Congress has exceeded its constitutional bounds. ... With this presumption of constitutionality in mind. ...") (citations omitted). Morrison was cited with approval in Murphy, 460 F.3d at 84.

${ }^{105}$ United States v. Harris, 106 U.S. 629, 636 (1883), overruled on other grounds, Chimel v. California, 395 U.S. 752 (1969). This discussion in Harris was cited with approval in United States v. Morrison, 329 U.S. at 607.

${ }^{106}$ Madden v. Kentucky, 309 U.S. 83, 87-88 (1940) (footnotes omitted), quoted with approval in Regan v. Taxation with Representation, 461 U.S. 540, 547 (1983).

${ }^{107}$ See discussion infra in Part IV.B beginning at page 46.
} 
Although the court of appeals in Murphy contended otherwise, ${ }^{108}$ Congress's power to impose income taxes does not derive from the 16th Amendment. Rather, it derives from the plenary power given to Congress in Article I of the Constitution to impose all forms of taxation, other than taxes on exports. ${ }^{109}$ The Constitution contains two provisions restricting the manner in which Congress can exercise its plenary power of taxation. The first provision requires that "duties, imposts and excises" be uniform:

"Congress shall have Power to lay and collect Taxes, Duties, Imposts and Excises . . . but all Duties, Imposts and Excises shall be uniform throughout the United States."110

The uniformity requirement has long been interpreted to require only that the tax law not discriminate geographically. ${ }^{111}$

The second restriction, and the more important one for this paper, requires that capitation and direct taxes be apportioned. The apportionment requirement was contained in two clauses: "No capitation, or other direct, Tax shall be laid, unless in Proportion to the Census or Enumeration herein before directed to be taken"112 and "Representatives and direct taxes shall be apportioned among the several states."113

It is difficult to administer an apportioned tax other than capitation taxes. ${ }^{114}$ Apportionment requires that the share of the total federal tax liability paid by the citizens of each state be proportional to the relative population of each state. ${ }^{115}$ Apportionment generally requires a two-step approach, in which each state's share of the total revenue

\footnotetext{
${ }^{108}$ Murphy, 460 F.3d at 84 ("The constitutional power of the Congress to tax income is provided by the Sixteenth Amendment, ratified in 1913."). No citation followed this statement.

${ }^{109}$ See e.g. Brushaber v. Union P. R. Co., 240 U.S. 1 (1916); Stanton v. Baltic Mining Co., 240 US 103 (1916).

${ }^{110}$ U.S. CONST. art I, $\$ 8$, cl. 1.

${ }^{111}$ See Knowlton v. Moore, 178 U.S. 41 (1900) (inheritance tax - geographical uniformity); United States $v$. Singer, 15 Wall. 111, 121 (1872) (distillary tax - geographical uniformity and no discrimination between distillers).

${ }^{112}$ U.S. CONST. art. I, $\S 9$.

${ }^{113}$ U.S. CONST. art. I, §.2, cl. 3.

${ }^{114}$ See Erik M. Jensen, Interpreting the Sixteenth Amendment (By Way of the Direct-Tax Clauses), 21 CONST. COMMENTARY 355, 356 (2004) ("Everyone agrees that apportionment makes direct taxes very difficult to implement"). Apportionment is difficult to implement because, except for head taxes, a flat tax imposed on an item of property that is held in each state in proportionate numbers to population, or a tax imposed on the value of property in which the value of such property in each state is proportionate to population, the rates of taxes imposed on the same property held in different states will differ. Congress did impose apportioned property taxes in the 19th Century, but the last such apportioned tax was imposed during the Civil War in 1861. Id. at 356, citing Act of Aug. 5, 1861, ch. 45, 12 Stat. 292.

${ }^{115}$ For example, if New York has $10 \%$ of the population, then the share of the total tax paid by New York's citizens can be no more than $10 \%$ of the total tax. Jensen, supra note 114 , at 358 . It is very difficult to impose an apportioned tax other than a head tax. A flat and uniform head tax would be automatically apportioned because, since the base is population, the tax imposed in each state would automatically be proportionate to population. Except in very unlikely scenarios (see supra note 114), any other tax requires a two step process of determining the amount to be borne by the citizens of each state according to population, and then assessing the citizens of each state at different rates to collect the appropriate tax shares of the tax.
} 
desired is first allocated according to state population, and then the tax rates for the citizens of each state are set. The result will almost always be different rates of tax in each state, because the tax base in each state will not be proportional to population.

The apportionment requirement for direct taxes arose out of the debate over whether slaves would be counted in the state's population for determining the number of representatives each state would have in the House of Representatives. Gouverneur Morris said that Pennsylvania "will never agree to a representation of Negroes," 116 and Mr. Davie, in turn, said that North Carolina would never confederate on any terms that did not rate them [slaves] at least as 3/5."117 Professor Bruce Ackerman explained how the great compromise over taxation, representation and slavery was reached: ${ }^{118}$

As the Convention struggled to avoid dissolution, Gouverneur Morris took the first constructive step: If the South insisted upon extra representation for its slaves, why not require it to pay a price at tax time? On Thursday, July 12, he moved that "taxation shall be in proportion to Representation." ${ }^{119}$ However, after a discussion recognizing the administrative difficulty of apportioning all taxes, Gouverneur Morris amended his proposal to limit the apportionment requirement to direct taxes. ${ }^{120}$

There was, however, no discussion at the convention as to the precise meaning of the term "direct taxes." 121 Professor Bruce Ackerman believes that any attempt to define the term would have been "picking at a sore wound" and that the delegates thought it better to leave the definition to the future. ${ }^{122}$

Except for taxes on exports which was strictly forbidden, these two limitations uniformity for duties, imposts and excises, and apportionment for direct taxes - are the only specific restrictions contained in the Constitution on Congress's power to tax. Both are procedural restrictions on the method used to impose taxes, not substantive limitations on Congress's power to impose taxes. ${ }^{123}$ However, because in practice it would be so difficult to administer and politically justify an apportioned tax, the procedural restriction of apportionment would likely prevent Congress from imposing

\footnotetext{
1161 The Records of the Federal Convention of 1787, at 523 (Max Farrand ed., Yale Univ. Press, 1966) (July 12, 1787) [hereinafter "Records"], quoted in Bruce Ackerman, Taxation and the Constitution, 99 ColuM. L. REV. 1, 9 (1999) (hereafter, “Ackerman”).

${ }^{117}$ Records, supra note 116, at 593 (July 12, 1787), quoted in Ackerman, supra note 116, at n. 27.

118 Ackerman, supra note 116, at 9.

${ }^{119}$ Records, supra note 116, at 592 (July 12, 1787), quoted in Ackerman, supra note 116, at n. 28.

${ }^{120}$ Records, supra note 116, at 593 (July 12, 1787), quoted in Ackerman, supra note 116, at n.34.

121 "Mr King asked what was the precise meaning of direct taxation? No one answered." 2 Records, supra note 116, at 350 (Aug. 20, 1787), quoted in Ackerman, supra note 116, at n. 39.

122 Ackerman, supra note 116 , at 11 .

${ }^{123}$ This has long and repeatedly been held by the Courts. See e.g. Veazie Bank v. Fenno, 75 U.S. 533 (1869); Brushaber v. Union P. R. Co., 240 U.S. 1 (1916); Stanton v. Baltic Mining Co., 240 US 103 (1916). These are not strictly limitations of power. They are rules prescribing the permissible ways in which the power can be exercised.
} 
direct taxes in many circumstances. ${ }^{124}$ Thus, it is important to determine the meaning of "direct taxes" in order to determine the constitutionality of an unapportioned tax.

\section{(2) Early Judicial Interpretations of the Direct Taxing Clause.}

The meaning of "direct tax" has been the subject of debate in the Courts for more than 200 years, ${ }^{125}$ and remains a source of debate within the academy today. ${ }^{126}$ While there are many conflicting theories about the word's original meaning to the drafters, adopters and ratifiers of the constitution, ${ }^{127}$ the following discussion focuses on judicial interpretations rather than on historical speculations. A careful review of the historical development will demonstrate the Murphy court's error in assuming that Congress's power to tax an emotional injury award derives solely from the 16th Amendment of the Constitution, and in holding that the tax is unconstitutional because it is not within the Amendment's embrace. Indeed, the following discussion will show that even without the 16th Amendment, Congress would have the constitutional power to impose a uniform tax on personal injury awards and settlements such as the one obtained by Ms. Murphy. The Murphy court's speculation that a compensatory award is not within the 16th Amendment - a very questionable conclusion based on dubious evidence ${ }^{128}-$ is irrelevant if Congress had the Constitutional power to tax the award outside of the 16th Amendment.

The first great tax case to consider the direct taxing clause was decided by the United States Supreme Court in 1796. In 1794, Congress passed a tax on "carriages for the conveyance of persons, varying from \$1 to \$10." 129 Daniel Hylton, who claimed to own 125 carriages for his own personal use, was fined when he failed to pay the tax, ${ }^{130}$ Although the procedural history is dim, Mr. Hylton's challenge to the tax was heard by the United States Supreme Court. Mr. Hylton claimed that the carriage tax was an unconstitutional unapportioned direct tax. ${ }^{131}$

\footnotetext{
${ }^{124}$ See Calvin Johnson, Fixing the Constitutional Absurdity of the Apportionment of Direct Tax, 21 CONST. COMMENTARY 295 (2004); Calvin Johnson, Apportionment of Direct Taxes: The Foul-Up in the Core of The Constitution, 7 WM. \& MARY BILL RTS. J. 1 (1998).

${ }^{125}$ Compare Hylton v. United States, 3 U.S. 171, 172 (1796) (direct taxes are taxes that can be easily apportioned); Pollock v. Farmers' Loan \& Trust Co. (Pollock I), 157 US 429 (1895) (tax on income from real property is direct tax that must be apportioned); Pollock v. Farmers' Loan \& Trust Co. (Pollock II), 158 US 601 (1895) (tax on income from personal property is direct tax that must be apportioned); .

Stanton v. Baltic Mining Co., 240 US 103 (1916) (calling Pollock's theory, that taxes on income from property must be apportioned, "erroneous").

${ }^{126}$ Compare articles by Calvin Johnson, supra note 124 (arguing for the adoption of the theory utilized in Hylton v. United States, 3 U.S. 171 (1796)), with Erik M. Jensen, Interpreting the Sixteenth Amendment (By Way of the Direct-Tax Clauses), 21 CONST. COMMENTARY 355 (2004) (Arguing that "the universe of taxes potentially subject to apportionment isn't trivial. These taxes probably include, for example, a wealth tax and a direct-consumption tax.").

${ }^{127}$ See e.g. Ackerman, supra note 116, at 16-20 (discussing the Physiocratic theory, then prevalent, that all wealth derives from land), the articles by Professor Calvin Johnson, supra, note 124 (apportionment derived from requisitions, and covered only taxes that were intended to be imposed like requisitions in an apportioned way); and Professor Erik M. Jensen, infra note 132 (direct taxes had broader meaning).

${ }^{128}$ See discussion infra at Part IV.B beginning at page 36.

${ }^{129}$ Act of June 5, 1794, ch. 45, 1, 1 Stat. 373, 374 (repealed 1802); See also Hylton v. United States, 3 U.S. 171,172 (1796).

${ }^{130} I d$

${ }^{131} \mathrm{Id}$.
} 
Professor Erik M. Jenson has argued that the case was set-up by anti-federalists seeking to challenge the government's taxing authority. ${ }^{132}$ In order to meet the jurisdictional requirements, Mr. Hylton claimed to own 175 chariots "for his own separate use, and not to let out to hire, or for the conveyance of persons for hire" $" 133$ more than existed at the time, according to one early commentator, in the entire State of Virginia. ${ }^{134}$ Professor Jensen claims that the jurisdictional defects were overlooked by a federalist bench seeking to establish Congress's broad taxing power. ${ }^{135}$ Alexander Hamilton, then the former Secretary of the Treasury and the spiritual leader of the federalists, personally argued before the Supreme Court that the tax should be upheld. ${ }^{136}$ The case was heard before the principal of judicial review had been established ${ }^{137}$ by four Supreme Court justices, three of whom issued substantive separate opinions.

All of the justices agreed that the carriage tax was not a direct tax requiring apportionment. They differed in dicta about the meaning of direct taxes. Justice Chase accepted Alexander Hamilton's argument that direct taxes are only those that can be reasonably apportioned, and also stated that the tax could be justified as an indirect tax on an expense. This expense theory was better developed by Justice Patterson. In dicta, Justice Chase also stated his opinion, emphasizing that it was not a judicial opinion, that there are only two kinds of direct taxes "to wit, a capitation, or poll tax, simply, without regard to property, profession, or any other circumstances; and a tax on LAND. -- I doubt whether a tax, by a general assessment of personal property, within the United States, is included within the term direct tax." 138

Justice Patterson held "I never entertained a doubt, that the principal, I will not say, the only, objects, that the framers of the Constitution contemplated as falling within the rule of apportionment, were a capitation tax and a tax on land."139 Justice Patterson explained that the purpose of the direct taxing clause was to protect the southern states whose citizens owned large tracts of low-value undeveloped land from being taxed on their land at the same per acre rates as the citizens of northern states who had smaller tracts of high-value developed lands. ${ }^{140}$ Justice Patterson also suggested a theoretical

\footnotetext{
132 See Erik M. Jensen, The Apportionment of "Direct Taxes": Are Consumption Taxes Constitutional?, 97 ColuM. L. REV. 2334, 2352 (1997).

${ }^{133}$ Hylton, 3 U.S. at 176 (Patterson, J.).

${ }^{134}$ See Id., quoting Edward B. Whitney, The Income Tax and the Constitution, 20 HARV. L. REV. 280,283 n.1 (1907).

${ }^{135} I d$.

${ }^{136} \mathrm{Id}$. at 171 .

${ }^{137}$ The Supreme Court established the principal of judicial review - that the Supreme Court had the constitutional authority to declare acts of the legislative and executive branches, and acts by state legislatures, to be unconstitutional - seven years later in Marbury v. Madison, 5 U.S. 137 (1803). Justice Chase stated in Hylton: "As I do not think the tax on carriages is a direct tax, it is unnecessary, at this time, for me to determine, whether this court, constitutionally possesses the power to declare an act of Congress void, on the ground of its being made contrary to, and in violation of, the Constitution; but if the court have such power, I am free to declare, that I will never exercise it, but in a very clear case." Hylton, 5 U.S. at 175. Professor Jensen argues that the case would have been moot if the Supreme Court did not have the power of judicial review, and thus the power must have been assumed to exist for jurisdiction to exist. See Jenson, The Apportionment of “Direct Taxes, ” supra note 132, at 2352 n. 95.

${ }^{138} \mathrm{Id}$. at 558 .

${ }^{139}$ Id. at 177 (Patterson, J.)

${ }^{140} I d$. ("The provision was made in favor of the southern States. They possessed a large number of slaves; they had extensive tracts of territory, thinly settled, and not very productive. A majority of the states had
} 
distinction between direct and indirect taxes. Quoting from Adam Smith's The Wealth of Nations, Justice Patterson argued that taxes imposed on expenses or consumption, such as the portion of the carriage that is used up during the year, are indirect because they are a circuitous method of taxing income. ${ }^{141}$ Presumably, this is also what Justice Chase was referring to when he justified the Carriage Tax as a tax on an expense. ${ }^{142}$

Justice Iredell thought that only those taxes that could be apportioned without creating unfair results within different states should be considered direct. ${ }^{143}$ He noted that an apportioned tax on carriages would require owners in one state to pay a higher tax than owners in another state because carriage ownership was not proportional to state population. ${ }^{144}$ Thus, an apportioned carriage tax, he believed, would generate the absurd result of differing taxation depending on the taxpayer's state of residence. In addition, Congress could not impose an apportioned carriage tax if there existed any state without carriages, because there would be no way for that state's residents to pay their share of the total tax in proportion to population. Justice Iredell thought it better not to attempt to define direct taxes since only a carriage tax was before the Court. ${ }^{145}$ Nevertheless, he suggested that direct taxes might refer only to taxes on land or a product of land something that is fixed and present in every state. ${ }^{146}$

Justice Wilson wrote a two sentence opinion agreeing that the tax on carriages was constitutional. ${ }^{147}$ Justice Cushing dissented because he had not participated in the hearing of the case, and therefore could not render an opinion on it. ${ }^{148}$

It is difficult to glean a clear rule from Hylton, other than the precise holding that a flat tax on carriages was held to be an indirect tax that did not need to be apportioned.

but few slaves, and several of them a limited territory, well settled, and in a high state of cultivation. The southern states, if no provision had been introduced in the Constitution, would have been wholly at the mercy of the other states. Congress in such case, might tax slaves, at discretion or arbitrarily, and land in every part of the Union after the same rate or measure: so much a head in the first instance, and so much an acre in the second. To guard them against imposition in these particulars, was the reason of introducing the clause to the Constitution, which directs that representatives and direct taxes shall be apportioned among the states, according to their respective numbers.").

${ }^{141} I d$. at 180 ("All taxes on expenses or consumption are indirect taxes. A tax on carriages is of this kind, and of course is not a direct tax. Indirect taxes are circuitous modes of reaching the revenue of individuals, who generally live according to their income.")

${ }^{142}$ See quotation from Justice Chase, supra, at note 138.

${ }^{143} \mathrm{Id}$. at 561 (Iredell, J.) ("As all direct taxes must be apportioned, it is evident that the Constitution contemplated none as direct but such as could be apportioned. If this cannot be apportioned, it is, therefore, not a direct tax in the sense of the Constitution.").

${ }^{144}$ Justice Iredell gave a hypothetical under which the residents of Virginia would pay $\$ 3.80$ per carriage while the residents of Connecticut would pay $\$ 35$ per carriage; a result that Justice Iredell thought would be absurd. Id. at 182 .

${ }^{145} \mathrm{Id}$. at 183 ("There is no necessity, or propriety, in determining what is or is not, a direct, or indirect, tax in all cases. Some difficulties may occur which we do not at present foresee.").

${ }^{146} I d$. ("Perhaps a direct tax in the sense of the Constitution, can mean nothing but a tax on something inseparably annexed to the soil: Something capable of apportionment under all such circumstances. A land or a poll tax may be considered of this description. . . In regard to other articles, there may possibly be considerable doubt. It is sufficient, on the present occasion, for the court to be satisfied, that this is not a direct tax contemplated by the Constitution, in order to affirm the present judgment; since, if it cannot be apportioned, it must necessarily be uniform.").

${ }^{147} I d$. at 183 (Wilson, J.).

${ }^{148} I d$. at 184 (Cushing, J., dissenting). 
However, the majority of the judges suggested that only land or capitation taxes, or something very similar, would be considered direct.

Modern commentators strongly disagree about the precedental effect that Hylton should have. One camp, exemplified by Professor Calvin Johnson, gives great weight to the interpretation made by justices who were members of the founding generation, some of whom even participated in the negotiations that led to the direct taxing clause. ${ }^{149}$ The other camp, exemplified by Professor Erik Jensen, view Hylton as a phony political opinion lacking a balanced analytical framework. ${ }^{150}$

The next case to be heard by the Supreme Court considered the constitutionality of the first federal income tax, which was imposed during the civil war. ${ }^{151}$ In Pacific Insurance Company v. Soule, ${ }^{152}$ the Court considered two issues. The first issue was whether the tax on an insurance company's income that had been received in coined money could be computed and paid in depreciated legal tender currency, or whether the additional value of coined money over the depreciated currency was also "income." After reviewing the taxing act, which required a separate accounting for income received in coin and currency, the Court held that additional income was reportable when income was received in coin and the tax paid in currency. ${ }^{153}$ The second question considered by the Court was whether the income tax was a direct tax that failed to comply with the rules of apportionment. The Court followed the theory expressed in Hylton that only taxes that could be easily and fairly apportioned would be direct. Applying this theory to the tax on an insurance company's income, the Court said:

The consequences which would follow the apportionment of the tax in question ... must not be overlooked. They are very obvious. Where such corporations are numerous and rich, it might be light; where none exist, it could not be collected; where they are few and poor, it would fall upon them with such weight as to involve annihilation. It cannot be supposed that the framers of the Constitution intended that any tax should be apportioned, the collection of which

\footnotetext{
${ }^{149}$ See Calvin Johnson, Fixing the Constitutional Absurdity of the Apportionment of Direct Tax, supra note 124, at 332 (calling Hylton "heroic" and arguing for a return to its theory); Calvin Johnson, Apportionment of Direct Taxes, supra note 124, at 75 (Arguing at length that "Hylton has a special legitimacy on both its holding and its functional perspective on constitutional construction, because of who the actors were."); Marjorie E. Kornhauser, The Constitutional Meaning of Income and the Income Taxation of Gifts, 25 CONN. L. REV. 1, 22 (1992) (arguing for special weight to be given to the Hylton decisions because of the closeness in time to the adoption of the Constitution and the participation of the judges in the constitutional process).

${ }^{150}$ See Jensen, Interpreting the 16th Amendment, supra note 114, at 379-380 (noting, among other things, that the judges had fewer reference works than we have today, failed to cite primary sources, were all wellknown federalists who had an agenda to expand governmental power); Jensen, The Apportionment of Direct Taxes, supra note 114, at 2356-57 (criticizing Alexander Hamilton for advancing positions inconsistent with his prior writings regarding the meaning of the direct taxing clause, and criticizing the judges for their lack of analysis).

${ }_{151}$ The Civil War income taxes were imposed by the Internal Revenue Act of June 30, 1864, and amended by the Internal Revenue Act of July 13, 1866, 13 Stat. 105, 120, pp. 276, 283.

15274 U.S. 433 (1869).

${ }^{153} I d$. at $442-43$.
} 
on that principle would be attended with such results. The consequences are fatal to the proposition. ... [t] he tax [in issue] is not a direct tax, but a duty or excise; that it was obligatory on the plaintiff to pay it.

Shortly thereafter, in Veazie Bank v. Fenno, ${ }^{154}$ a $10 \%$ tax on the issuance by a state or national banking association of bank notes was upheld against constitutional challenge. Justice Chase pointed out that Congress had only previously adopted apportioned taxes on real property and slaves, and that "taxes on personal property, contracts, occupations, and the like, have never been regarded by Congress as proper subjects of direct tax." therefore, that in the practical construction of the Constitution by Congress, direct taxes have been limited to taxes on land and appurtenances, and taxes on polls, or capitation taxes." "156 After reviewing James Madison's notes from the constitutional convention, Justice Chase concluded "All this ... indicates, also, an understanding that direct taxes were such as may be levied by capitation, and on lands and appurtenances; or, perhaps, by valuation and assessment of personal property upon general lists."157 Finally, after reviewing the Court's early holding in Hylton, and recent holding in Soule, Justice Chase concluded that only taxes on land, capitation, polls, and possibly personal property upon general lists would be considered direct, and therefore it "follows necessarily that the power to tax without apportionment extends to all other objects." 158

Next, in Scholey v. Rew, ${ }^{159}$ the Supreme Court upheld a Civil War succession tax, which applied to the real estate Mr. Scholey received under the will of his deceased wife. The Court held that the tax was an excise on the transfer of property, not a tax on the real estate itself. Interestingly, the Court also compared the succession tax to an income tax:

Taxes on lands, houses, and other permanent real estate have always been deemed to be direct taxes, and capitation taxes, by the express words of the Constitution, are within the same category, but it never has been decided that any other legal exactions for the support of the Federal government fall within the condition. ... Whether direct taxes in the sense of the Constitution comprehend any other tax than a capitation tax and a tax on land is a question not absolutely decided, nor is it necessary to determine it in the present case, as it is expressly decided that the term does not include the tax on income, which cannot be distinguished in principle from a succession tax such as the one involved in the present controversy. ${ }^{160}$

\footnotetext{
15475 U.S. 533 (1869).

${ }^{155} I d$. at 543. Justice Chase explained that the taxation of slaves was in a special class, and that slaves were treated for purposes of taxation as a form of real estate. Id.

${ }^{156} I d$.

${ }^{157}$ Id. at 544 .

${ }^{158} \mathrm{Id}$. at $546-47$.

${ }^{159} 90$ U.S. 331 (1875).

${ }^{160} \mathrm{Id}$. at 347 (citations omitted, emphasis added).
} 
The Civil War income tax was challenged by an individual many years after its enactment and repeal in Springer $v$. United States, ${ }^{161}$ and was again upheld. The taxpayer in Springer filed an income tax return, but refused to pay the assessed tax. The tax collector therefore levied on the taxpayer's real estate, purchased the property at a tax lien sale, and sought to eject the taxpayer from the premises. The taxpayer then challenged the tax assessment, levy, sale, and ejectment on due process and apportionment grounds. Once again, the Supreme Court upheld the validity of the tax from constitutional challenge, relying on the lack of clarity from the constitutional debates, ${ }^{162}$ the notes left behind by Alexander Hamilton from the Hylton case, ${ }^{163}$ the letters of James Madison disagreeing with the Hylton case but recognizing that the courts were unlikely to adopt his views, ${ }^{164}$ the prior practice of Congress in imposing taxes, ${ }^{165}$ and the recent decisions in Veazie, Soule and Scholey. ${ }^{166}$ The Court concluded: "that direct taxes, within the meaning of the Constitution, are only capitation taxes, as expressed in that instrument, and taxes on real estate; and that the tax of which the plaintiff in error complains is within the category of an excise or duty." 167

The early courts had thus interpreted the direct taxing clause extremely narrowly, allowing unapportioned taxes on the ownership of personal property, on inheritances, and on the issuance of bank notes, and suggesting that only taxes on real property and possibly general lists of personal property would be subject to apportionment.

\section{(3) The Direct Taxing Clause Under Pollock.}

Congress enacted the first non-war income tax in $1894 .^{168}$ Professor Bruce Ackerman claims that the 1894 income tax, which was modeled after the civil war income taxes that had been upheld in Soule and Springer, was imposed in the midst of a class war catalyzed by the financial panic of $1893 .{ }^{169}$ The string of governmental victories came to a screeching halt in the famous 1895 cases of Pollock v. Farmers' Loan \& Trust $^{170}$ in which the Court ultimately struck down the entire 1894 Act. Charles Pollock, a shareholder in Farmers Loan and Trust Company, sued the company to prevent it from paying taxes imposed under the 1894 Act on the income generated by the real and personal property that the corporation owned. ${ }^{171} \mathrm{Mr}$. Pollock claimed that Congress could not constitutionally tax the corporation's income from real and personal property

161102 U.S. $586(1880)$.

${ }^{162} I d$. at 596-97.

${ }^{163}$ Alexander Hamilton stated in his papers "direct taxes be held to be only "capitation or poll taxes, and taxes on lands and buildings, and general assessments, whether on the whole property of individuals or on their whole real or personal estate. All else must, of necessity, be considered as indirect taxes." Id. at 598.

${ }^{164} I d$.

${ }^{165} \mathrm{Id}$. at 599 .

${ }^{166} I d$. at 601-602.

${ }^{167} \mathrm{Id}$. at 602 .

${ }^{168}$ Tariff Act of 1894, ch. 349 at 27, 28 Stat. 509, 553 (1894) (declared unconstitutional in Pollock II, infra note 170 , in 1895). It is also worth noting that while business expenses were made deductible from income, there was no exclusion in the act for personal injury awards.

${ }^{169}$ See Ackerman, supra note 116, at 28.

170 157 U.S. 429 (1895) (Pollock I); 158 U.S. 601 (1895) (Pollock II).

${ }^{171}$ See prior history, cited in 157 U.S. 429 (1895). 
without apportionment, ${ }^{172}$ and could not constitutionally tax interest earned on the corporation's municipal bonds under implied federalism principles. ${ }^{173}$ Since Congress purported to tax income from real and personal property in the 1894 Act, Mr. Pollock sought a declaration that the 1894 Act was unconstitutional, and an injunction preventing Farmers Loan \& Trust from paying any of the income taxes. ${ }^{174}$

Chief Justice Fuller began his majority opinion in the first Pollock case by stating "in the matter of taxation, the Constitution recognizes the two great classes of direct and indirect taxes, and lays down two rules by which their imposition must be governed, namely: The rule of apportionment as to direct taxes, and the rule of uniformity as to duties, imposts and excises." 175 Chief Justice Fuller stated, essentially, that direct taxes in common parlance are those that cannot be avoided by conduct - taxes on mere ownership as opposed to taxes imposed on activities. ${ }^{176}$ However, Justice Fuller recognized that the Constitution might apply a different definition. He therefore proceeded to review the ambiguous constitutional debates, concluding initially that the drafters understood direct taxes to include taxes on real and personal property and the incomes therefrom. ${ }^{177}$

Justice Fuller then reviewed the Court's prior cases. He distinguished Hylton, Soule and Vesie as taxes on duties or excises (on the use of carriages, the operation of an insurance company, and the circulation of bank notes, respectively). ${ }^{178}$ Justice Chase distinguished Scholey as an excise on the transfer of property at death. ${ }^{179}$ Finally, the Court struggled to distinguish the income tax in Springer by going back to the original record to find "that the income ... was in part professional as attorney-at-law and the rest interest on United States bonds," not from property. ${ }^{180}$

After reviewing the cases, the Court equivocated on whether a tax on income from personal property would constitute a direct tax, concluding only "that the law in question, so far as it levies a tax on the rents or income of real estate, is in violation of the Constitution, and is invalid." 181 The Court, unanimously, ${ }^{182}$ agreed with Mr. Pollock that the tax on municipal bond interest was unconstitutional under federalism principles. ${ }^{183}$

\footnotetext{
${ }^{172} \mathrm{Mr}$. Pollock also argued that the tax on income from property was not uniform because certain entities were excepted from the tax. Pollock I, 157 U.S. at 555.

${ }^{173} I d$.

${ }^{174} \mathrm{Id}$.

${ }^{175}$ Pollock I, 157 U.S. at 557. Justice Fuller noted that some questioned whether there was a third category of indirect taxes that did not constitute a "duty, impost or excise," but noted that "such a tax for more than one hundred years of national existence has as yet remained undiscovered" Id.

${ }^{176} I d$. at 680 ("Ordinarily all taxes paid primarily by persons who can shift the burden upon some one else, or who are under no legal compulsion to pay them, are considered indirect taxes; but a tax upon property holders in respect of their estates, whether real or personal, or of the income yielded by such estates, and the payment of which cannot be avoided, are direct taxes.").

${ }^{177}$ Id. at 574 .

${ }^{178} \mathrm{Id}$. at $576-77$.

${ }^{179} \mathrm{Id}$. at 577.

${ }^{180} \mathrm{Id}$. at $578-79$.

${ }^{181} \mathrm{Id}$. at 583 .

${ }^{182} \mathrm{Id}$. at 717. See also Id. at 653-54 (Harlan, J., dissenting).

${ }^{183} \mathrm{Id}$. at 586 ("it is obvious that taxation on the interest [from municipal bonds] would operate on the power to borrow before it is exercised, and would have a sensible influence on the contract, and that the tax in question is a tax on the power of the States and their instrumentalities to borrow money, and consequently repugnant to the Constitution.").
} 
Justice Field wrote a lengthy concurring opinion arguing that the entire tax act should be declared unconstitutional. Justice Field contended that taxes on income from non-property sources such as wages - which even he conceded constituted "duties, imposts and excises" and thus required no apportionment - were not uniform because of the modest progressive structure of the Act - the first $\$ 4,000$ of income was exempted. Justice Field saw the exemption as an attack on wealth, and as an invitation to class warfare. ${ }^{184}$ To Justice Field, uniformity meant more than geographic uniformity, it required all taxpayers to pay ratably. ${ }^{185}$ No other justice joined Justice Field in these views. Justice White, joined by Justice Harlan, wrote a lengthy dissent arguing on the basis of precedent that direct taxes should be limited to taxes on real property itself, and should not cover taxes on income from real property. ${ }^{186}$

In Pollock 2, ${ }^{187}$ a five-to-four divided Supreme Court revisited the case and expanded its ruling. The Court first held that a tax on income from personal property was also a direct tax that had to be apportioned. The Court's decision was supported primarily by statements made by Alexander Hamilton in his papers regarding the Hylton case, which had been published after his death, ${ }^{188}$ and on decisions of English courts. ${ }^{189}$ The Court stated that the tax in income from personal property was direct because the taxpayer had no means of escape. ${ }^{190}$ However, this theory is highly questionable. Taxpayers do not need to rent or sell their property - income generally results from people engaging in transactions with their property, which is the usual province of an excise. The Court treated the source of the income (from property) as controlling, rather than considering whether the income arose out of a transaction.

After holding that the broad based tax on all income from real and personal property was direct and had to be apportioned, the Court considered whether the tax act as a whole should be declared unconstitutional, or whether the unconstitutional portions (the tax on income from property and municipal bonds) should be severed from the constitutional portions (which the Court characterized as a tax on incomes from "business, privileges, or employments.") ${ }^{191}$ The Court noted that most of the expected

${ }^{184}$ Id. at 597 (Field, J., concurring).

${ }^{185} \mathrm{Id}$. at 607-608.

${ }^{186} \mathrm{Id}$. beginning at 829 .

${ }^{187} 158$ U.S. 601 (1895).

${ }^{188} \mathrm{Id}$. at 625 (quoting Alexander Hamilton as follows: "The following are presumed to be the only direct taxes. Capitation or poll taxes. Taxes on lands and buildings. General assessments, whether on the whole property of individuals, or on their whole real or personal estate; all else must of necessity be considered as indirect taxes."). The Court adopted Hamilton's statement as a definition of direct taxes. Id. ("He gives, however, it appears to us, a definition which covers the question before us. A tax upon one's whole income is a tax upon the annual receipts from his whole property, and as such falls within the same class as a tax upon that property, and is a direct tax, in the meaning of the Constitution.") It is important to note that Hamilton did not discuss a tax on income - his statement covered only a tax on a person's entire property or estate. The Court on its own extended the analysis to income from property.

${ }^{189} I d$. at 630-632.

${ }^{190} I d$. at 627-28 ("can it be properly held that the Constitution . . . authorizes a general un-apportioned tax on the products of the farm and the rents of real estate, although imposed merely because of ownership and with no possible means of escape from payment, as belonging to a totally different class from that which includes the property from whence the income proceeds?").

${ }^{191} I d$. at 635 ("We have considered the act only in respect of the tax on income derived from real estate, and from invested personal property, and have not commented on so much of it as bears on gains or profits from business, privileges, or employments, in view of the instances in which taxation on business, 
revenue from the 1894 Act was to come from the unconstitutional tax on income from real and personal property, and only a small portion was to come from the constitutional tax on other income, including wages and professional earnings. ${ }^{192}$ The Court held that Congress would not have intended for the constitutional portions to survive alone, and therefore it struck down the entire Act. ${ }^{193}$

Four justices joined a famous ${ }^{194}$ dissent written by Justice Harlan. ${ }^{195}$ The dissenters distinguished between a tax on land and a tax on income from land, the former being direct and reasonably subject to apportionment, while the latter should be treated as an excise. ${ }^{196}$ The dissenters also argued that all taxes on personal property or income therefrom should be treated as indirect, ${ }^{197}$ and that the decision as a whole was a threat to the security of the country by effectively limiting the subjects of taxation. ${ }^{198}$

It is important to note that the Pollock majority recognized Congress's power to tax all types of income without apportionment other than taxes on real and personal property or the income therefrom, including income from "business, privileges, or employments." There was no question raised by any of the judges in Pollock over Congress's power to tax wages and other revenues generated from what we today call human capital. Indeed, Pollock implicitly recognized Congress's ability to tax without apportionment all sources of income not from real or personal property (or municipal bonds).

privileges, or employments has assumed the guise of an excise tax and been sustained as such. Being of opinion that so much of the sections of this law as lays a tax on income from real and personal property is invalid, we are brought to the question of the effect of that conclusion upon these sections as a whole.").

${ }^{192} I d$. at 637 ("[B]y far the largest part of the anticipated revenue would be eliminated, and this would leave the burden of the tax to be borne by professions, trades, employments, or vocations; and in that way what was intended as a tax on capital would remain in substance a tax on occupations and labor. We cannot believe that such was the intention of Congress.").

${ }^{193} I d$. ("[A]ll those sections, constituting one entire scheme of taxation, are necessarily invalid.").

${ }^{194}$ Professor Bruce Ackerman claims that Justice Harlan's dissent in Pollock was far more famous at the turn of the century than was his dissent in Plessy v. Ferguson, 163 U.S. 537 (1896), which has become a law school textbook staple. See Ackerman, supra note 116, at 29.

${ }^{195}$ Justices White, Brown and Jackson joined Harlan in his dissent.

${ }^{196} I d$. at 665 (Harlan, J., dissenting) ("Assuming it to be the settled construction of the Constitution that the general government cannot tax lands, eo nomine, except by apportioning the tax among the States according to their respective numbers, does it follow that a tax on incomes derived from rents is a direct tax on the real estate from which such rents arise? In my judgment a tax on income derived from real property ought not to be, and until now has never been, regarded by any court as a direct tax on such property within the meaning of the Constitution.").

${ }^{197} I d$. at 670 ("When direct taxes are restricted to capitation taxes and taxes on land, taxation, in either form, is limited to subjects always found wherever population is found, and which cannot be consumed or destroyed. They are subjects which can always be seen and inspected by the assessor, and have immediate connection with the country and its soil throughout its entire limits. Not so with personal property.").

${ }^{198}$ See Id. at 671-72 ("No such apportionment can possibly be made without doing gross injustice to the many for the benefit of the favored few in particular States. Any attempt upon the part of Congress to apportion among the States ... would tend to arouse such indignation among the freemen of America that it would never be repeated. When, therefore, this court adjudges, as it does now adjudge, that Congress cannot impose a duty or tax upon personal property, or upon income arising either from rents of real estate or from personal property, including invested personal property, bonds, stocks, and investments of all kinds, except by apportioning the sum to be so raised among the States according to population, it practically decides that, without an amendment of the Constitution ... such property and incomes can never be made to contribute to the support of the national government."). 
The negative political reaction to the split decision in Pollock ${ }^{199}$ led quickly to retreat. Four years after Pollock, in Knowlton v. Moore, ${ }^{200}$ the justices unanimously ${ }^{201}$ agreed that the War Revenue Act of $1898,{ }^{202}$ which imposed an unapportioned tax with progressive rates on legatees who receive property from a deceased person's estate, was constitutional. In an opinion by Justice White, one of the Pollock dissenters, the Court first noted that the tax was not on property itself, but on the transfer of property from the decedent to the legatees. The Court stated that inheritance taxes:

[A]re included officially under the general denomination of indirect taxes ... [because they] are considered as levied on the "occasion of a particular isolated act." This view of the inheritance and legacy tax conforms to the official definition of indirect taxes, among which inheritance and legacy taxes are classed, which prevails in France at the present day. The definition is as follows: "Direct taxes bear immediately upon persons, upon the possession and enjoyments of rights; indirect taxes are levied upon the happening of an event or an exchange. 203

This theory is very different from the theory underlying Pollock, which focused on whether the source of the item subject to tax was property, rather than whether the item subject to tax was generated from an "event or exchange."

The Court in Knowlton also noted that a similar succession tax had been upheld in Scholey. ${ }^{204}$ However, the Court had to address the tangle of authority created by the interplay of Pollock and Scholey. The tangle was caused because Scholey, in upholding the succession tax, had analogized it to an income tax - both of which according to Scholey were indirect. ${ }^{205}$ The taxpayers in Knowlton argued that Scholey must have been over-ruled by Pollock's holding that taxes on income from property were direct and had to be apportioned. ${ }^{206}$ The majority in Knowlton disagreed with the taxpayer's argument, holding that the precise holding in Scholey regarding succession taxes had in fact been "reaffirmed" by the Pollock Court when it distinguished Scholey as dealing only with the succession taxes that were before it. In essence, Pollock only rejected the dicta in

\footnotetext{
${ }^{199}$ See Ackerman, supra note 116, at 31.

${ }^{200} 178$ U.S. 41 (1900).

${ }^{201}$ Three judges dissented in Knowlton. Justice Brewer dissented from the Court's holding on the meaning of the uniformity requirement, contending that a progressive tax would not be uniform. $I d$. at 110 . Justices Harlan and McKenna dissented only to the majority's interpretation of that the tax rate be determined by the amount of each distributee's share rather than to the whole estate. Justices Harlan \& McKenna specifically agreed with Constitutional views of the majority. $I d$.

20220 Stat. 448 (1898).

${ }^{203}$ Knowlton, 178 U.S. at 47.

${ }^{204} \mathrm{Id}$. at 52; see also discussion of Scholey, supra, beginning at note 159 .

${ }^{205}$ See supra at note 81.

${ }^{206}$ Knowlton, 178 U.S. at 80.
} 
Scholey regarding income taxes, and reaffirmed the holding regarding succession taxes. ${ }^{207}$

The Court in Knowlton next rejected the taxpayer's argument that since the inheritance tax could not be shifted to another taxpayer it was a direct tax requiring apportionment. Knowlton held that the Court in Pollock did not ground its decision on the economic theory of shiftability. ${ }^{208}$ Rather, the Knowlton Court said that Pollock was grounded on the theory that the tax on income from property was a tax on the property itself. On the other hand, the inheritance tax in Knowlton was a duty or excise on the transfer at death, not a tax on income, and therefore could be analyzed differently.

It is difficult to reconcile the theory used by the Court in Knowlton with Pollock's source rule, since the source of the inheritance tax in Knowlton, like the source of the income tax in Pollock, was property. Although the Knowlton Court professed to distinguish Pollock, its focus on the activity of transfer rather than the source of the item being taxed marked a substantial theoretical departure. The theory used in Knowlton, which focused on whether there was any activity triggering tax rather than on whether the source of the item taxed was property, would have changed the result in Pollock. After all, the corporate taxpayer in Pollock was engaged in activities (leasing property and managing investments) that gave rise to the income that was subject to tax.

After concluding that the inheritance tax was an indirect duty or excise triggered by the transfer of property at death, the Knowlton Court considered the taxpayer's argument that the tax was not uniform because of the $\$ 10,000$ exemption and progressive rate structure employed by the statute. ${ }^{209}$ The Court began by recognizing that many states had rules requiring equality and uniformity in taxation that would have been violated by the statute. ${ }^{210}$ The Court focused closely, however, on the constitutional language requiring uniformity "throughout the United States."

Considering the text, it is apparent that if the word "uniform" means "equal and uniform" in the sense now asserted by the opponents of the tax, the words "throughout the United States" are deprived of all real significance, and sustaining the contention

\footnotetext{
${ }^{207}$ Id. at 81 .

${ }^{208} I d$. at 82 ("The fallacy is in the premise. It is true that in the income tax cases the theory of certain economists by which direct and indirect taxes are classified with reference to the ability to shift the same was adverted to. But this disputable theory was not the basis of the conclusion of the court. The constitutional meaning of the word direct was the matter decided. Considering that the constitutional rule of apportionment had its origin in the purpose to prevent taxes on persons solely because of their general ownership of property from being levied by any other rule than that of apportionment, two things were decided by the court: First, that no sound distinction existed between a tax levied on a person solely because of his general ownership of real property, and the same tax imposed solely because of his general ownership of personal property. Secondly, that the tax on the income derived from such property, real or personal, was the legal equivalent of a direct tax on the property from which said income was derived, and hence must be apportioned. These conclusions, however, lend no support to the contention that it was decided that duties, imposts and excises which are not the essential equivalent of a tax on property generally, real or personal, solely because of its ownership, must be converted into direct taxes, because it is conceived that it would be demonstrated by a close analysis that they could not be shifted from the person upon whom they first fall.").

${ }^{209} \mathrm{Id}$. at 83-84.

${ }^{210} I d$. at 84 .
} 
must hence lead to a disregard of the elementary canon of construction which requires that effect be given to each word of the Constitution. ${ }^{211}$

The Court therefore adopted a geographic definition of uniformity, suggesting that only a duty, impost or excise that discriminated on its face depending on the geographic location of the taxpayer would lack uniformity.

In Thomas v. United States, ${ }^{212}$ the Court again retreated from Pollock by holding that a tax on the transfer of stock certificates was indirect. Mr. Thomas, a stockbroker, who had been criminally indicted and convicted for failing to pay the tax, argued that the tax was an unapportioned direct tax and therefore invalid. In a unanimous opinion by Justice Fuller, the author of Pollock, upholding the conviction, the Court said:

There is no occasion to attempt to confine the words duties, imposts and excises to the limits of precise definition. We think that they were used comprehensively to cover customs and excise duties imposed on importation, consumption, manufacture and sale of certain commodities, privileges, particular business transactions, vocations, occupations and the like. Taxes of this sort have been repeatedly sustained by this court, and distinguished from direct taxes under the Constitution. ${ }^{213}$

The tax in Thomas was imposed on an item of personal property, as in Pollock 2, yet the Court looked not to the source or base of the tax - personal property in the form of stock, but to the acts giving rise to the tax - the transfer of personal property. In attempting to explain its ruling in Thomas, the Court fell back on the transactional concept it had expressed in Knowlton, and also mentioned a new second theory - corporate privilege - that would soon be expanded:

The sale of stocks is a particular business transaction in the exercise of the privilege afforded by the laws in respect to corporations of disposing of property in the form of certificates. The stamp duty is contingent on the happening of the event of sale, and the element of absolute and unavoidable demand is lacking. As such it falls, as stamp taxes ordinarily do, within the second class of the forms of taxation. $^{214}$

As with Knowlton, the theory used by the Court in Thomas is difficult to reconcile with the theory used by the Court in Pollock. Why, for example, would a tax on the income generated by a sale of stock be direct under Pollock, while a tax on the gross proceeds from the sale of stock would be indirect under Thomas? The only way to

${ }^{211} I d$. at 87 .

212192 U.S. 363 (1904).

${ }^{213} I d$. at 370 .

${ }^{214}$ Id. at 371 . 
reconcile these cases is to suggest that a tax on income from property is more direct than a tax on the property itself. The absurdity of the proposition is manifest, and shows that the standards used by the Court were changing.

In the same year as Thomas, the Court in Spreckels Sugar Refining Co. v. $M c$ Clain $^{215}$ upheld a tax on the gross proceeds from the sale of sugar. The Court, in a unanimous decision by Justice Harlan, a Pollock dissenter, held that the tax was an excise on the business of refining sugar, and not a direct tax on property ownership. ${ }^{216}$ The Court emphasized that Congress in the statute called the tax a "special excise." Because Congress labeled it an excise, said the Court, "it must be assumed, for what it is worth, that Congress had no purpose to exceed its powers under the Constitution, but only to exercise the authority granted to it of laying and collecting excises." 217 The Spreckels Court disposed of Pollock, which it called The Income Tax Cases, in two sentences, saying that the Court there said that it was not commenting on "'gains or profits from business, privileges or employments, in view of the instances in which taxation on business, privileges or employments has assumed the guise of an excise tax and been sustained as such.'"218 But of course the question in Pollock was whether income from an investment business could constitutionally be taxed. Once again, the Spreckels Court's underlying theory - focusing on the identity or activities of the taxpayer rather than the source of the item taxed - was a marked departure from the Court's theory in Pollock, and would have changed the result there.

Taking the hint from Spreckels and Thomas that a tax on the privilege of doing business in corporate form would be a valid excise, Congress passed a new corporate income tax in 1909. ${ }^{219}$ The 1909 law imposed "a special excise tax with respect to the carrying on or doing business by such corporation . . . equivalent to one per centum upon the entire net income over and above five thousand dollars received by it from all sources during the year." Only dividends received by one corporation from another who had already paid the tax were excluded. ${ }^{220}$

The 1909 Corporate Income Tax was upheld by the Court as a valid excise in Flint v. Stone Tracy Co., ${ }^{221}$ a unanimous opinion written by Justice Day. As in the other post-Pollock cases, the Court again emphasized Congress's stated purpose to impose an excise rather than a direct tax. ${ }^{222}$ In distinguishing Pollock, the Court stated:

\footnotetext{
215192 U.S. 397 (1904).

${ }^{216} \mathrm{Id}$. at 411 ("Clearly the tax is not imposed upon gross annual receipts as property, but only in respect of the carrying on or doing the business of refining sugar. It cannot be otherwise regarded because of the fact that the amount of the tax is measured by the amount of the gross annual receipts. The tax is defined in the act as "a special excise tax," and, therefore, it must be assumed, for what it is worth, that Congress had no purpose to exceed its powers under the Constitution, but only to exercise the authority granted to it of laying and collecting excises.").

${ }^{217} I d$.

${ }^{218}$ Id. at 413, quoting from Pollock II, 158 U.S. at 635.

21936 Stat. 11 (1909).

${ }^{220} \mathrm{Id}$. at 144 .

221220 U.S. 107 (1911).

${ }^{222} \mathrm{Id}$. at 145 ('While the mere declaration contained in a statute that it shall be regarded as a tax of a particular character does not make it such if it is apparent that it cannot be so designated consistently with the meaning and effect of the act, nevertheless the declaration of the lawmaking power is entitled to much weight, and in this statute the intention is expressly declared to impose a special excise tax with respect to the carrying on or doing business by such corporation ... It is therefore apparent, giving all the words of
} 
In the present case the tax is not payable unless there be a carrying on or doing of business in the designated capacity, and this is made the occasion for the tax, measured by the standard prescribed. The difference between the acts is not merely nominal, but rests upon substantial differences between the mere ownership of property and the actual doing of business in a certain way. ${ }^{223}$

Was the income earned by the corporation in Pollock not the result of "actual doing of business in a certain way?" Indeed, the Court in Flint considered the objections of real estate companies (including one whose only asset was a hotel), and ruled that such entities could be taxed because they were engaged in business activities:

We think it is clear that corporations organized for the purpose of doing business, and actually engaged in such activities as leasing property, collecting rents, managing office buildings, making investments of profits, or leasing ore lands and collecting royalties, managing wharves, dividing profits, and in some cases investing the surplus, are engaged in business within the meaning of this statute, and in the capacity necessary to make such organizations subject to the law. ${ }^{224}$

One could surmise that the only real basis for the Court in Flint to distinguish Pollock was Congress's statement in the 1909 statute calling the tax an "excise." Surely Congress's constitutional power to tax could not depend merely on Congress making a self-serving statement in the statute. Despite the sophistry, by the time of Flint the standard had changed from focusing on the source of the income to focusing on whether or not the income came from an activity.

In Zonne v. Minneapolis Syndicate, ${ }^{225}$ a case argued at the same time as Flint but decided later, ${ }^{226}$ the Court held that a corporation, which had leased all of its property to a single lessee for 130 years, and had amended its charger to permit it to own only the property subject to the lease, was not "doing business" and therefore was not subject to the Corporate Tax Law of 1909. The Court's decision in Zonne was based on the language of the statute, not on any constitutional limitation on Congress's power to tax. Yet, the specter of Pollock hung over the decision, for without sufficient business activity the new constitutional theory, under which taxes on income from business activities constitute "duties or excises," would not logically apply. ${ }^{227}$

the statute effect, that the tax is imposed not upon the franchises of the corporation irrespective of their use in business, nor upon the property of the corporation, but upon the doing of corporate or insurance business and with respect to the carrying on thereof.").

${ }^{223} I d$. at 150 .

${ }^{224} I d$. at 171.

${ }^{225} 220$ U.S. 187 (1911).

${ }^{226}$ See McCoach v. Minehill \& S. H. R. Co., 228 U.S. 295, 310 (1913).

${ }^{227}$ The Court in McCouch v. Minehill, 228 U.S. 295 (1913), followed Zonne in holding that a railroad that had leased its property, and maintained a staff to invest the rents, was not engaged in business within the 
Flint was followed in Stratton's Independence, Ltd. v. Howbert, ${ }^{228}$ where the court distinguished between a broad income tax as in Pollock, and an excise tax on a corporation engaged in business that is measured by income. ${ }^{229}$ The Court in Stratton's made some comments about the distinction between a tax on business activity and a tax on property that would later be used by the Court to define the meaning of "income" under the 16th Amendment: ${ }^{230}$

The sale outright of a mining property might be fairly described as a mere conversion of the capital from land into money. But when a company is digging pits, sinking shafts, tunneling, drifting, stoping, drilling, blasting, and hoisting ores, it is employing capital and labor in transmuting a part of the realty into personalty, and putting it into marketable form. The very process of mining is, in a sense, equivalent in its results to a manufacturing process. And, however the operation shall be described, the transaction in indubitably "business" within the fair meaning of the act of 1909; and the gains derived from it are properly and strictly the income from that business; for "income" may be defined as the gain derived from capital, from labor, or from both combined, and here we have combined operations of capital and labor. ${ }^{231}$

Beginning in 1909 there was strong support in Congress for enacting a new broad-based income tax with which to challenge Pollock head-on. However, President Taft sought to avoid the dispute by proposing a compromise - a constitutional amendment that would permit a broad based income tax without apportionment. ${ }^{232}$ The compromise led to the enactment of the 16th Amendment in 1913.

The courts never fully developed the distinction between direct and indirect taxation because Congress passed and the States adopted the 16th Amendment to the United States Constitution in 1913. However, it is important to recognize that the Court had retreated from the theory it had used in Pollock - that Congress could not, without apportionment, tax income from property because it would constitute a direct tax on the property itself. Instead, the post-Pollock cases focused on the conduct of the taxpayer (and to some extent on the identity of the taxpayer) ${ }^{233}$ rather than the source of the revenue, and specifically upheld the 1909 corporate income tax in situations that would not have survived under the theory utilized in Pollock.

meaning of the Corporate Tax Law of 1909. Three dissenters argued that the continuing investment activities were enough to constitute the carrying on of a business.

${ }^{228} 231$ U.S. 399 (1913).

${ }^{229} \mathrm{Id}$. at 416-17 ("Congress in exercising the right to tax a legitimate subject of taxation as a franchise or privilege, was not debarred by the Constitution from measuring the taxation by the total income, although derived in part from property which, considered by itself, was not taxable.").

${ }^{230}$ See discussion of Eisner v. Mc Comber, infra beginning at note 354.

${ }^{231} I d$. at 414-15 (emphasis added).

${ }^{232}$ The history of the negotiations leading to a constitutional amendment are set forth in Ackerman, Taxation and the Constitution, supra note 116, at 34-39.

${ }^{233}$ The Court's identity theory suggested that Congress would have the power to tax a corporation simply because it was permitted to exist and conduct business, that its corporate existence might be enough to categorize a tax imposed on a corporation engaged in business as an excise. 
Moreover, all of the early cases, including Pollock, recognized that Congress always possessed the power to tax income from what we call today human capital, such as wages, without apportionment. ${ }^{234}$ Pollock only questioned the Court's ability to tax income from real or personal property without apportionment. What remained of Pollock at the time of the adoption of the 16th Amendment was a prohibition against imposing unapportioned taxes on the mere ownership of real or personal property, or on income arising solely out of that mere ownership, absent transactional activity triggering the tax.

It is also important to note that the period following Pollock and before the adoption of the 16th Amendment saw the turnover of nearly the entire Court. Of the nine justices serving when Pollock was decided, ${ }^{235}$ only Justice White, a dissenter, ${ }^{236}$ was still on the Court in $1913 .^{237}$ And it was an elderly Justice White, writing for a unanimous Supreme Court, who would later formally reject Pollock's source rule. ${ }^{238}$

\section{(5) The 16th Amendment and the Judicial Rejection of Pollock's Source Rule}

The 16th Amendment eliminated any remaining constitutional requirement that taxes on income be apportioned. It provided:

The Congress shall have power to lay and collect taxes on incomes, from whatever source derived, without apportionment among the several States, and without regard to any census or enumeration. ${ }^{239}$

The Supreme Court would say many times that the 16th Amendment did not grant to Congress any new power of taxation. ${ }^{240}$ Congress had the power under the original

\footnotetext{
${ }^{234} \mathrm{Id}$. at 415 ("As to the alleged inequality of operation between mining corporations and others, it is of course true that the revenues derived from the working of mines result to some extent in the exhaustion of the capital. But the same is true of the earnings of the human brain and hand when unaided by capital, yet such earnings are commonly dealt with in legislation as income.").

${ }^{235}$ The justices on the Court in 1898 were Justices Fuller, Harlan, Field, Gray, Brewer, Brown, Shiras, White and Peckham. See Members of THE Supreme Court of THE United StAtes, available at http://www.infoplease.com/ipa/A0101281.html (2006)

236 See supra note 195.

${ }^{237}$ The justices in 1913 were McKenna, Holmes, Day, Lurton, Hughes, Van Devanter, Lamar, Pitney and White. See Members of the Supreme Court of the United StateS, supra note 235.

${ }^{238}$ See discussion infra beginning at note 247.

${ }^{239}$ U.S. CONST. art XVI (1913).

${ }^{240}$ See e.g. Eisner v. Macomber, 252 U.S. 189, 206 (1920) ("As repeatedly held, this [the 16th Amendment] did not extend the taxing power to new subjects, but merely removed the necessity which otherwise might exist for an apportionment among the States of taxes laid on income."); Stanton v. Baltic Mining Co., 240 U.S. 103, 112-13 (1916) ("the provisions of the Sixteenth Amendment conferred no new power of taxation but simply prohibited the previous complete and plenary power of income taxation possessed by Congress from the beginning from being taken out of the category of indirect taxation to which it inherently belonged and being placed in the category of direct taxation subject to apportionment by a consideration of the sources from which the income was derived, that is by testing the tax not by what it was -- a tax on income, but by a mistaken theory deduced from the origin or source of the income taxed."); Brushaber v. Union P. R. Co., 240 U.S. 1, 11-18 (1918) ('It is clear on the face of this text [of the 16th Amendment] that it does not purport to confer power to levy income taxes in a generic sense - an
} 
Constitution to impose all forms of taxes, other than taxes on exports, including any type of property or income tax. The 16th Amendment simply eliminated the requirement from Pollock that taxes on income from real and personal property be apportioned - a requirement that by 1913 only applied if the income from the real or personal property had not resulted from an activity or transaction. The 16th Amendment thus repudiated the Supreme Court's theory in Pollock by eliminating the one potential impediment to the imposition of broad-based income taxes - the requirement of apportionment applicable to taxes on income from the mere ownership of real or personal property.

The 16th Amendment did not, however, eliminate the apportionment requirement entirely. The apportionment requirement remains for direct taxes that are not income taxes, as the 16th Amendment applies by its terms only to "taxes on incomes."241 Thus, for example, under the consistent rulings of the Supreme Court, Congress would still not be able to impose a traditional ad valorem real property tax without apportionment. ${ }^{242}$ In addition, the constitutional amendment made no change in the geographical uniformity requirement for duties, imposts and excises. ${ }^{243}$

Following adoption of the 16th Amendment in 1913, Congress quickly imposed a broad based income tax. ${ }^{244}$ In Brushaber $v$. Union Pacific, ${ }^{245}$ a case procedurally identical to Pollock, a stockholder sought to enjoin a corporation from paying income taxes imposed under the Tariff Act of 1913. The Supreme Court upheld the validity of the income tax without apportionment under the 16th Amendment, and rejected the

authority already possessed and never questioned - or to limit and distinguish between one kind of income taxes and another, but that the whole purpose of the Amendment was to relieve all income taxes when imposed from apportionment from a consideration of the source whence the income was derived.").

Congress's plenary power under the Constitution to impose all forms of taxation other than taxes on exports was settled long before the enactment of the 16th Amendment. See e.g. Pollock v. Farmers' Loan \& Trust Co. (Pollock II), 158 U.S. 601, 618 (1895) ("The power to lay direct taxes apportioned among the several States in proportion to their representation in the popular branch of Congress, a representation based on population as ascertained by the census, was plenary and absolute; but to lay direct taxes without apportionment was forbidden. The power to lay duties, imposts, and excises was subject to the qualification that the imposition must be uniform throughout the United States."); Hylton v. United States, 3 U.S. 171, 176 (1796) (Patterson, J.) ("It was, however, obviously the intention of the framers of the Constitution, that Congress should possess full power over every species of taxable property, except exports. The term taxes, is generical, and was made use of to vest in Congress plenary authority in all cases of taxation.")

${ }^{241}$ U.S. CONST. art XVI (1913) ("The Congress shall have the power to lay and collect taxes on incomes, from whatever source derived, without apportionment among the several States, and without regard to any census or enumeration.").

${ }^{242}$ Every Court from Hylton to Pollock recognized that, at a minimum, a real property tax would have to be apportioned. Since such a tax would be on value and not on income, the 16th Amendment should not have changed the Constitutional mandate. I have heard some academics argue that a property tax should be permissible without apportionment if the tax did not exceed the rate of income from property generally, or the rate of tax earned on the property. Aside from the technical problems inherent in justifying a property tax as an income tax (some property does not earn income, for example), the Court's decisions in Spreckels, Thomas and Flint put substantial weight on the form of the tax, casting significant doubt on the ability of courts to recharacterize an ad valorem property tax as an income tax.

${ }^{243}$ The amendment leaves open the question of whether income taxes have to be geographically uniform. To the extent Pollock remains good law, taxes on income from property could be imposed in a non-uniform manner because they do not constitute "duties, imposts and excises."

${ }^{244}$ Tariff Act of October 3, 1913, Pub. L. No. 63-16, § II, Ch. 16, 38 Stat. 166 (1913).

245240 US 1 (1916) 
argument that the 16th Amendment conflicted with a limited taxing power contained in the Constitution. The Court held that the 16th Amendment eliminated the apportionment requirement for direct income taxes - it did not create a new taxing power, and thus did not create a conflict. ${ }^{246}$

In Stanton v. Baltic Mining Co. ${ }^{247}$ Justice White finally took his revenge against the Pollock majority. A shareholder in a mining company claimed that the 1913 Act effectively imposed a tax not on the mining company's "income," but on its property without apportionment, because the Act did not allow adequate depletion allowances to be deducted from its gross receipts. ${ }^{248}$ Justice White's opinion for a unanimous Court upheld the tax both because it was within the 16th Amendment, and, even if it had not been within the Amendment, because it was as a valid excise on the operation of the mine in accordance with the Court's pre-16th Amendment decision in Stratton's. ${ }^{249}$ Baltic Mining shows that a court considering the constitutionality of a tax must look not only to the 16th Amendment, but also to any other taxing powers given to Congress in Article I of the Constitution. A purported tax on income which is outside of the 16th Amendment is not per-say unconstitutional, since it may be within Congress's general taxing power. And, according to the Court in Baltic Mining, that general taxing power allows Congress to tax as income, without apportionment, items that may not constitute "income" within the meaning of the 16th Amendment. For example, a tax not on "income" within the meaning of the 16th Amendment could still be upheld without apportionment if it constituted a "duty or excise" attributable to the taxpayer's conduct. Indeed, this was the basis upon which the Court had repeatedly upheld the 1909 Corporate Income Tax Act.

The Court in Baltic Mining also made a direct assault on the "source" theory utilized in Pollock, calling it a "mistaken theory:"

[T] he provisions of the Sixteenth Amendment conferred no new power of taxation but simply prohibited the previous complete and plenary power of income taxation possessed by Congress from the beginning from being taken out of the category of indirect taxation to which it inherently belonged and being placed in the category of direct taxation subject to apportionment by a consideration of the sources from which the income was derived, that is by testing the tax not by what it was - a tax on income, but by a mistaken theory deduced from the origin or source of the income taxed. ${ }^{250}$

Pollock was not over-ruled in Baltic Mining, but only because Pollock's "erroneous" source theory had been mooted by the adoption of the 16th Amendment.

\footnotetext{
${ }^{246}$ Id. at $112-13$; See also supra note 240.

247240 U.S. 103 (1916).

${ }^{248}$ The statute limited depletion allowances to $5 \%$ of gross receipts. $I d$. at 110 .

${ }^{249} \mathrm{Id}$. at 114 ("[I]ndependently of the effect of the operation of the Sixteenth Amendment it was settled in Stratton's Independence v. Howbert, 231 U.S. 399, that such a tax is not a tax upon property as such because of its ownership, but a true excise levied on the results of the business of carrying on mining operations.").

${ }^{250} I d$. at 112 (emphasis added).
} 
The court of appeals in Murphy held that Ms. Murphy's emotional distress damages award was not "income" within the meaning of the 16th Amendment, and therefore Congress lacked the power to tax the award. ${ }^{251}$ The court of appeals erred in reaching this conclusion. As shown above, the correct constitutional question was whether Congress had the power under any provision of the Constitution to tax Ms. Murphy's damages award, not whether the award could be taxed under the 16th amendment. ${ }^{252}$

If, as the court of appeals held, Ms. Murphy's damages award was not "income" within the meaning of the 16th Amendment, ${ }^{253}$ then the court of appeals should have "search[ed] the Constitution to ascertain whether or not the power is conferred." 254 In searching the Constitution, the court of appeals should have discovered Article I of the Constitution, which authorized Congress to tax anything other than exports, but required direct taxes to be apportioned. ${ }^{255}$ Therefore, after holding that Ms. Murphy's damages award was not "income" within the meaning of the 16th Amendment, the court of appeals should have proceeded to determine whether the tax imposed on Ms. Murphy's damages award was a direct tax requiring apportionment (in which case Congress's attempt to tax Ms. Murphy's award without apportionment would be unconstitutional), or whether it was an indirect duty or excise which could be lawfully imposed without apportionment.

There are two alternative reasons for treating the taxation of Ms. Murphy's damages award as an indirect "duty or excise" requiring no apportionment, even if the award did not constitute "income" within the meaning of the 16th Amendment. As discussed below, the tax on Ms. Murphy's award was a valid duty or excise both because Ms. Murphy engaged in a transaction when she exchanged her emotional distress damages for cash, and because taxes on what we today call human capital were never considered by the courts direct taxes on property requiring apportionment.

\section{(a) Congress Could Tax Ms. Murphy's Exchange of Emotional Distress Damages for Cash.}

The first reason to treat the tax on Ms. Murphy's award as a "duty or excise" that could be taxed without apportionment is that Ms. Murphy engaged in a transaction when she sold her emotional and reputational damages for cash.

Congress's original Article I powers included the unfettered authority to tax duties and excises without apportionment. ${ }^{256}$ The Court specifically recognized, both prior to the adoption of the 16th Amendment and afterwards, that Congress had the power to tax the gross proceeds from the sale of property. For example, before Pollock questioned Congress's ability to tax income from real or personal property without

\footnotetext{
${ }^{251}$ Murphy, 160 F.3d at 92 ("Murphy's compensatory award ... was not ... within the meaning of the term 'incomes' as used in the Sixteenth Amendment.")

${ }^{252}$ See discussion supra beginning at note 105.

${ }^{253}$ Murphy, 460 F.3d at 92.

${ }^{254}$ See United States v. Harris, 106 U.S. 629, 636 (1883), discussed supra at note 105.

${ }^{255}$ See discussion supra beginning at note 110 .

${ }^{256}$ See supra beginning at note 110.
} 
apportionment, the Supreme Court had upheld taxes on the gross proceeds from the issuance of bank notes, ${ }^{257}$ and on the gross proceeds inherited at death. ${ }^{258}$ These authorities were reaffirmed in Pollock, and distinguished on the grounds that they were not taxes on income from property, but rather taxes on activites. Following Pollock, the Court made it clear that Congress had the power to tax transactions, without apportionment, because they constitute indirect duties or excises rather than direct taxes on the mere ownership of property. ${ }^{259}$ After Pollock, the Supreme Court reaffirmed Congress's power to tax the gross proceeds transferred at death, ${ }^{260}$ the transfer of stock certificates without respect to income, ${ }^{261}$ and most importantly the gross proceeds from the sale of sugar. ${ }^{262}$ The Court thus recognized Congress's power to tax without apportionment the gross proceeds realized in a transaction involving property both before and after Pollock, and without regard to the 16th Amendment. In essence, what was left of Pollock at the time the 16th Amendment was adopted was a restriction on imposing broad taxes on unrealized income from property - for the events that trigger realization also, generally, constitute activities that could be taxed as duties or excises. Under its historical Article I power, as repeatedly recognized both before and after Pollock, Congress had the constitutional power to tax without apportionment Ms. Murphy's damages award because it was the result of an activity - a sale of her lost human capital interest for cash.

There are a few Supreme Court cases that are often cited for the general proposition that a recovery of capital cannot constitutionally be taxed. The Supreme Court's famous decision in Eisner v. Macomber, ${ }^{263}$ discussed in detail below, ${ }^{264}$ is sometimes mis-cited as a decision prohibiting the taxation of capital. But Macomber only dealt with taxing what the Court determined to be unrealized income - a pure stock dividend that only resulted in additional pieces of paper to reflect the same ownership as before. Ironically, Macomber, by converting realization into a constitutional imperative, may have rendered the 16th Amendment entirely moot, because the Court had repeatedly recognized before the 16th Amendment that realized income resulting from an activity, such as a sale or exchange, could be taxed without apportionment as a duty or excise. ${ }^{265}$ Macomber never questioned Congress's ability to tax the entire proceeds from a sale or exchange transaction, without apportionment, as a "duty or excise" under Article I. The quick retreat from Macomber concerning whether realization was constitutionally mandated suggests there should be little concern that the Court will expand Macomber's reach. $^{266}$

\footnotetext{
${ }^{257}$ See Veazie Bank v. Fenno, 75 U.S. 533 (1869), discussed supra beginning at note 154.

${ }^{258}$ Scholey v. Rew, 102 U.S. 586 (1880), discussed supra beginning at note 159.

${ }^{259}$ See discussion supra in Part IV.A(4) beginning on page 33, and Part IV.A(5) beginning on page 39.

${ }^{260}$ Knowlton v. Moore, 178 U.S. 41 (1900), discussed supra beginning at note 200.

${ }^{261}$ Thomas v. United States, 192 U.S. 363 (1904), discussed supra beginning at note 215.

${ }^{262}$ Spreckels Sugar Refining Co. v. McClain, 192 U.S. 397 (1904), discussed supra beginning at note 212.

${ }^{263} 252$ U.S. 189 (1920).

${ }^{264}$ See infra beginning at note 354 .

${ }^{265}$ See discussion supra beginning at note 221

${ }^{266}$ See discussion supra beginning at note 393. Note also that Congress has imposed a number of taxes on unrealized income, most notably on imputed interest earned annually but only paid upon maturity of an interest under the so-called original issue discount rules (see IRC § 1272), and the requirement of mark-tomarket accounting for dealers in securities and parties involved in hedging transactiosn (See IRC § 475; 1256).
} 
The other case that is often cited for the proposition that Congress cannot tax capital is Doyle v. Mitchell Bros. Co., ${ }^{267}$ which did not consider the constitutional issue. Even reading Doyle broadly to express a definition of income that was incorporated into the 16th Amendment does not address the alternative theory for Congress's constitutional authority in Article I for taxing transactions and activities as duties and excises without apportionment.

Finally, there is one troubling Macomber era case that lends support to the notion that Congress lacks the power to tax capital. The case is Edwards v. Cuba Railroad Co., ${ }^{268}$ in which the Court held that subsidy payments made by the government of Cuba to induce development of railroad lines in that country were not income, but rather the recovery of capital, and therefore the payments could not be taxed under the 16th Amendment. There was little in the way of reasoning in the case. The Court did not consider the alternative constitutional bases for Congress to tax the transaction that generated the subsidy payments under Article I as duties and excises, because Congress had not sought to do so. In fact, the entire constitutional discussion in Cuba Railroad was inappropriate because the Court failed to first determine, as a matter of statutory law, whether Congress had in fact sought to tax the subsidy payments. Presumably, if the subsidy payments did not, as the Court held, constitute income, then Congress had in fact not sought to tax them in the statute. The Court could easily have avoided the constitutional question by ruling that the statute did not reach the subsidy payments. Despite the opinion's obvious shortcomings, the Court's suggestion in Cuba Railroad that Congress lacks the constitutional power to tax capital would lend some support, however dubious, to the notion that capital cannot constitutionally be taxed.

Although Cuba Railroad has never been directly overturned, its continuing validity is in great doubt. The opinion was issued at a time in which income was defined as a gain from capital, labor or both combined. By 1943, the Court was already having some doubts about the Macomber definition of income. In Detroit Edison Company v. Commissioner, ${ }^{269}$ the Court considered whether an electric company that received from its customers the funds necessary to construct certain power plants could take depreciation deductions. In explaining why the funds received by the electric company from its customers for the construction of the plants had not been treated as income, the Court stated: "They [the customer construction funds] have not been taxed as income, presumably because it has been thought to be precluded by this Court's decisions in Edwards v. Cuba R. Co. holding that under the circumstances of that case a government subsidy to induce railroad construction was not income." 270 Because the funds were not taxed, and thus the electric company had no basis in the power plant, the Court held that depreciation deductions could be denied. The Court's language in Detroit Edison suggested some question about the continuing validity of Cuba Railroad. One would think that the Court's expanded definition of "income" later adopted in Glenshaw Glass $^{271}$ would have effectively overruled the Cuba Railroad as a constitutional doctrine..

\footnotetext{
267247 U.S. 179 (1918), discussed supra beginning at note 292.

268268 U.S. 628 (1925).

269319 US 98 (1943).

${ }^{270} \mathrm{Id}$. at 103 (citation omitted).

271348 U.S. 426 (1955), discussed infra at note 402.
} 
With the exception of the weakly reasoned early opinion in Cuba Railroad, the existing authorities suggest that Congress could constitutionally tax the entire proceeds from the sale or exchange of property without apportionment, even though there would be no "gain" or "income" realized in the transaction. ${ }^{272}$

As is discussed below, ${ }^{273}$ Congress created a basis tracking system to prevent the double taxation of already-taxed (or exempted) financial capital. The basis system carries out Congress's policy of taxing income earned by a particular taxpayer only once at the time of realization. Congress's decision to tax only the gain from property cannot be interpreted to limit Congress's earlier power under Article I of the Constitution to tax entire transactions without regard to the recovery of basis. Therefore, even if Ms. Murphy's human capital were to be treated in the same way as previously-taxed financial capital, Congress would have the power under Article I to tax as a duty or excise, without apportionment, the entire proceeds Ms. Murphy received when she sold her emotional distress damages for cash. This would be so even if Ms. Murphy had basis in her human capital equal to the amount of the award. As is discussed below, however, what we today call human capital has not been treated by the courts in the same way as financial capital, ${ }^{274}$ and Ms. Murphy did not have any basis in her human capital and therefore her entire award was "income" within the meaning of the 16th Amendment. ${ }^{275}$ Congress had the power under Article I of the Constitution to tax Ms. Murphy's award even interpreting the principle of human capital in a way most favorable to Ms. Murphy's position.

\section{(b) Congress Could Tax Ms. Murphy's Human Capital.}

The second reason for treating Ms. Murphy's award as a "duty or excise" rather than a direct tax is that taxes on human capital have never been considered direct taxes. Prior to Pollock, the Court had suggested that only taxes on land, slaves, capitation or poll taxes, and possibly taxes on entire estates by general list were direct, ${ }^{276}$ while taxes on "personal property, contracts, occupations and the like",277 were regarded as indirect. In Pollock, the Court held that taxes on real and personal property were direct, but that taxes on "business, privileges, or employments" were not. ${ }^{278}$ Thus, throughout the long history of taxation, the Court has never suggested that a tax on human capital, other than

\footnotetext{
${ }^{272}$ It is worth noting that the constitutional amendment allows the taxation of all income, not just net income. Although the "accession to wealth" notions used by the Supreme Court in defining income suggest that only gains, computed after deducting basis, would be taxable (see Glenshaw Glass, infra at note 402), the Amendment itself is silent on the point. Of course, one could argue that the notion of "gain," being an essential element of income from the interpretations made of earlier statutes, was incorporated into the 16th Amendment's meaning. These debates are irrelevant so long as Congress seeks to tax only gain from the sale of property.

${ }_{273}$ See discussion infra Part IV.B(4) beginning on page 66.

274 See discussion infra Part IV.A(6)(b) beginning on page 45.

${ }^{275}$ See discussion infra Part IV.B(5) beginning on page 71.

${ }^{276}$ See Hylton v. United States, 3 U.S. 171, 172 (1796), discussed supra beginning at note 129; Veazie Bank v. Fenno, 75 U.S. 533, 543 (1869), discussed supra beginning at note 154; Scholey v. Rew, 90 U.S. 331 (1875), discussed supra beginning at note 159; and Springer v. United States, 102 U.S. 586 (1880), discussed supra beginning at note 161.

277 Veazie, 75 U.S. at 543.

${ }^{278}$ Pollock v. Farmers' Loan \& Trust, 158 U.S. 601, 635, discussed supra beginning at note 170.
} 
a head or capitation tax which is specifically mentioned in the Constitution (and is not imposed on human capital but on human beings regardless of potential), ${ }^{279}$ is direct. Indeed, the Court consistently recognized, even in Pollock, that Congress has the unfettered ability to tax wages. And wages are, after all, simply receipts from the sale of human capital. $^{280}$ If taxes on human capital were treated the same way under the Constitution as taxes on financial capital, then the Court's distinction in Pollock between income from real and personal property (held to be direct), and income from employments (held to be indirect) would be erroneous, since both would constitute income from "capital." The Court and Congress have not treated what we today call "human capital" in the same way as financial capital, ${ }^{281}$ and the Court has never questioned Congress's ability to tax without apportionment income from the sale of human capital. Since the tax on Ms. Murphy's damages award was not a tax on real or personal property, but at best a tax on human capital which has never been treated as real or personal property, ${ }^{282}$ there should have been no constitutional limitation on Congress's power to tax it without apportionment.

Therefore, both because Congress has the unlimited power to tax transactions involving the sale of any form of capital without apportionment, and because human capital has never been treated as financial capital or property for the purpose of taxation, Congress had the power to tax Ms. Murphy's damages award even if it did not constitute "income" within the meaning of the 16th Amendment.

By wrongly focusing on the 16th Amendment as the sole source of Congress's taxing power, the court of appeals in Murphy failed to consider Congress's original grant of power contained in Article I of the Constitution, by which it could tax Ms. Murphy's award irrespective of whether it constitutes "income" within the meaning of the 16th Amendment. Moreover, by treating human capital in the same way as financial capital for purposes of the 16th Amendment, the court of appeals in Murphy has opened a Pandora's box, raising questions about the constitutional validity of taxes on such firmly established sources as wages. ${ }^{283}$ That box can be easily closed through proper analysis, returning tax policy to the Congress where it belongs.

B. Congress Had the Power to Tax Ms. Murphy's Damages Award Under the 16th Amendment.

(1) The Court of Appeals' Holding in Murphy.

\footnotetext{
${ }^{279}$ A capitation or head tax is imposed on each human being regardless of the value of the human being's human capital. Even if human capital were to be treated as property, a tax on the increase in the value of human capital would be a tax on income just as a tax on the increase in the value of property would be a tax on income. The concept of human capital suggests treating the human being as a value store, consisting of future potential revenues that the human being is able to generate. Even if human capital were to be equated with financial capital, under both the pre-Pollock and post-Pollock cases Congress could tax as an duty or excise, without apportionment, any sale or exchange of human capital for other property.

${ }^{280}$ See discussion infra Part IV.B(5) beginning on page 71.

${ }^{281}$ See discussion infra at Part IV.A(2) beginning at page 24.

${ }^{282}$ See discussion infra at Part IV.B(5) beginning at page 55.

${ }^{283}$ See discussion infra at Part IV.B(5) beginning at page 71 regarding the consequences of constitutionally mandating Congress to treat human capital as financial capital.
} 
The court of appeals in Murphy concluded that Ms. Murphy's award of emotional and reputational damages was not "income" within the meaning of the 16th Amendment because it involved a "restoration of capital." In support of this statement, the court of appeals relied on two 1918 Supreme Court cases, Doyle v. Mitchell Bros., Co, and S. Pac. Co. v. Lowe, for the proposition that a "return of capital [is] not income under [the] IRC or Sixteenth Amendment."284 In addition, the court of appeals agreed with Ms. Murphy's argument that two 1918 administrative opinions, "strongly suggest that the term 'incomes' as used in the Sixteenth Amendment does not extend to monies received solely in compensation for a personal injury unrelated to lost wages or earnings." 285 The court of appeals then concluded that both physical and non-physical awards were not "income" within the 16th Amendment, and the attempt by Congress to tax non-physical awards was therefore unconstitutional. ${ }^{286}$

In reaching these conclusions, the court of appeals failed to put these materials in their proper historical context or to correctly interpret their holdings. A proper analysis of the cited materials in the light of their historical context will show that none of these materials was inferring a constitutional limitation on Congress's taxing power. Rather, the materials were attempting to apply then-recent Supreme Court interpretations of the applicable tax acts, not the Constitution. These early Supreme Court statutory (and later Constitutional) interpretations have long since been rejected or limited. A proper understanding of the historical materials cited by the court of appeals in Murphy requires careful chronological review of tax history. A careful in-context review of these materials will show that they do not support the court of appeal's conclusion that the enactors of the 16th Amendment intended human capital recoveries to be beyond the reach of Congress's income taxing power. Moreover, under modern interpretations of Congress's taxing power under the 16th Amendment, Ms. Murphy's award would constitute "income" because she realized an accession to her financial wealth.

\section{(2) The Historical Meaning of "Income" Under the 16th Amendment Before Macomber.}

Each of the American taxing statutes have taxed income on an annual basis. In order to do so, it has been necessary to determine how increases in property value accruing over a period of time would be taxed. There are two fundamentally different types of income tax systems for determining in what year income from property will be taxable: (1) tax the increase in the value of property accruing on an annual basis, regardless of whether the property has been sold or the improvement in value has been severed from the property in some way (hereafter, the "annual accrual system"), or (2) do not tax the annual increase, but instead tax the entire increase in value at the time of realization - either when the gain is severed in some way from the property, such as upon

\footnotetext{
${ }^{284}$ Murphy, 460 F.3d at 85.

${ }^{285} I d$. at 90.

${ }^{286}$ Id. at 92 ("the framers of the Sixteenth Amendment would not have understood compensation for a personal injury - including a nonphysical injury - to be income.”).
} 
sale, exchange or other disposition of the property, or when some other recognized event of realization occurs (hereafter, the "realization system"). ${ }^{287}$

The annual accrual system is difficult to administer because any increase in the value of property must be estimated, since there is no market-based event that establishes the value. In addition, an accrual system can work financial hardships on the owners of property who, prior to sale or other realization event, will have received no money from the property with which to pay the tax. The main drawbacks of the realization system are (1) the need to clearly define the realization event, (2) the ability of taxpayers to defer paying taxes on income from the time it accrues until the realization event occurs, and (3) the problem of bracket creep - taxing income accruing during multiple tax years in the single year of realization.

There is nothing in the text of the 16th amendment that would eliminate the apportionment requirement only for one type of income tax system but not the other. Moreover, both types of income taxation systems had been utilized in the United States prior to the adoption of the 16th Amendment. The annual accrual system appears to have been utilized in the first federal income tax act which was adopted during the Civil War, according to the Court in Gray v. Darlington. ${ }^{288}$ The taxpayer in Darlington bought United States Treasury Notes before 1865, exchanged the Notes for United States Treasury Bonds in 1865, and sold the Bonds in 1869 for a profit of $\$ 20,000$ over the original cost of the Notes. The issue was whether that entire profit, accruing over more than four years, two of which were prior to the enactment of the taxing act, would be taxed in the year of sale. The Court, interpreting the language of the 1867 Act requiring the tax to be "levied, collected, and paid annually," held that only the increase in value attributed to the tax year was taxable under the statute.

Similarly, in Collector v. Hubbard, ${ }^{289}$ a shareholder objected to being taxed on the corporation's income that had not been severed or paid as dividends. The 1864 Act required all corporate income, whether distributed or not, to be included in the shareholder's income subject to tax. ${ }^{290}$ Although the case was decided on procedural grounds, the Court stated, apparently in dicta, that the undistributed corporate profits should have been included in income. ${ }^{291}$ The Court in Hubbard made no mention of the Constitution, ruling entirely on the basis of the statutory language.

\footnotetext{
${ }^{287}$ There is a third potential system, which would look at final results of investments rather than annual receipts, although this system has never been utilized by American courts, except in a particular transaction where there is no administrative way to determine the gain to tax. See Philadelphia Park Amusement Co. $v$. United States, 126 F. Supp. 184 (1954) (holding that open transaction doctrine following exchange of property should only apply in the "rare and extraordinary cases that the value of the property exchanged cannot be ascertained with reasonable certainty.").

28882 U.S. 63 (1872).

28979 U.S. 1 (1871).

${ }^{290}$ Internal Revenue Act of June 30th, 1864, § 117, 13 Stat. 281 ("And the gains and profits of all companies, whether incorporated or partnership, other than the companies specified in this section, shall be included in estimating the annual gains, profits, or income of any person entitled to the same, whether divided or otherwise.")

29179 U.S. at 28 ("Suppose, however, that . . . the provision in question is not a bar to the present suit, still the court is of the opinion that the addition made to the list rendered by the plaintiff [for undistributed corporate profits] was proper, that the tax was lawfully assessed, and that the plaintiff is not entitled to recover in this case.").
} 
On the other hand, the Court in Doyle v. Mitchell Bros. Co., ${ }^{292}$ recognized that the realization system applied under the 1909 Corporate Income Tax Act. Doyle was decided under the 1909 Act after the enactment of the 16th Amendment, but concerned years before the Amendment. The Court in Doyle assumed without analysis that all of the income accruing from the time of enactment of the Act - 1909 - until the date of sale was subject to tax at once in the year of sale. The main issue of contention in Doyle, however, was whether the increase in the value of assets accruing prior to the 1909 Act but realized after the enactment of the 1909 Act would also be included in income in the year of realization. The Court, noting that part of the proceeds received from the sale of property is attributable to the recovery of original cost, and part in the receipt of gain (if the sale is for more than cost) or incurrence of loss (if the sale is for less than cost), first noted that only the gain from property should be included in the concept of "income" under the 1909 Act. The Court stated that this rule - that "income" only constitutes the gain realized from the sale of property, and not the entire proceeds of sale - "has been recognized from the beginning [of the 1909 Corporate Tax] by the administrative officers of the Government." 293 The Court went on to interpret the 1909 Act to impose a tax only on income accrued after 1909. The value of property on the date of the enactment of the 1909 Act, even if in excess of cost, would be deducted from the sale proceeds in determining the gain or income realized in the year of sale. ${ }^{294}$ Doyle was decided entirely on the grounds of statutory construction, and did not consider the meaning of the 16th Amendment of the Constitution (which indeed had no application to the case). There was also no suggestion in the opinion that Congress lacked the Constitutional power to tax income in the year of sale attributed to periods before enactment of the Act.

Doyle has been regularly cited by subsequent courts for its quotation from the Stratton's case, defining income as a "gain from capital or labor or from both combined." 295 In both cases, the Court was defining income for the purpose of determining whether the tax was an excise on business activity, as was required by the statute in both cases. The constitutionality of the 1909 Act had, after all, been upheld by distinguishing Pollock on the grounds that the 1909 Act had a business activity requirement. Whether this definition of income should have been applied under the 16th Amendment, which allowed the taxation of income without apportionment irrespective of business activity, would be an issue of debate until the mid 1950s, when the Supreme Court ruled that the old definition was not a touchstone for the meaning of income. ${ }^{296}$ The Court in Doyle also noted that the government did not challenge the method utilized by the taxpayer for allocating income between the pre-1909 period and the post-1909

\footnotetext{
292247 U.S. 179 (1918).

${ }^{293}$ Id. at 185 .

${ }^{294} \mathrm{Id}$. at 187 . In describing the gain from sale, the Court noted that the assets had not increased in value on their own, but had increased in value through processing during the year. The Court stated: There having been no change in market values during these years, the deduction did but restore to the capital in money that which had been withdrawn in stumpage cut, leaving the aggregate of capital neither increased nor decreased, and leaving the residue of the gross receipts to represent the gain realized by the conversion, so far as that gain arose while the act was in effect. This was in accordance with the true intent and meaning of the act." $I d$. at 188. The Court thus used the word "realized" to represent the increase in value reduced to money at the time of sale.

${ }^{295}$ See supra note 224, quoted in Doyle, 247 U.S. at 185.

${ }^{296}$ See discussion of Commissioner v. Glenshaw Glass Co., 348 U.S. 426 (1955), infra note 402.
} 
period. ${ }^{297}$ The court of appeals' suggestion in Murphy that Doyle had interpreted the meaning of the 16th Amendment ${ }^{298}$ is simply incorrect.

In Hays v. Gauley Mountain Coal Co., ${ }^{299}$ the Court again held that the language used by Congress in the 1909 Act, unlike the language used by Congress in the 1869 Act that had been interpreted by the Court in Darlington, ${ }^{300}$ showed an intent to tax all of the income from property in the year of sale, rather than on an annual basis when it accrued at least to the extent that it accrued after enactment of the Act in 1909. The Court stated:

The expression "income received during such year," employed in the Act of 1909 , looks to the time of realization rather than to the period of accruement, except as the taking effect of the act on a specified date (January 1, 1909), excludes income that accrued before that date. ${ }^{301}$

Thus was borne the formal concept of "realization," which began as a matter of statutory construction of the 1909 Corporate Income Tax Act. ${ }^{302}$

The broad 1913 income tax, enacted after the adoption of the 16th Amendment, used language more similar to the Civil War Income Tax than the 1909 Corporate Tax, covering all income "arising or accruing" during the year. ${ }^{303}$ The 1913 statute did not specify whether an accrual system or realization system would apply. ${ }^{304}$

However, despite the vague language of the statute, the Court promptly interpreted the language to adopt a realization system. In Towne v. Eisner, ${ }^{305}$ the Court

297247 U.S. at 188.

${ }^{298}$ Murphy, 460 F.3d at 85.

299247 U.S. 189 (1918).

${ }^{300} I d$. at 191 ("Gains, profits, and income for the year ending the thirty-first day of December next preceding" (Act of 1867) conveys a different meaning from "the entire net income . . . Received by it ... during such year" (Act of 1909).”).

${ }^{301} I d$. at 192 (emphasis added).

${ }^{302}$ The cases were not consistent in the method for computing gain attributed to the post-1909 period. In Doyle, the gain was based on the difference between the sale price of the processed timber and its unprocessed value at the time the 1909 act went into effect. Doyle, 247 U.S. at 188. In Hays, Court upheld that government's assessment of a pro-rata portion of the gain allocated pro rata on the basis of time. The taxpayer in Hays had purchased stock for $\$ 800,000$ in 1902 , and sold the stock for $\$ 1,010,000$ in 1911 , realizing a total profit of $\$ 210,000$. The taxpayer had owned the stock for a total of 3,233 days, and the sale occurred 1019 days after the enactment of the 1909 Act. Therefore, the government computed the tax proportionally on the basis of time: $(1,019 / 3,233) \mathrm{X} \$ 210,000=\$ 66,189.30$. Hays, 247 U.S. at 190. In $S$. Pac. Co. v. Lowe, 247 U.S. 330, 335 (1918), the court used the Doyle approach, by accepting the stipulated value for stock at the beginning of 1909 as the basis for determining gain.

${ }^{303}$ Compare supra note 300 with Act of October 3, 1913, c. 16, 38 Stat. 114, 116 ("There shall be levied, assessed, collected and paid annually upon the entire net income arising or accruing from all sources in the preceding calendar year ... a tax of 1 per centum per annum upon such income.").

${ }^{304}$ For example, the statute said that the additional tax "shall embrace the share to which he [the taxpayer] would be entitled of the gains and profits, if divided or distributed, whether divided or distributed or not, of all corporations ... or associations however created or organized, formed or fraudulently availed of for the purpose of preventing the imposition of such tax through the medium of permitting such gains or profits to accumulate instead of being divided or distributed." Id. It also covered income from "sales or ownership or use of or interest in real or personal property, also from interest, rent, dividends, securities". Id. at 167. ${ }^{305} 245$ U.S. 418 (1918). 
held that a stock dividend ${ }^{306}$ did not create a realization event for the shareholder under the 1913 Act. Justice Holmes, writing for a unanimous court, made two important statements in the Towne opinion. First, the Court stated that the 1913 Act's definition of "income" may not be the same as the definition of "income" in the 16th Amendment. 307 The idea that "income" had the same meaning in the statute and the 16th Amendment first occurred in the 1920 decision in Eisner v. Macomber. ${ }^{308}$ The court of appeals in Murphy cited Macomber for the a synonymous reading of "income," and suggested that the Macomber analysis should be respected because it has been "acquiesced in for a long term of years." 309 However, as discussed below, ${ }^{310}$ Macomber did not say that the two terms were synonymous, but only that Congress intended to exert its full taxing power.

Second, the Court in Towne held that the 1913 Act did not reach the taxpayer's stock dividend, because neither the shareholder nor the corporation received any separate gain from the distribution of the additional shares. ${ }^{311}$ The Court did not base its decision on an interpretation of the 16th Amendment, but rather relied on an interpretation of the

\footnotetext{
${ }^{306}$ A pure stock dividend is a pro-rata distribution of additional stock to all shareholders. For accounting purposes, a corporation declaring a stock dividend must transfer amounts showing as earnings on its balance sheet to paid-in-capital. On the corporation's books, the transaction looks the same as a cash dividend, followed by a subsequent purchase by the shareholders with their cash dividends of additional stock. From the shareholder's prospective, the shareholder owns more shares of stock, having less value per share, resulting in no change in actual ownership. For example, assume a corporation with 10,000 shares of stock outstanding declared a $100 \%$ stock dividend. A shareholder owning $10 \%$ of the corporation (1,000 shares) before the dividend would continue to own $10 \%$ of the corporation $(2,000 / 20,000)$ after the dividend distribution. While no real gain is realized by a shareholder from the mere receipt of a stock dividend, the question considered by the Court is whether this stock dividend was an event that would trigger the shareholder's requirement to realize and recognize the gain inherent in the stock (at least to the extent reflected in the pro forma distribution of the corporation's earnings, and the mandatory reinvestment of those earnings in the stock).

${ }^{307} I d$. at 425 ("The Government in the first place moves to dismiss the case for want of jurisdiction, on the ground that the only question here is the construction of the statute not its constitutionality. It argues that if such a stock dividend is not income within the meaning of the Constitution it is not income within the intent of the statute, and hence that the meaning of the Sixteenth Amendment is not an immediate issue, and is important only as throwing light on the construction of the act. But it is not necessarily true that income means the same thing in the Constitution and the act.") (emphasis added). ${ }^{308} 252$ U.S. 189 (1920).

${ }^{309}$ The court of appeals first quoted Myers v. United States, 272 U.S. 52, 175 (1926), for the proposition that "a contemporaneous legislative exposition of the Constitution ... acquiesced in for a long term of years, fixes the construction to be given to its provisions." Murphy, 460 F.3d at 90. The Court then quotes from Eisner v. Macomber for the proposition that "construction of the [Revenue Act of 1913] is inseparable from the interpretation in the Sixteenth Amendment." Id. The Court concludes that it must inquire into what "the people when they adopted the Sixteenth Amendment, or the Congress when it implemented the Amendment, would have understood compensatory damages for a nonphysical injury to be income." Id. In light of the deference to early interpretations, one wonders why the Court would adopt Macomber's statement suggesting that income in the Constitution was synonymous with income in the 1913 Act, rather than the earlier statement in Towne suggesting that the words may not be synonymous.

${ }^{310}$ See discussion infra at notes 359 and 389.

${ }^{311}$ Id. at 427 ("A stock dividend really takes nothing from the property of the corporation, and adds nothing to the interests of the shareholders. Its property is not diminished, and their interests are not increased. . . The proportional interest of each shareholder remains the same. The only change is in the evidence which represents that interest, the new shares and the original shares together representing the same proportional interest that the original shares represented before the issue of the new ones." In short, the corporation is no poorer and the stockholder is no richer than they were before.") (citations omitted).
} 
1913 Act. Indeed, the author of the opinion in Towne, Justice Holmes, would later dissent in Macomber from the effort to constitutionalize the ruling. ${ }^{312}$

In 1918, the Court issued on the same day four tax opinions that would greatly confuse tax jurisprudence. In the main case, Lynch v. Hornby, ${ }^{313}$ the Court held that the 1913 Act could reach income accrued by a corporation before the Act but paid as dividends after the Act. "We repeat that under the 1913 Act dividends declared and paid in the ordinary course by a corporation to its stockholders after March 1, 1913, whether from current earnings or from a surplus accumulated prior to that date, were taxable as income to the stockholder." 314 The decision was of limited importance, because by the time the Court issued the opinion Congress had already exempted income earned before 1913 from taxation in the 1916 and 1917 Acts. ${ }^{315}$ Nevertheless, the decision constituted a broad view of Congress's new taxing power.

But the broad reading of the 1913 Act in Hornby was confusingly restricted in the second companion case, Lynch v. Turrish, ${ }^{316}$ where a shareholder received in 1914 a liquidating distribution in cash from a corporation. The liquidating distribution represented twice the original cost of the shareholder's stock, and was the result of the gradual appreciation in the value of the corporation's timberland. The shareholder argued that the increase in the value of assets over many years should not be taxable in entirety in the year of sale, citing Gray v. Darlington. ${ }^{317}$ The Court agreed with the taxpayer, and stated broadly that the profit accrued in prior years from the increase in the market value of assets was not "income" but rather "capital" under the Act. ${ }^{318}$ The Court did not mention Hornby, apparently because it dealt with a dividend rather than a liquidating distribution. The distinction between Hornby and Turrish hinged on the language of the taxing statute, not upon any constitutional limitation on the power of Congress to impose taxes. In Hornby, Congress specifically provided in the taxing statute that dividends, regardless of source, would be treated as income, while in Turrish no such specific language was included with respect to gains from increases in the value of property upon liquidation. Nevertheless, the loose language in Turrish would later lead to constitutional challenges to Congress's ability to tax capital gains. ${ }^{319}$

\footnotetext{
312 See infra at note 368 .

313247 U.S. 339 (1918).

${ }^{314} \mathrm{Id}$. at 346.
}

315252 U.S. at 346 n. 1 ("In Act of September 8, 1916, c. 463, 39 Stat. 756, 757, which took the place of the Act of 1913 . . . 'Provided, That the term 'dividends' as used in this title shall be held to mean any distribution made or ordered to be made by a corporation ... out of its earnings or profits accrued since March first, nineteen hundred and thirteen, and payable to its shareholders, whether in cash or in stock of the corporation."'). The 1917 Act incorporated a similar proviso, but provided that dividends are first deemed to come from the most recent income (Id.), a provision that remains in the law today. See IRC $\S$ $316(\mathrm{a})$.

316247 U.S. 221 (1918).

${ }^{317}$ See discussion supra at note 288.

${ }^{318}$ Lynch v. Hornby, 247 U.S. at 231 ("The mere fact that property has advanced in value between the date of its acquisition and sale does not authorize the imposition of a tax on the amount of the advance. Mere advance in value in no sense constitutes the gains, profits, or income specified by the statute. It constitutes and can be treated merely as increase of capital.").

${ }^{319}$ See discussion of Merchant's Loan \& Trust Co. v Smietanka, 255 U.S. 509 (1921), discussed infra beginning at note 379 . 
In the third companion case, Southern Pacific Company v. Lowe, ${ }^{320}$ the Court made a fine distinction of Hornby. Hornby permitted the taxation of dividends paid after enactment of the 1913 Act from income earned both before and after the Act, but Hornby would not apply to dividends paid after enactment of the 1913 Act from income that had been earned entirely before the Act - at least where a single shareholder had total control of the corporation. ${ }^{321}$ The Court ignored the corporate form set up by the taxpayer to treat the income, distributed to the taxpayer in the form of dividends after the 1913 Act, as if earned by the taxpayer before the 1913 Act was adopted.

Interestingly, the court of appeals in Murphy cited Lowe (along with Doyle) ${ }^{322}$ as holding that a "return of capital is not income under [the] IRC or Sixteenth Amendment." 323 Both citations are erroneous. The Court in Lowe did not discuss whether a return of capital was income under the 16th Amendment. The only mention in the opinion of the 16th Amendment concerned the date of its enactment. One could argue that Lowe implied that Congress might not be able to tax income earned by an owner of property before the effective date of the statute, although a careful reading of the opinion makes no such suggestion (and the theory would seem inconsistent with the Court's contemporaneous holding in Hornby). ${ }^{324}$

In the final companion case, Peabody v. Eisner, ${ }^{325}$ the Court made clear that Towne v. Eisner was limited to stock dividends of the issuing corporation, and would not apply to dividends made in the form of cash or corporate assets such as stock in other companies. In Peabody, the Court held that cash or property dividends are always taxable as income.

It was after this series of confusing 1918 judicial opinions, especially the opinion in Turrish which caused some to believe that capital gains might not be "income" at all under the Act, that the 1918 Attorney General opinion and Treasury Department Decision, which were relied on by the court of appeals in Murphy, were issued. At the time, the concept of realization and the method for determining cost basis were in their early development. The Court had repeated a definition of income - "gain derived from capital, from labor, or from both combined"326 - that had been used in the 1909 Acts to

\footnotetext{
${ }^{320} 247$ U.S. 330 (1918).

${ }^{321}$ Id. at 336-37 ("Our view of the effect of this act upon dividends received by the ordinary stockholder after it took effect but paid out of a surplus that accrued to the corporation before that event, is set forth in Lynch $v$. Hornby . . . We base our conclusion in the present case upon the view that it was the purpose and intent of Congress, while taxing "the entire net income arising or accruing from all sources" during each year commencing with the first day of March, 1913, to refrain from taxing that which, in mere from only, bore the appearance of income accruing after that date, while in truth and in substance it accrued before; and upon the fact that the Central Pacific and the Southern Pacific were in substance identical because of the complete ownership and control which the latter possessed over the former, as stockholder and in other capacities.") (citations omitted).

${ }^{322}$ See supra beginning at note 292 .

${ }^{323}$ Murphy, 460 F.3d at 85.

${ }^{324}$ Lowe, 247 U.S. at 334-35 ("The purpose to refrain from taxing income that accrued prior to March 1, 1913, and to exclude from consideration in making the computation any income that accrued in a preceding calendar year, is made plain by the provision last referred to [the statutory language]; indeed, the Sixteenth Amendment, under which for the first time Congress was authorized to tax income from property without apportioning the tax among the States according to population, received the approval of the requisite number of States only in February, 1913.") (emphasis added).

325247 U.S. 347 (1918).

${ }^{326}$ See supra notes 231, 295.
} 
distinguish between profits from corporate activity that could be taxed as an excise without apportionment, and mere unrealized increases in the value of property that, under Pollock, could not be taxed without apportionment. ${ }^{327}$

Contrary to the suggestion made by the court of appeals in Murphy, none of the Supreme Court's opinions before 1920 had suggested that Congress lacked the power to tax capital under the 16th Amendment. Rather, all of the Court's opinions had focused on the language and intent of the taxing statutes. In addition, the Court in Towne v. Eisner had flatly rejected the contention that the word "income" under the 1913 Act and under the 16th Amendment were necessarily synonymous. While constitutional questions had been raised by the parties, the Court had carefully sidestepped the constitutional issues.

The court of appeals in Murphy relied heavily on a 1918 Attorney General Opinion $^{328}$ and a 1918 Treasury Decision ${ }^{329}$ to support its theory that the enactors of the 16th Amendment did not intend for damage awards in compensation for losses of human capital to be included within the definition of income. ${ }^{330}$ However, neither of these administrative materials support the court of appeals' theory, as neither purported to determine the meaning of income under the 16th Amendment.

The Attorney General's 1918 opinion considered whether the proceeds of an accident insurance policy would be taxable under the 1916 and 1917 Acts. The General noted that the Court in Stratton and Doyle had defined income under the 1909 Act as "gain derived from capital, from labor, or from both combined," and that the court of appeals' decision in Doyle, ${ }^{331}$ which had been affirmed by the Supreme Court, ${ }^{332}$ had suggested in dicta that insurance proceeds received in compensation for damages to property should not constitute income under the 1909 Act because the insured loss could not be deducted under the Act. ${ }^{333}$ The General then concluded that:

Assuming that this dictum [from Doyle regarding property damage insurance proceeds] is a correct construction of the act ... it follows that if the proceeds of such accident insurance are held to be "income", they are in a category different from the proceeds of any other kind of insurance. In my opinion the act does not make such a distinction, because the proceeds of an accident insurance

\footnotetext{
${ }^{327}$ See discussion supra at note 231.

32831 Op. Att'y Gen. 304 (1918).

${ }^{329}$ T.D. 2747,20 Treas. Dec. Int. Rev. 457 (1918).

${ }^{330}$ Murphy, 460 F.3d at 90 ("We concur in Murphy's view, however, that the Attorney General's 1918 opinion and the Treasury Department's ruling of the same year strongly suggest that the tem "incomes" as used in the Sixteenth Amendment does not extend to monies received solely in compensation for a personal injury and unrelated to lost wages or earnings.").

${ }^{331}$ Doyle v. Mitchell Bros. Co., 235 F. 686, 688 (6th Cir. 1916), aff'd 247 U.S. 179 (1918) ("Fire insurance money is clearly a substitute for the assets burned; but we find that in case of a fire loss uninsured the loss may be deducted from income, while if it is insured, and if the insurance money is "income," the loss may not be deducted, and the insurance money must be added -- an absurdity which can be avoided only by saying that such insurance money is not income at all. The proceeds of the sale of a building or other permanent assets are as clearly a substitute therefor as is the insurance money paid to indemnify for a building burned.").

${ }^{332}$ See discussion supra beginning at note 292.

${ }^{333} \mathrm{Id}$.
} 
policy are not "gains or profits and income" as these terms are defined by the Supreme Court. ${ }^{334}$

The General thus explicitly based his opinion on the judicial interpretations of the applicable statutes, and not on the enactors' understanding of the meaning of "income" under the 16th Amendment. ${ }^{335}$ Contrary to the court of appeals' suggestion in Murphy, the General's 1918 opinion, which was issued five years after the 16th Amendment was adopted, was based on the General's statutory interpretations in light of the Court's recent statutory interpretations. The General did not purport to interpret or give an opinion concerning the scope of the 16th Amendment.

In the course of rendering his opinion, the General speculated about why, as a matter of policy, accident insurance proceeds might be excludible, suggesting the recovery was on account of capital:

Without affirming that the human body is in a technical sense the "capital" invested in an accident policy, in a broad, natural sense the proceeds of the policy do but substitute, so far as they go, capital which is the source of future periodical income. They merely take the place of capital in human ability which was destroyed by the accident. They are therefore "capital" as distinguished from "income" receipts. ${ }^{336}$

It is this statement - a statement which in modern terms would suggest that the recovery should be taxable since the payment is a substitute for "future periodical income" which would have been taxed ${ }^{337}$ - that is cited in part and out of context by the court of appeals in Murphy for the proposition that compensatory damages were not intended to be income within the 16th Amendment. But this statement had nothing to do with the 16th Amendment - it was a theory, however flawed, ${ }^{338}$ explaining why the General believed that Congress had intended in the statute to exclude accident insurance proceeds from income.

\footnotetext{
33431 Op. Att'y Gen. at 7 (emphasis added).

335 Indeed, the General did not even mention the 16th Amendment in the opinion. 31 Op. Att'y Gen. 304 (1918). See quotation from Attorney General, supra note 334.

33631 Op. Att'y Gen. 304, 308 (1918).

${ }^{337}$ See discussion of Burke v. U.S., 504 U.S. 229 (1992), supra note 61.

${ }^{338}$ The suggestion that human capital is invested in the insurance policy makes no sense. An insurance policy is purchased with premiums, generally paid in cash. These premiums are the capital invested in the policy. The potential loss of human capital is the risk that is being insured. The recovery may result in a gain if the recovery exceeds the premiums paid, or a loss if the recovery does not exceed the premiums paid. The court of appeals in Murphy conceded that the recovery of lost wages would be taxable, because the lost wages would have been taxable if earned. Murphy, 460 F.3d at 91 ("[W]e see no meaningful distinction between Murphy's award and the kids of damages recoverable for personal injury when the Sixteenth Amendment was adopted. Because, as we have seen, the term "incomes," as understood in 1913, clearly did not include damages received in compensation for physical personal injury, we infer that it likewise did not include damages received for a nonphysical injury and unrelated to lost wages or earning capacity.") (emphasis added).
} 
Similarly, the 1918 Treasury Decision cited by the court of appeals in Murphy ${ }^{339}$ simply instructed internal revenue collectors to follow the Attorney General's interpretation of the statutory enactments. ${ }^{340}$ Once again, there was no discussion in the Decision of the 16th Amendment. Curiously, the Decision only applied by its terms to an "accident" recovery, and therefore may not have even covered an emotional and reputational injury recovery like that at issue in Murphy. Therefore, a correct in-context review of the 1918 administrative materials in their proper historical context, and the wording used in them, belies the court of appeals' argument in Murphy that these materials "strongly suggest that the term 'incomes' as used in the Sixteenth Amendment does not extend to money received solely in compensation for a personal injury and unrelated to lost wages or earnings.",341

It is also important to recognize that these administrative materials, issued five years after the enactment of the 16th Amendment, were rendered under an early Supreme Court definition of income that would later be rejected by the Supreme Court. ${ }^{342}$ The interpretations are simply not evidence of the clear intent of federal and state legislators who voted for the 16th Amendment to exempt emotional distress damages from taxation as income. The quotations used by the court of appeals in Murphy were taken out of context, possibly to avoid quoting the language contained in the rulings showing their statutory, and not constitutional, genesis.

Following these 1918 opinions, Congress decided in the Revenue Act of $1918^{343}$ to exempt personal injury recoveries from income. ${ }^{344}$ The court of appeals in Murphy conceded that the scant legislative history from the 1918 Act was ambiguous as to the reason Congress enacted a specific exclusion. ${ }^{345}$ The relevant legislative history consists only of a short statement from a House committee report suggesting that "under present law it is doubtful whether amounts received through accident or health insurance, or under workmen's compensation acts, as compensation for personal injury or sickness, and damages received on account of such injuries or sickness, are required to be included

\footnotetext{
${ }^{339}$ Murphy, 460 F.3d at 90 ("We concur in Murphy's view, however, that the Attorney General's 1918 opinion and the Treasury Department's ruling of the same year strongly suggest that the term "incomes" as used in the Sixteenth Amendment does not extend to monies received solely in compensation for a personal injury and unrelated to lost wages or earnings.").

${ }^{340}$ T.D. 2747, 20 Treas. Dec. Int. Rev. 457 (1918) ("To collectors of internal revenue and others concerned: The Attorney General has advised, upon the basis of recent decisions of the Supreme Court (Doyle . .

Hornby ... Turrish ... and ... Lowe ... and it is accordingly held that the proceeds of an accident insurance policy . . . are not income taxable under the provisions of . . . act of September 8, 1916 . . act of October 3, 1917. It is held upon similar principles that an amount received by an individual as a result of a suit or compromise for personal injuries sustained by him through accident is not income taxable under the provisions of said titles.").

${ }^{341}$ Murphy, 460 F.3d at 90 (emphasis added). According to Murphy, the report merely said: "it is doubtful whether . . compensation for personal injury or sickness ... [is] required to be included in gross income. " Murphy, 460 F.3d at 86, quoting H.R. REP. No. 65-767, at 9-10 (1918).

342 See discussion of Commissioner v. Glenshaw Glass, 348 U.S. 426 (1955), infra note 402.

${ }^{343}$ Revenue Act of 1918, Pub. L. No. 65-254, 40 Stat 1057 (1919).

${ }^{344} \mathrm{Id}$. at 1065, § 213(b) (Gross income does not include the following items which shall be exempt from taxation under this title ... ("[t]he amount of any damages received whether by suit or agreement on account of such [personal] injuries or sickness.").

${ }^{345}$ Murphy, 460 F.3d. at 90 ("We agree with the Government that the House Report on the 1918 Act is ambiguous and therefore unhelpful on the question before us.").
} 
in income. 346 At best, one can surmise that Congress based its decision to exclude personal injury awards, at least in part, on the Attorney General's opinion about the current state of the law, which was itself based on statutory interpretations and not on the limits of Congressional power under the 16th Amendment. ${ }^{347}$ While Congress might well have sought to avoid a constitutional challenge by enacting an exemption, it might also have thought that the exemption was justified as a matter of policy.

The Court more recently considered these administrative materials in O'Gilvie v. United States, ${ }^{348}$ a case that asked whether Congress intended punitive damages recovered in a personal injury action to be excluded under the 1988 version of IRC section 104(a)(2), which had its genesis in the 1918 Act. The Court concluded, in part on the basis of these 1918 administrative materials, that Congress only intended to exclude compensatory damages and not punitive damages. In his dissent in O'Gilvie, Justice Scalia criticized any attempt to explain Congress's ultimate adoption of the exclusion for personal injury awards on the 1918 Attorney General's dubious and speculative "human capital" analysis. ${ }^{349}$

The court of appeals in Murphy takes this speculation one step further, by inferring a constitutional limitation from language that was, at best, explaining the Attorney General's rationale for his interpretation of the taxing statute. The court of appeals in Murphy cited no credible authority for the proposition that the enactors of the 16th Amendment understood that "income" did not include emotional distress recoveries.

The court of appeals' most glaring mistake was its failure to point out that the first treasury rulings after the adoption of the 16th Amendment treated all personal injury damages as includible in income, and taxable. ${ }^{350}$ After all, if, as the court of appeals in

\footnotetext{
${ }^{346}$ Murphy, 460 F.3d. at 86, quoting H.R. REP. No. 65-767, at 9-10 (1918). See also Laura Sager and Stephen Cohen, Discrimination Against Damages For Unlawful Discrimination: The Supreme Court, Congress, And The Income Tax, 35 HARV. J. ON LEGIS. 447, 453 n. 44 (Summer, 1998) (hereafter, Sager \& Cohen); Douglas K. Chapman, No Pain - No Gain? Should Personal Injury Damages Keep Their Tax Exempt Status?, 9 U. ARK. LiTTLE ROCK L. J. 407, 414 (1986-87).

${ }^{347}$ The Court of Appeals in Murphy, 460 F.3d. at 86, quoted the following statement from Dotson v. United States, 87 F.3d 682 (5th Cir. 1996): "Congress first enacted the personal injury compensation exclusion in 1918 at a time when such payments were considered the return of human capital, and thus not constitutionally taxable "income" under the 16th Amendment. See H.R. REP. No. 767, 65th Cong., 2nd Sess. 9-10 (1918)." There is nothing in the report that supports the statement from Dotson. The Court of Appeals in Dotson also cited in a footnote an article by Robert Ellwood, Supreme Court's Ruling on Taxation of Discrimination Damages Provides Little Resolution, 83 J. TAX'N 148, n. 3 (1995), suggesting that the human capital argument is seriously flawed. Dotson, at 685 n. 1.

348519 U.S. 79 (1996).

${ }^{349}$ Id. at 97-98 (Scalia, J., dissenting) ("The statute must exclude punitive damages because the Committee Report must have had in mind a 1918 Treasury Decision, whose text no more supports exclusion of punitive damages than does the text of the statute itself, but which must have meant to exclude punitive damages since it was based on the "return-of-capital" theory, though, inconsistently with that theory, it did not exclude the much more common category of compensation for lost income. Congress supposedly knew all of this, and a reasonably diligent lawyer could figure it out by mistrusting the inclusive language of the statute, consulting the Committee Report, surmising that the Treasury Decision of 1918 underlay that Report, mistrusting the inclusive language of the Treasury Decision, and discerning that Treasury could have overlooked lost-income compensatories, but could not have overlooked punitives. I think not.").

${ }^{350}$ See T.D. 2135,17 Treas. Dec. 39, 42 (1915) (accident insurance policy proceeds and "pain and suffering” recoveries are income); T.D. 2570, 19 Treas. Dec. Int. Rev. 321, 323 (1918)(workers compensation payments are income); T.D. 2690, 20 Treas. Dec. Int. Rev. 130 (1918) ("amount received as
} 
Murphy seems to argue, ${ }^{351}$ early administrative rulings establish the understanding of the enactors of the 16th Amendment, then the administrative rulings issued closer to enactment would be a better guide to the enactor's understandings than later rulings made after the Supreme Court had muddied the waters.

Moreover, following the 1918 Amendments, the Treasury Department interpreted the personal injury exclusion to apply only to physical injuries. ${ }^{352}$ It was only after the Supreme Court's decision in Macomber, discussed below, that the administrators changed their opinion and held that the exclusion applied to non-physical injuries as well. $^{353}$ On its face, the court of appeals' reliance on administrative statutory interpretations made between 1917 to 1922 to establish the understanding in 1913 of the enactors of the 16th Amendment is dubious. But when viewed in their proper historical context - as changes in position brought about by early Supreme Court rulings and Congressional amendments - the court of appeals' argument becomes absurd. In sum, the court of appeals in Murphy cited no proper authority to support its assertion that the enactors of the 16th Amendment intended compensatory human capital recoveries to be outside the reach of Congress's income taxing power.

\section{Constitutionalizing Realization: The Troubled History of Eisner $v$. Macomber and the Meaning of Income.}

The Supreme Court's first interpretation of the word "income" in the 16th Amendment occurred in 1920, with its famous decision in Eisner v. Macomber. ${ }^{354}$ Harking back to the Pollock cases, ${ }^{355}$ Macomber was a 5-4 split decision in which the Court ruled unconstitutional Congress's attempt to tax a pure stock dividend. The issue before the Court in Macomber was very similar to the issue that was decided by the Court four years earlier in Towne $e^{356}$ - whether a dividend of stock in the issuing corporation was income. However, there was one big difference between the two cases. Towne concerned inclusion of a stock dividend under the 1913 Act, which said nothing specific about stock dividends. Macomber, on the other hand, concerned the inclusion of stock dividends under the 1916 Act, which specifically provided that a "stock dividend shall be considered income, to the amount of its cash value."357 Therefore, the justices in Macomber could not avoid the constitutional issue by interpreting the meaning of the statute to exclude stock dividends from income, as they had in Towne.

The Court in Macomber made the decision in Towne constitutional, by concluding that Ms. Macomber's stock dividend did not constitute "income" within the meaning of the 16th Amendment. Therefore under the Pollock Court's definition of direct taxes, which included taxes on personal property, Congress could not tax property - in that case

the result of a suit or compromise for personal injury, being similar to the proceeds of accident insurance, is to be accounted for as income.").

${ }^{351}$ Murphy, 460 F.3d. at 90.

${ }^{352}$ See Sol. Mem. 1384, 1920-2 C.B. 71 (1920) (denying exclusion for recovery of damages for alienation of affection stating 'the term 'personal injuries,' as used therein means physical injuries only.").

${ }^{353}$ Sol. Op. 132, 1-1 C.B. 92 (1922).

${ }^{354} 252$ U.S. 189 (1920).

${ }^{355}$ See discussion supra beginning at note 170

${ }^{356}$ See discussion supra at note 305.

${ }^{357}$ Revenue Act of 1916, 39 Stat. 757, quoted in Macomber, 252 U.S. at 205. 
Ms. Macomber's stock from which there had been no realized income - without apportionment. Justice White, the Pollock dissenter who as Chief Justice wrote the majority opinions in Brushaber and Baltic Mining, was now part of the majority holding the unapportioned tax on a corporate stock dividend to be unconstitutional. ${ }^{358}$

Macomber has no direct application to the Murphy case, because, unlike Ms. Macomber, Ms. Murphy did engage in a transaction resulting in realization when she exchanged her emotional distress damages for cash. However, the Court made a number of important statements in Macomber that could be relevant to the Murphy case.

First, the Court suggested that Congress intended in the 1913 Act to "exert its power to the extent permitted by the [16th] Amendment." "359 This dicta could be interpreted as a reversal of the Court's prior dicta in Towne, in which the Court concluded that the word "incomes" in the 16th Amendment might not be co-extensive with "income" in the 1913 Act. In addition, shortly after Macomber, the Court in Bowers $v$. Kerbaugh-Empire ${ }^{360}$ a case that has been the subject of significant academic criticism, ${ }^{361}$

\footnotetext{
${ }^{358}$ Professor Bruce Ackerman has argued that Justice White's views had changed from the time of his original dissent in Pollock to the time of his majority decisions in Brushaber and Stanton. See Ackerman, supra note 116, at 41. Professor Ackerman argues that Justice White originally sought in his Pollock dissent to continue the Court's historic treatment of direct taxes as applying only to land and capitation. Id. However, by the time to his majority decisions in Brushaber and Stanton, Justice White compromised with the majority to interpret the 16th Amendment only to over-rule Pollock's source rule, and to accept Pollock's theory that a non-income tax on personal property was direct. Id. Professor Ackerman argues that Justice White's later view was incorrect, because the language of the 16th Amendment had been clarified during the initial Congressional debates on the Amendment for the purpose of rejecting Pollock entirely and reinstating the previous limitation of direct taxes to income and capitation. Id. However, Professor Ackerman's theory is debatable. President Taft had proposed a constitutional amendment as a compromise to enacting a new income tax law to force the Court to re-evaluate Pollock. Id. at 35. The Conservatives initially proposed language that would, arguably, have had no effect, since the existing Constitution permitted direct income taxes with apportionment: "The Congress shall have power to lay and collect taxes on incomes and inheritances." See Ackerman, supra note 116 at 36, quoting S.J. Res. 25, 61st Cong., 44 CONG. REC. 1568 (1909). After the liberals pointed out the need to address the apportionment requirement, the conservatives proposed "The Congress shall have power to lay and collect direct taxes on incomes without apportionment among the several States according to population." Ackerman, supra note 116 at 36, quoting 44 CONG. REC. 3377 (1909). This proposal would have implicitly adopted the Pollock definition of direct taxes (which included personal property), rather than the earlier Court view that direct taxes were limited to real estate and capitation taxes. When the liberals suggested instead eliminating the apportionment entirely, for all taxes, the conservatives responded that they were only agreeing to eliminate the apportionment requirement for income taxes. See Ackerman, supra note 116 at 37. A compromise proposed by the Senate Committee on Finance contained the language ultimately adopted. Ackerman, supra note 116 at 38, citing S.J. Res. 40, 61st Cong., 44 ConG. REC. 3900 (1909). Professor Ackerman argues that this compromise shows an intent to return to the pre-Pollock definition of direct taxes - real property and capitation. Ackerman, supra note 116 at 38 . However, the language of the final amendment simply does not address whether non-income taxes on personal property remain subject to the apportionment requirement. It is true, as Professor Ackerman points out, that the language in the initial proposal, which would have validated the Pollock definition, was deleted. But the alternative that was adopted leaves the personal property question open rather than putting it to rest. Contrary to Professor Ackerman's argument, the final language appears to have been a compromise - it neither adopted the Pollock view that taxes on personal property were "direct" nor rejected it.

${ }^{359}$ Eisner v. Macomber, 252 U.S. at 203.

${ }^{360} 271$ U.S. 170 (1926).

${ }^{361}$ See e.g. Deborah H. Schenk, The Story of Kirby Lumber: The Many Faces of Discharge of Indebtedness Income, at 106, REPRINTED IN Tax Stories, supra note 371 ("The whole transaction theory [of KerbaughEmpire] is not only theoretically wrong, it is completely impractical.”). The Court ruled that a taxpayer's
} 
went further in holding that "'Income' has been taken to mean the same thing as used in the Corporation Excise Tax Act of 1909, in the Sixteenth Amendment and in the various revenue acts subsequently passed." 362

Second, the Court adopted the definition of income used in the 1909 Corporate Tax cases: "Income may be defined as the gain derived from capital, from labor, or from both combined,' provided it be understood to include profit gained through a sale or conversion of capital assets, to which it applied in the Doyle case." $" 363$

Third, the Court promoted realization from a matter of statutory convenience to a constitutional mandate by focusing on the word "derived" in the 16th Amendment. According to the Court, "derived" means that the income must be severed from the property in some way. ${ }^{364}$ This notion of severance gave rise to the early concept of realization.

In reaching its conclusion that realization was a constitutional mandate, the Court specifically rejected the government's argument that it could constitutionally tax a shareholder on the income earned by a corporation each year, as it does a partner in a partnership, even if none of that income had been distributed. ${ }^{365}$ The Court, using little in the way of analysis or logic, held that the accrual system that had been allowed by the Court in Collector v. Hubbard ${ }^{366}$ had been overruled by Pollock, and had not been reinstated by the 16 th Amendment. ${ }^{367}$

Four judges dissented from Macomber, in two written dissenting opinions. Justice Holmes, who had written the Court's earlier decision in Towne, wrote a terse dissent arguing that the purpose of the 16th Amendment "was to get rid of nice questions as to what might be a direct tax, and I cannot but doubt that most people not lawyers would suppose when they voted for it they put a question like the present to rest. I am of the opinion that the Amendment justifies the tax." ${ }^{368}$ Justice Brandeis wrote a lengthy Socratic dissent on the merits, arguing both that the 16th Amendment gave Congress the power to tax a shareholder on all corporate earnings, and that the declaration of a stock

gain in U.S. dollars from paying back borrowed German marks at a depreciated value was not taxable because the taxpayer's use of the borrowed funds had resulted in an overall loss. While the Court has never explicitly over-ruled the case on its facts, the theory of the case - focusing on overall results rather than specific transactions within a taxable year - was rejected by the Court in Burnet v. Sanford \& Brooks Company, 282 U.S. 359 (1931).

${ }^{362}$ Id. at 174 .

${ }^{363} I d$. at 193.

${ }^{364}$ Id. ("Here we have the essential matter: not a gain accruing to capital, not a growth or increment of value in the investment; but a gain, a profit, something of exchangeable value proceeding from the property, severed from the capital however invested or employed, and coming in, being "derived," this is received or drawn by the recipient (the taxpayer) for his separate use, benefit and disposal; - that is income derived from property. Nothing else answers the description.") (emphasis in original).

${ }^{365} \mathrm{See} I d$. at 218 ("But this would be a taxation of property because of its ownership, and hence would require apportionment under the provisions of the Constitution, is settled beyond peradventure by previous decisions of this Court.").

${ }^{366} I d$. at 289 .

${ }^{367} I d$. at 219 ("The Government nevertheless insists that the Sixteenth Amendment removed this obstacle, so that now the Hubbard Case is authority for the power to Congress to levy a tax on the stockholder's share of the accumulated profits of the corporation even before division by the declaration of a dividend of any kind. Manifestly, this argument must be rejected, since the Amendment applies to income only, and what is called the stockholder's share in the accumulated profits of the company is capital, not income.").

${ }^{368} I d$. at 220 (Holmes, J., dissenting). 
dividend - which is recognized by the corporation as a distribution of earnings and profits with a consequent mandatory reinvestment in new stock of the corporation - is a proper occasion for recognition of income under a realization system, and had been accepted as such by a number of states. ${ }^{369}$

Legal historians view Macomber as a decision coming at the tail-end of what has become known as the "Lochner Era",370 - a period in which the Court's understanding of judicial review included a power, known as substantive due process, to invalidate what it believed to be improvident social legislation that posed a threat to commercial interests. $^{371}$ Shortly after Macomber, the Court in Evans v. Gore ${ }^{372}$ held that the undiminishable salaries provision of Article III of the Constitution prevented the income tax from reaching the salary of federal judges. In Bailey v. Drexel Furniture Co., ${ }^{373}$ also known as the Child Labor Tax Case, the Court held that Congress could not use its taxing power for the purpose of regulating an activity that it could not regulate directly under its enumerated Constitutional powers. ${ }^{374}$ These decisions were either directly or implicitly repudiated following the flood of new deal social legislation driven by the political winds of the great depression. In O'Malley v. Woodrough, ${ }^{375}$ the Court limited Evans v. Gore to judges appointed prior to enactment of a tax on their income, and in United States $v$. Hatter $^{376}$ finally overruled it. Bailey v. Drexel Furniture Company was never explicitly overruled, but its underlying rationale was rejected when the Court recognized that Congress held a greatly-expanded power of direct regulation under the commerce clause. $^{377}$

\footnotetext{
${ }^{369} I d$. at $226-38$ (Brandeis, J., dissenting).

${ }^{370}$ So-named for Lochner v. New York, 198 U.S. 45 (1905).

${ }^{371}$ See e.g. Marjorie E. Kornhauser, The Story of Macomber: The Continuing Legacy of Realization, at 73, in TAX STORIES, AN IN-DEPTH LOOK AT TEN LEADING FEDERAL INCOME TAX CASES (Foundation Press 2003) ("Macomber is best understood as part of the struggle during the Lochner era to define the nature and scope of government."); Ackerman, supra note 116, at 43 ("To be sure, the year was 1920, and perhaps Justice Pitney thought that the "function" of the clause went without saying in an era dominated by the laissez-faire presuppositions of Lochner v. New York.").

372253 U.S. 245 (1920).

${ }^{373} 259$ U.S. 20, 37-38 (1922).

${ }^{374}$ The Court in Hammer v. Dagenhart, 247 U.S. 251 (1918), had held that Congress could not prohibit the use of child labor under its power to regulate interstate Commerce. In response, in 1919, Congress imposed a special tax in the amount of $10 \%$ of net profits on anyone using defined child labor. Title XII of the Revenue Act of February 24, 1919, c. 18, 40 Stat. 1138 (1919). The Court in Bailey held the 1919 tax unconstitutional as an improper disguised attempt to regulate intrastate commerce.

375307 U.S. 277 (1939).

376532 U.S. 557 (2001) ("There is no good reason why a judge should not share the tax burdens borne by all citizens. Although Congress cannot directly reduce judicial salaries even as part of an equitable effort to reduce all Government salaries, a tax law, unlike a law mandating a salary reduction, affects compensation indirectly, not directly.).

${ }^{377}$ Hammer v. Dagenhart, 247 U.S. 251 (1918), the decision preventing Congress from directly regulating child labor, was over-ruled in United States v. Darby, 312 U.S. 100 (1941). Thus, the theory underlying the Court's decision in Bailey - that Congress could not regulate child labor by directed taxation since it could not regulate child labor directly - was entirely undercut. In Rockefeller v. United States, 572 F. Supp. 9, 13 (E.D. Ark. 1982), the district court suggested that the general theory of Bailey - that Congress could not regulate with a tax that which it could not regulate directly - was effectively overruled by the Court's later decisions, such as United States v. Sanchez, 340 U.S. 42, $44-45$ (1950), in which the Court stated: "It is beyond serious question that a tax does not cease to be valid merely because it regulates, discourages, or definitely deters the activity taxed. The principle applies even though the revenue obtained is obviously
} 
However, Macomber has never been overruled. Professor Ackerman expressed some surprise that the split decision in Macomber was met with "a long period of judicial silence extending from the 1920s through today" rather than, as one would expect of a such a famous divided decision "judicial debate and reappraisal." silence can be explained by the Court's quick narrow interpretation of the holding, and subsequent retreat from the definitions used by the Court in Macomber.

The narrow interpretation began the following year in Merchants' Loan \& Trust Co. v. Smietanka. ${ }^{379}$ Emboldened by Macomber, some loose dicta in Turrish, ${ }^{380}$ and a misunderstanding of the difference between the accrual income tax system utilized during the Civil War as interpreted in Gray v. Darlington and the realization system utilized by the 20th Century taxing statutes, ${ }^{381}$ taxpayers challenged the ability of the government to tax isolated realized gains from the sale of capital assets. This was nothing short of an attempt to eviscerate the 16th Amendment by limiting Congress's power to tax income to essentially that which had already been recognized under the 1909 Corporate Income Tax Act - taxes on business activities but not on isolated property activities. The challengers were emboldened when, shortly after Macomber, a district court in Connecticut held that Congress could not constitutionally tax the increase in value of property (bonds, in that case) upon sale because the increase was not "income" within the meaning of the 16th Amendment. ${ }^{382}$ A note in the Harvard Law Review criticized the district court's ruling for turning a statutory interpretation issue into a constitutional one, and criticized Eisner v. Macomber for ignoring the popular mandate by restricting the power of Congress to legislate. ${ }^{383}$ Nevertheless, a concerned Congress enacted special non-recognition rules to defer the taxation of gains realized on like kind exchanges. ${ }^{384}$ The concern about capital gains was short-lived, however. Only one year after Macomber, the Court in Smietanka firmly rejected the notion that realized gains on capital assets could not be taxed. ${ }^{385}$

Smietanka was quickly followed by United States v. Phellis, ${ }^{386}$ a case involving the reorganization of the Du Pont company. Before the reorganization, the taxpayer in Phellis held stock in a New Jersey Du Pont Corporation. The New Jersey Du Pont reorganized by transferring its business assets to a new Delaware Du Pont corporation in return for the Delaware corporation's stock. The New Jersey Du Pont then distributed some of its stock in the Delaware Du Pont to the taxpayer. The New Jersey Du Pont

neglible, or the revenue purpose of tax may be secondary. Nor does a tax statute necessarily fall because it touches on activities which Congress may not otherwise regulate."

${ }^{378}$ Ackerman, supra note 116 , at 46.

${ }^{379} 255$ U.S. 509 (1921).

${ }^{380}$ Lynch v. Turrish, 247 U.S. at 230 (interpreting Gray v. Darlington as holding "that such advance in value is not income at all, but merely increase of capital and not subject to a tax as income.").

${ }^{381}$ See discussion supra beginning at note 292.

${ }^{382}$ Brewster v. Walsh, 268 Fed. 207 (Conn 1920), rev'd in part 255 U.S. 536 (1921).

${ }^{383}$ Note, 34 HARV. L. REV. 536 (1921).

${ }^{384}$ Revenue Act of 1921, ch. 136, 42 Stat. 227 (1921).

${ }^{385}$ Smietanka, 255 U.S. at 519-20 ("Since the fund here taxed was the amount realized from the sale of the stock in 1917, less the capital investment as determined by the trustee as of March 1, 1913, it is palpable that it was a 'gain or profit' 'produced by' or 'derived from' that investment, and that it 'proceeded,' and was 'severed' or rendered severable, from it, by the sale for cash, and thereby became that 'realized gain' which has been repeatedly declared to be taxable income within the meaning of the constitutional amendment and the acts of Congress.").

${ }^{386} 257$ U.S. 156 (1921). 
stayed in business as a holding company. After the reorganization, the combined Delaware and New Jersey Du Pont's had the same assets, and were owned and run by the same people, as was the New Jersey corporation before the reorganization. The trial court even noted that the market value of the taxpayer's investment before and after the reorganization had not changed. Nevertheless, the Supreme Court, noting that equivalency in market value is irrelevant, held that the stock dividend was taxable. The proper question was whether the essential nature of the taxpayer's investment had changed in any material respect. The Court distinguished Macomber, holding that Du Pont's dividend of stock in the new corporation was taxable because the fundamental nature of the taxpayer's investment had been changed in several ways: the new Delaware corporation was incorporated in a different state with different governance rules, was authorized to issue a much larger amount of capital stock than the old corporation, and was legally separate from the old corporation which continued in existence. ${ }^{387}$ Phellis, and other similar cases that followed, ${ }^{388}$ thus limited Macomber to a very clean stock dividend.

Furthermore, each of the principles announced in Macomber have gone through substantial revision or have been outright rejected by later courts. The idea that the word "income" had in the 16th Amendment the same meaning as it was interpreted to have in the first taxing acts has been greatly limited. Eleven years after Macomber, the Court in Burnet v. Sanford \& Brooks Company ${ }^{389}$ recognized that there are many possible systems of income taxation, and that it was Congress in enacting the taxing statutes, and not the 16th Amendment, that decided which of the permissible systems to adopt. ${ }^{390}$ While the courts have continued to say that Congress intended to exercise its full taxing power in IRC section $61,{ }^{391}$ the statement is properly tempered by the practical realities of the realization system chosen by Congress, the specific statutory exclusions enacted by

${ }^{387} \mathrm{Id}$. at 172-73 ("In the light of all this we cannot regard the new company as virtually identical with the old, but must treat it as a substantial corporate body with its own separate identity, and its stockholders as having property rights and interests materially different from those incident to ownership of stock in the old company.").

${ }^{388}$ Rockefeller v. United States, 257 U.S. 176 (1921); Cullinan v. Walker, 262 U.S. 134 (1923); Weiss v. Stearn, 265 U.S. 242 (1924); Marr v. United States, 268 U.S. 536 (1925); Koshland v. Helvering, 298 U.S. 441 (1936).

389282 U.S. 359 (1931).

${ }^{390} \mathrm{Id}$. at 365 ("The computation of income annually as the net result of all transactions within the year was a familiar practice, and taxes upon income so arrived at were not unknown, before the Sixteenth Amendment. It is not to be supposed that the amendment did not contemplate that Congress might make income so ascertained the basis of a scheme of taxation such as had been in actual operation within the United States before its adoption. While, conceivably, a different system might be devised by which the tax could be assessed, wholly or in part, on the basis of the finally ascertained results of particular transactions,

Congress is not required by the amendment to adopt such a system in preference to the more familiar method, even if it were practicable.") (citations omitted, emphasis added).

${ }^{391}$ See e.g. United States v. Burke, 504 U.S. 229, 233 (1992) ("As this Court has recognized, Congress intended through $\S 61$ (a) and its statutory precursors to exert 'the full measure of its taxing power,' and to bring within the definition of income any 'accession to wealth."') (citations omitted); Commissioner v. Glenshaw Glass Co., 348 U.S. 426, 429 (1955) ("This Court has frequently stated that this language was used by Congress to exert in this field "the full measure of its taxing power.") (citations omitted); Helvering v. Clifford, 309 U.S. 331, 334 (1940) ("The broad sweep of this language indicates the purpose of Congress to use the full measure of its taxing power within those definable categories."). 
Congress, ${ }^{392}$ and by the historical exclusions that have been recognized by the Treasury Department in the administration of the tax laws either for reasons of administrative convenience or fundamental fairness.

Similarly, by 1940, the Court had pulled away from the notion that realization was mandated by the 16th Amendment. The pullback began in Helvering v. Braun. ${ }^{393}$ Prior to Braun, the courts had relied on Macomber in holding that a tenant's improvements to the landlord's property were not income to the landlord at the time the improvements were made, nor were ratable portions of the value of the tenant's improvements additional rent that could be taxed over the term of the lease. ${ }^{394}$ The landlord in Braun argued that the improvements could not be taxed until the property was sold, and any gain "severed" from the real estate. The Court rejected the landlord's argument, allowing the value of the improvements to be taxed to the landlord at the time the lease terminated. Braun was decided on the basis of the broad language used in the taxing statute, which the Court said "follows closely the Sixteenth Amendment." ${ }^{395}$ Later that year, in Helvering v. Horst ${ }^{396}$ the Court held that a donor would be taxed on the interest paid on a bond even though the interest coupon had been given to the donor's son before it matured and was paid. The Court held that the gift of the income coupon was a realization event. In defining realization, the Court backed far away from the constitutional mandate it had found in Macomber:

From the beginning the revenue laws have been interpreted as defining "realization" of income as the taxable event, rather than the acquisition of the right to receive it. ... The rule [that income is not taxable until realized], founded on administrative convenience, is only one of postponement of the tax to the final event of enjoyment of the income, usually the receipt of it by the taxpayer, and not one of exemption from taxation where the enjoyment is consummated by some event other than the taxpayer's personal receipt of money or property. ${ }^{397}$

More recently, the Court in Cottage Savings Association v. Commissioner, ${ }^{398}$ reaffirmed the notion that realization is merely a matter of administrative convenience, ${ }^{399}$ and that Macomber remains of interest only because Congress enacted its statutory rules in that "contemporary legal context."

\footnotetext{
${ }^{392}$ See IRC $\S \S 101-140$ (items specifically excluded from Gross Income).

393309 U.S. 461 (1940).

${ }^{394}$ Hewitt Realty Co. v. Commissioner, 76 F.2d 880 (2nd Cir. 1935) (improvements not taxable to landlord when improvements made); M. E. Blatt Co. v. United States, 305 U.S. 267 (1938) (improvements not taxable as rent over life of lease).

${ }^{395} 309$ U.S. at 468 . This was a significant change from prior language suggesting that "income" has the same meaning under both the statute and the Amendment. See discussion supra at notes 359 to 362 .

${ }^{396} 311$ U.S. 112 (1940).

${ }^{397} \mathrm{Id}$. at 115-16 (emphasis added).

398499 U.S. 554 (1991).

${ }^{399} \mathrm{Id}$. at 559 ("As this Court has recognized, the concept of realization is 'founded on administrative convenience.' Helvering v. Horst, 311 U.S. 112, 116 (1940).").

${ }^{400}$ Cottage Savings, 318 U.S. at 562 ("Because these decisions [including Macomber] were part of the "contemporary legal context" in which Congress enacted [the statute in issue] . .., and because Congress
} 
Finally, the Court has rejected Macomber's narrow definition of income, which was taken from the 1907 Corporate Tax - "a gain derived from capital, labor or both combined." 401 In deciding that windfall recoveries like punitive damages were taxable as income, the Court in Commissioner v. Glanshaw Glass ${ }^{402}$ defined income broadly to include all "undeniable accessions to wealth, clearly realized, and over which the taxpayers have complete dominion," 403 and held that the definition used in Macomber "was not meant to provide a touchstone to all future gross income questions.",404

Although virtually every aspect of the Macomber holding has been undermined, the Court has never over-ruled the case, and in fact specifically declined an invitation to do so. The opportunity to reconsider Macomber arose when Congress amended the statute to provide for the taxation of all stock dividends unless they do "not constitute income to the shareholder within the meaning of the Sixteenth Amendment to the Constitution." ${ }^{405}$ The statute was first amended in 1936, but the issue did not come before the Supreme Court until the 1943 case of Helvering v. Griffiths. ${ }^{406}$ In Griffiths, the government asked the Court to finally over-rule Macomber by holding that the small stock dividend in issue would be taxable under the 1939 Code. While recognizing that the "original theoretical bases of the decision in Eisner v. Macomber" had been undermined by later decisions of the Court, the Court nevertheless declined to over-rule Macomber, finding instead that Congress, in enacting the new statutory language, had intended to incorporate rather than challenge the rule of Macomber. ${ }^{407}$ In his dissent in Griffiths, Justice Douglas said that "Eisner v. Macomber dies a slow death.",408

Indeed it does, for the court of appeals' decision in Murphy transports us back nearly 90 years to a time when courts thought they were empowered to overturn the taxing acts of Congress by attributing to the language of the 16th Amendment a meaning that they desire - a meaning nowhere expressed in the statute or its history. The only clear purpose of the 16th Amendment was to overturn the Pollock Court's interpretation of the direct taxing clause as a restriction on Congress's power to impose broad based taxes on income from property without apportionment. Congress may well have thought it necessary or advisable in 1918 to exclude personal injury awards after the Supreme Court had narrowly interpreted income as a "gain from capital, from labor or from both combined," but it is difficult to see how that ruling should have currency today, under the much broader definition of income adopted by the Supreme Court in Glenshaw Glass. ${ }^{409}$

By attributing constitutional currency to statutory decisions from the Macomber era, the court of appeals in Murphy unwittingly returned to a long-ago rejected definition of "income." Under the standard enunciated by the Court in Glenshaw Glass, the proper

has left undisturbed through subsequent reenactments of the Code the principles of realization established in these cases, we may presume that Congress intended to codify these principles in $\S 1001(\mathrm{a})$.").

${ }^{401}$ See discussion supra at note 363.

402348 U.S. 426 (1955)

${ }^{403} \mathrm{Id}$. at 431 .

${ }^{404} \mathrm{Id}$.

${ }^{405}$ Internal Revenue Code of 1939, Pub. L. No. 1, 53 Stat. 1, § 115(f) (1939).

406318 U.S. 371 (1943).

${ }^{407} \mathrm{Id}$. at 404 ("We are unable to find that Congress intended to tax the dividends in question, and without Congressional authority we are powerless to do so. That being the case, we cannot reach the reconsideration of Eisner v. Macomber on the basis of the present legislation and Regulations.").

${ }^{408} \mathrm{Id}$. at 404 (Douglas, J. dissenting).

${ }^{409}$ Commissioner v. Glenshaw Glass, 328 U.S. 426 (1955), discussed supra note 402. 
question in Murphy was whether Ms. Murphy realized an "accession to wealth" when she exchanged her emotional distress damages for cash, not whether Ms. Murphy realized a gain from her capital or labor. To determine whether Ms. Murphy realized an "accession to wealth," it is necessary to determine what the Supreme Court means by wealth. If, as the court of appeals in Murphy seemed to suggest, wealth means the fair market value of one's property at the time of sale, than virtually no arms' length sale would result in an accession of wealth. On the other hand, if wealth consists solely of previously taxed or previously exempted income that has been invested in real or personal property, under the concept called "basis," then Ms. Murphy's entire award would constitute an "accession to wealth" and be income.

\section{(4) Ms. Murphy Realized Income Because She Had No Basis in Her Human Capital.}

The court of appeals in Murphy held that Ms. Murphy's award of emotional and reputational damages was not "income" because it was intended to compensate Ms. Murphy for her lost emotional well being, and that emotional well being would not have been subject to tax if it had not been lost. ${ }^{410}$

There are two conceptual problems with the court of appeals' holding. First, it is not necessarily true that Ms. Murphy would not have received additional taxable income if her emotional well being had not been lost. In order to recover lost wages, a claimant must generally prove precise and specific losses. ${ }^{411}$ While Ms. Murphy did not receive a separate award for lost wages (presumably because she could not prove specific wage losses), it is entirely possible that she would have made more income from her labor if she had been feeling well than she made in her impaired state. An inability to prove the precise amount of losses does not mean losses did not occur. Whether Ms. Murphy's emotional well being would have been consumed in leisure or used to generate additional income is entirely speculative. Indeed, the proponents of the amendment to IRC section 104(a)(2) stated in the House committee report the belief that emotional distress claims generally result in receipts that would have generated taxable income if the emotional distress had not occurred. ${ }^{412}$ Certainly it would be difficult for the administrators of the tax law and the courts to determine precisely how much of a general compensatory award compensated for losses that would have resulted in additional taxable income if the losses had not occurred and how much of the award compensated for the loss of one's own

${ }^{410}$ Murphy, 460 F.3d at 92 ("Murphy's compensatory award in particular was not received 'in lieu of' something normally taxed as income.").

${ }^{411}$ See e.g. MATTHEW BENDER, DAMAGES IN TORT ACTIONS $\S 3.04,121.20$ (2006) (party claiming damages for lost earnings or profits, or future damages for loss of earning capacity, must prove the fact and amount of damages with "reasonable certainty." Fact and amount of damages cannot be based on speculation or conjecture); Quiktrip Corp. v. Childs, 220 Ga. App. 463, 469 S.E.2d 763 (1996) (plaintiff established lost earnings with "reasonable certainty" by introducing into evidence prior three years" tax returns); Colezetti v. Pircio, 214 A.D.2d 926, 625 N.Y.S.2d 726 (1995) (general assertions that injuries caused plaintiff to miss time from work, to fail to complete jobs timely and to lose consulting jobs does not satisfy requirement of "reasonable certainty").

${ }^{412}$ See House Committee Report on Small Business Job Protection Act of 1996, H. REPT. No. 104-586 at 143 (1996), 1996-3 C.B. 331, 481 ("Damages received on a claim not involving physical injury or physical sickness are generally to compensate the claimant for lost profits or lost wages that would otherwise be included in taxable income.”). 
consumption of human capital (which would not have been subject to taxation). The court of appeals' counter-factual conclusion that the lost emotional well being would not have resulted in additional taxable income was both speculative and contrary to Congress's purpose in restricting the exclusion in IRC section 104(a)(2).

Secondly, in determining that Ms. Murphy realized no gain or accession to wealth as a result of the emotional and reputational damages award, the court of appeals incorrectly focused on the market value of the property rights (Ms. Murphy's lost human capital as a result of her injury) that were exchanged for cash in the award, rather than Ms. Murphy's tax cost basis in the property exchanged (her lost human capital).

From the time of the first modern income tax acts, Congress and the courts recognized that not all gross proceeds from the sale of property constitute income under the taxing acts. ${ }^{413}$ Some sales proceeds represented merely the recovery of the taxpayer's original investment. As a general matter, the funds used to make that original investment in the property had come either from income that had been previously taxed, from income that had been permanently exempted from tax when earned (either because the funds had been earned before the income tax law went into effect, or because the funds were for some other reason not subject to tax), or from borrowed funds that would have to be repaid from previously taxed income. ${ }^{414}$ For example, when a taxpayer buys property for $\$ 100$, and later sells the property for $\$ 300$. We all know that the taxpayer has $\$ 200$ of gain that is realized as income at the time of sale. The income tax statute does not reach the entire $\$ 300$ in sale proceeds because $\$ 100$ of the proceeds represents merely the recovery of taxpayer's original cost in purchasing the property. To tax the original taxpayer again at the time of sale on the recovery of the taxpayer's original investment of $\$ 100$ would either be to impose a double tax on the same original income earned by the same taxpayer, or to tax previously exempted income that had been invested in property.

The IRC keeps track of the taxpayer's investment in property of previously taxed or exempt income through a mechanism called "basis." The taxpayer receives basis for the original purchase cost of the property, ${ }^{415}$ and gets an increase in basis for any

\footnotetext{
${ }^{413}$ Prior to the adoption of the 16th Amendment, the Supreme Court had defined income from property as the increase in value during ownership. See Gray v. Darlington, 82 U.S. 63 (1872) (gain in value of bonds); Stratton's Independence, Ltd. v. Howbert, 231 U.S. 399 (1913) (gains from operation of mine). While the early Courts did not discuss the notion of cost basis, the principle that the recovery of the taxpayer's previously taxed capital would not be income was well recognized. The 1913 Act imposed a tax on "net income" which included "the gains, profits and income derived from ... sales or dealings in property, whether real or personal, growing out of the ownership or use of or interest in real or personal property." Tariff Act of October 3, 1913, § II, ch. 16, 38 Stat. 166, 167. The 1916 Act used the same language, but added an exclusion for the value of the property on March 1, 1913, if acquired before that date. Revenue Act of 1916, ch. 463, 39 Stat. 756. While these early tax statutes did not more specifically define the word "gain," it was recognized that the mere recoupment of an original investment did not represent gain.

${ }^{414}$ Even if the $\$ 100$ came from borrowed funds rather than income, those funds will either have to be repaid with previously taxed or excluded income, or, if the debt is canceled, cancellation of indebtedness income will have to be recognized. See United States v. Kirby Lumber Co., 284 U.S. 1 (1931); IRC $\S 108(a)$. The tax system gives the taxpayer a basis in borrowed funds because of the taxpayer's obligation to repay the loan.

${ }^{415}$ IRC $\S 1012$.
} 
additional non-deductible capital improvement investments made in the property. ${ }^{416}$ Likewise, the taxpayer must reduce basis for the benefits received from the property, either in the form of tax deductions for depreciation and the like or other non-taxable recoveries received from the property. ${ }^{417}$ The cost basis, as adjusted up for additional investments and down for the recovery of benefits, is known as the "adjusted basis." When the property is sold, the tax cost "adjusted basis," representing the taxpayers investment of already-taxed or exempt income in the property, is subtracted from the sales price (known as the "amount realized") in arriving at the gain that is subject to tax. $^{419}$ The fundamental purpose of these basis rules is to prevent a taxpayer from being taxed twice on the same income, or from being taxed on income earned earlier that had been exempted. The untaxed increase in the value of property prior to realization may constitute economic capital or wealth, but, because that increase in value was not previously subject to tax and was not permanently exempted, it does not result in basis that can be used to offset gain. This concept of basis is necessary for a realization system of income taxation to properly reach, at the time of realization, the increase in the value of property that accrued in prior periods.

The distinction between a recovery of economic capital and a recovery of tax-cost basis was recognized in by the Court of Appeals for the First Circuit in Raytheon Production Corp. v. Commissioner. ${ }^{420}$ The issue in Raytheon was whether a corporation was required to include in income an anti-trust damages recovery. The court of appeals first recognized that anti-trust damages recovered on account of lost profits would be taxable because the lost profits would have been taxable. The development of the "in lieu of what" test for allocating recoveries is often credited to the opinion in Raytheon.

Equally important were the Raytheon court's comments about the distinction between basis and economic capital. After holding that Raytheon's anti-trust recoveries were on account of good will (generally not taxed until the business is sold) and not lost profits (generally taxed each year), the court considered whether the recoveries of capital might nevertheless be subject to taxation as income. The court of appeals rejected Raytheon's argument that capital recoveries were inherently non-taxable:

[T]o say that the recovery represents a return of capital in that it takes the place of the business good will is not to conclude that it may not contain a taxable benefit. Although the injured party may not be deriving a profit as a result of the damage suit itself, the conversion thereby of his property into cash is a realization of any gain made over the cost or other basis of the good will prior to the illegal interference. Thus A buys Blackacre for $\$ 5,000$. It appreciates in value to $\$ 50,000$. B tortiously destroys it by fire. A sues and recovers $\$ 50,000$ tort damages from $B$. Although no gain was derived by $\mathrm{A}$ from the suit, his prior gain due to the

\footnotetext{
${ }^{416}$ IRC $\S 1016$ (a) (basis increased for "expenditures . . . or other items properly chargeable to capital account.")..

${ }^{417}$ IRC $\$ 1016(\mathrm{a})(2)$.

${ }^{418}$ IRC $\S 1011(a)$.

${ }^{419}$ See IRC $\S 1001$.

${ }^{420} 144$ F.2d 110 (1st Cir. 1944).
} 
appreciation in value of Blackacre is realized when it is turned into cash by the money damages. Compensation for the loss of Raytheon's good will in excess of its cost is gross income. ${ }^{421}$

This distinction between a taxable recovery of capital and a non-taxable recovery of basis is fundamental to the realization system of income taxation utilized since the adoption of the 16 th Amendment. ${ }^{422}$

After first focusing on ancient understandings of the word "income" from the early 20th Century, the court of appeals in Murphy correctly framed the issue before it in the modern terms employed in Glenshaw Glass - whether Ms. Murphy's compensatory damage award resulted in an accession to wealth ${ }^{423}$ - but then failed to analyze the question in a coherent way. The court of appeals simply concluded that Ms. Murphy's award was "but a restoration of the status quo ante, analogous to a restoration of capital, in neither context does the payment result in a 'gain' or 'accession to wealth.",424

The court of appeals in Murphy ruled that emotional distress damages awards are not taxable because they compensate for something that would not have been taxed if it had not been lost - emotional and reputational well-being that would not have resulted in additional wages. The court of appeals suggested that Ms. Murphy received no gain - no "accession to wealth" - because the value of her lost emotional and reputational wellbeing equaled the amount of the settlement. ${ }^{425}$ But gain is not measured by the value at the time of exchange of the property interests transferred. As we have seen, gain $^{426}$ in property transactions is measured by deducting from the amount realized in the exchange only the seller's tax-cost basis in the property. ${ }^{427}$ In computing gain, the seller cannot reduce the amount realized by the market value of the property sold. Under the court of appeals' analysis in Murphy, an arm's length sale of property would generally result in no taxable income, because the amount received from the sale would simply equal the value of the property transferred - and thus there would be no gain. The court of appeals' approach ignores the appreciation in value that is inherent in the property sold. That appreciation is realized as taxable gain at the time of sale.

The court of appeals rejected the government's argument that Ms. Murphy did not have any basis in her human capital, and therefore the entire amount received from the settlement was gain or income. ${ }^{428}$ The court of appeals simply said "we reject the

${ }^{421} I d$. at 114 .

${ }^{422}$ See discussion of Towne v. Eisner, 245 U.S. 418 (1918), supra note 305.

${ }^{423}$ Murphy, 460 F.3d. at 85.

${ }^{424}$ Murphy, 460 F.3d. at $88 \mathrm{n}$. (citations omitted).

${ }^{425}$ See supra note 424 (contending that Ms. Murphy had no income because the value of the human capital she lost and money she received were equal, without considering whether she had any tax cost basis in her human capital).

${ }^{426}$ IRC $\$ 1001(a)$.

${ }^{427}$ IRC $§ 1011$.

${ }^{428}$ Murphy, 460 F.3d. at 87 (“[T]he Government challenges the coherence of Murphy's analogy between a return of "human capital or well-being' and a return of "financial capital," . . The Government first observes that financial capital, like all property, has a "basis," . . The Government then observes that '[b]ecause people do not pay cash or its equivalent to acquire their well-being, they have no basis in it for purposes of measuring gain (or loss) upon the realization of compensatory damages.' ... At the outset, we reject the Government's breathtakingly expansive claim of congressional power under the Sixteenth Amendment.”). 
Government's breathtakingly expansive claim of congressional power under the Sixteenth Amendment - upon which it founds the more far-reaching arguments advanced here." $" 429$

Yet, the point made by the government is fundamental. The court of appeals in Murphy erred by focusing on whether Ms. Murphy recovered capital, rather than focusing on whether Ms. Murphy recovered more than her tax-cost basis. Any recovery in excess of basis causes an increase in realized wealth, and the Supreme Court has made it clear that increases in realized wealth are income. ${ }^{430}$ If human capital recoveries were taxed as property, then the court of appeals in Murphy should have taxed the amount of the award that exceeded Ms. Murphy's proven basis in her human capital.

By focusing solely on whether the recovery constitutes a return of capital, without regard to tax-cost basis, the court of appeals in Murphy charts a return to the days before Smietakna ${ }^{431}$ when some thought that capital gains could not be taxed as income because there had been no gain - measured by the value of the market value of the property transferred at the time of the exchange. The court of appeals in Murphy failed to consider whether Ms. Murphy's tax-basis wealth was increased when she received a cash payment on account of a human capital interest that had not been previously taxed or permanently exempted from tax when it accrued. ${ }^{432}$

Other courts have recognized that a taxpayer must recognize income upon the sale of human capital. For example, in Roemer v. Commissioner, ${ }^{433}$ the Court of Appeals for the Ninth Circuit allowed the taxpayer to exclude damages recovered for defamation under an earlier version of IRC section 104(a)(2). In a footnote, however, the court noted:

Since there is no tax basis in a person's health and other personal interest, money received as compensation for an injury to those interests might be considered a realized accession to wealth. Nevertheless, Congress in its compassion has retained the exclusion. $^{434}$

In Polone v. Commissioner, ${ }^{435}$ the taxpayer settled a defamation claim prior to the effective date of the 1996 amendments adding the "physical injury or physical sickness" to section 104(a)(2). However, the settlement provided for structured payments to be made in the future, which were held to be subject to the new statute when received. The Ninth Circuit held that the payments were taxable as income because the taxpayer had no

\footnotetext{
${ }^{429} \mathrm{Id}$.

${ }^{430}$ See discussion of Smietanka, supra beginning at note 379

${ }^{431}$ See discussion supra beginning at note 379.

${ }^{432}$ Human capital is not permanently exempted from taxation because, when labor is sold, the wages are taxable. It is only human capital that is consumed by the taxpayer in the form of leisure that results in no taxable income. If, rather than being consumed, human capital is sold for money that can be used to satisfy other desires, it is subject to tax. See discussion infra part IV.B(5) beginning on page 71 .

433716 F.2d 693 (9th Cir. 1983).

${ }^{434}$ Id. at 696 n. 2.

435449 F.3d 1041 (9th Cir. 2006).
} 
basis in his human capital. ${ }^{436}$ Cases involving the sale of one's blood recognize that the proceeds received are income because a taxpayer has no basis in their own body parts. ${ }^{437}$

The court of appeals' holding that Ms. Murphy's emotional and reputational damages award was not income was thus wrong for two reasons. First, the court of appeals erred in concluding that the award was not received in lieu of income that would have been taxed, because Ms. Murphy's emotional and reputational losses may well have reduced her taxable income from what it would have been if the losses had not occurred. Second, even if it were proper to treat human capital as property, an issue discussed below, ${ }^{438}$ the court of appeals failed to recognize that Ms. Murphy's award resulted in an accession to her tax-basis wealth, because she had not previously been taxed on the increase in the value of her lost human capital.

This basis analysis assumes that human capital would be treated like financial capital by the income tax system. As discussed below, the implicit theory underlying the court of appeals' holding in Murphy would work a substantial change in the taxation of income from human capital, and would threaten the longstanding treatment of wages as taxable income.

\section{Ms. Murphy's Receipts from Human Capital Were Income.}

The court of appeals in Murphy erred by assuming that human capital is wealth, and thus that Ms. Murphy realized no accession to wealth, and thus no income, when she received the award of emotional and reputational damages.

The modern concept of human capital was largely developed by economists beginning in the 1950s. ${ }^{439}$ According to economist Gary Becker's Nobel Prize speech, which was cited by the court of appeals in Murphy as support for Ms. Murphy's argument that her damages award was a recovery of capital rather than income, ${ }^{440}$ the modern concept of human capital is based on the theory that "individuals decide on their education, training, medical care, and other additions to knowledge and health by weighing the benefits and costs. Benefits include cultural and other non-monetary gains along with improvement in earnings and occupations, while costs usually depend mainly

\footnotetext{
${ }^{436} \mathrm{Id}$. at 1045 (““"Polone's defamation claim has no adjusted basis within the meaning of $\S 1001 \ldots$ [A]djusted basis" would have had to have been calculated pursuant to $\S 1012$. A $\S 1012$ calculation, however, is based on cost, which is antithetical to a defamation claim. . . Such a personal injury cannot reasonably be said to have a cost in the traditional market sense that $\S 1012$ requires, in that one cannot sell one's dignity as a commodity on the open market. . . . Because Polone's defamation claim had no adjusted basis and was not transferable under California law, his settlement with UTA could not have been a "sale or other disposition of property" for purposes of $\S 1001 . ")$.

${ }^{437}$ See Lary v. United States, 787 F.2d 1538,1540-41 (11th Cir. 1986) (because taxpayer has no basis in own blood, no charitable deduction allowed for donation); Green v. Commissioner, 74 T.C. 1229,1233-34 (1980) (regular sale of blood constitutes business for which expenses attributable to business are deductible).

438 See infra Part IV.B(5) beginning on page 71.

439 See Gary S. Becker, The Economic Way of Looking at Life, Lecture to the Memory of Alfred Nobel, p. 43 (December 9, 1992), available at http://nobelprize.org/nobel prizes/economics/laureates/1992/beckerlecture.html ("Until the 1950s economists generally assumed that labor power was given and not augmentable. .. . Human capital is so uncontroversial nowadays that it may be difficult to appreciate the hostility in the 1950s and 1960s toward the approach that went with the term.").

${ }^{440}$ Murphy, 460 F.3d at 85.
} 
on the foregone value of the time spent on these investments." $" 441$ The court of appeals did not explain why these modern economic theories of human behavior should dictate tax policy, or more importantly how these recent theories support the court of appeals' view that the enactors of the 16th Amendment in 1913 thought that human capital recoveries were not income.

Modern economic theories aside, the history of wage taxation shows that human capital has never been treated as property. Wages under every income tax act have been taxable as income without reduction for one's basis in the human capital being sold. It could have been otherwise. The tax system could have been structured to require taxpayers to keep track of their investments in human capital - everything from education and non-deductible medical expenditures, to food, shelter and clothing - and to reduce the gains realized from the sale of human capital in the form of wages or damages settlements by the amount of those investments. However, the tax system has never treated human capital as property. Unless specifically allowed by statute, investments in one's own human capital do not give rise to basis that can be used to offset amounts realized from the sale of human capital for wages or other fees. ${ }^{442}$

In fact, all proceeds from the sale of human capital have been taxed as income, unless Congress has saw fit to provide an exemption or a deduction. Congress has always taxed the gross proceeds from the sale of labor, and arguments that wages should be treated as a non-taxable recovery of capital have been repeatedly rejected as frivolous by the Supreme Court and the courts of appeals in every circuit. ${ }^{443}$ Therefore, the notion that payments on account of human capital are not income because they are in lieu of human capital, which would not be taxed if consumed through leisure rather than sold, is simply incorrect.

\footnotetext{
${ }^{441} I d$.

${ }^{442}$ See IRC $\S \S 61(a)(1)$ (taxing all compensation for services); 1012, 1011 (authorizing basis for "property"). See also e.g. IRC $\S 262$ (no deduction for personal family or household expenses); Treas. Reg. § 1.162-5(b)(1) (disallowing deduction for educational training to enter new profession because costs "constitute an inseparable aggregate of personal and capital expenditures."); Sharon v. Commissioner, 66 T.C. 515 (1976), aff'd 591 F.2d 1273 (1978) ("Since the inseparable aggregate includes personal expenditures, the preeminence of section 262 over section 167 precludes any amortization deduction [for educational expenses].").

${ }^{443}$ See e.g. Cheek v. United States, 498 U.S. 192 (1991) (discussing when long-rejected tax protestor arguments, such as erroneous belief that wages are not income, could be valid defense to criminal charge of tax evasion); United States v. Simkanin, 420 F.3d 397 (5th Cir. 2005) (upholding conviction); United States v. Melton, 1996 U.S. App. LEXIS 11683, 77 A.F.T.R.2d (RIA) 2361 (4th Cir. 1996) (same); United States v. Bonneau, 970 F.2d 929 (1st Cir. 1992) (upholding criminal conviction of taxpayer asserting wages not income because recovery of human capital); United States v. Capps, 1991 U.S. App. LEXIS 10669 (10th Cir. 1991); United States v. Connor, 898 F.2d 942, 943-44 (3rd. Cir. 1990), cert. den. 497 U.S. 1029 (1990) ("We take this opportunity to reiterate that wages are income within the meaning of the Sixteenth Amendment."); Coleman v. Commissioner, 791 F.2d 68, 70 (7th Cir. 1986) (Taxpayer Coleman argued that "personal depreciation offsets the wage, leaving no net income. ... These are tired arguments."); Biermann v. Commissioner, 769 F.2d 707, 708 (11th Cir. 1985); Connor v. Commissioner, 770 F.2d 17, 20 (2d Cir. 1985) ("Wages are income. The argument that they are not has been rejected so frequently that the very raising of it justifies the imposition of sanctions.") (citations omitted); Perkins v. Commissioner, 746 F.2d 1187, 1188 (6th Cir. 1984) (per curiam) (awarding sanctions for arguing that wages are not income under 16th Amendment); Funk v. Commissioner, 687 F.2d 264, 264 (8th Cir. 1982) (per curiam) (rejecting argument that labor is recovery of capital and not taxable under 16th Amendment); United States $v$. Romero, 640 F.2d 1014, 1016 (9th Cir. 1981) (Romero's proclaimed belief that ... the wages he earned as a carpenter were not 'income' is fatuous as well as obviously incorrect.").
} 
One apparent distinction between ordinary wages and Ms. Murphy's compensatory damages award is that wages involve the voluntary sale of human capital, while Ms. Murphy's injury was involuntary. However, property sold involuntarily, and recoveries for damage to property on account of casualty, have long been treated as taxable in the same general manner as voluntary property sales. ${ }^{444}$ The tax system treats both voluntary and involuntary sales of property for cash the same way. If there is no tax difference between the voluntary and involuntary sale of property for cash, why would there be a constitutional difference between the voluntary and involuntary sale of human capital for cash? After all, according to the court of appeals' theory, human capital is property. The involuntary nature of the income may, as some academics have argued, ${ }^{445}$ constitute policy grounds for Congress to grant an exclusion, as Congress did for many years, but the involuntary nature does not constitute constitutional grounds for treating the recovery as non-taxable tax-cost basis rather than as income. Furthermore, the 16th Amendment on its face makes no distinction between voluntarily and involuntarily received income. The court of appeals' theory that Congress cannot tax recoveries of human capital under the 16th Amendment was not based on the involuntary nature of the recovery.

The proper question in the Murphy case, under the standard laid down by the Supreme Court in Glenshaw Glass, ${ }^{446}$ was whether Ms. Murphy's damages award constituted a realized "accession to wealth." If the award constituted an accession to Ms. Murphy's wealth, then it would constitute "income" under the 16th Amendment. The historic treatment of wage income shows that human capital was not considered wealth when the 16th Amendment was adopted. Without doubt, Ms. Murphy increased her financial wealth when she traded her emotional distress and reputational injuries for cash, just as a laborer receives an increase in financial wealth when she trades her non-taxable leisure time for wages. And just like a laborer who sells human capital in the form of labor for cash, Ms. Murphy realized income that was subject to tax under the 16th Amendment when she sold her human capital in the form of emotional distress damages for cash.

The court of appeals in Murphy tried to distinguish between a monetary recovery on account of human capital in the form of wages, which would be taxable, and a monetary recovery on account of human capital in the form of damages, which would not be taxable, by arguing that non-wage human capital is normally not taxed. ${ }^{447}$ It is certainly true that one's consumption of one's own human capital is not taxed, just as one's consumption of one's own property is not taxed. ${ }^{48}$ However, Ms. Murphy did not

\footnotetext{
${ }^{444}$ IRC $\S 1033$ (a)(2) ("If property (as a result of its destruction in whole or in part, theft, seizure, or requisition or condemnation or threat or imminence thereof) is compulsorily or involuntarily converted ... into money or into property not similar or related in service or use to the converted property, the gain (if any) shall be recognized except to the extent provided in this paragraph [relating to like-kind replacement property purchased within certain time periods thereafter].").

${ }^{445}$ See e.g. Sager \& Cohen, supra note 346, at 477-79 (arguing as a policy matter that compensation for personal injuries should not be taxed because the appreciation in human capital would not be taxed, and the sale was involuntary).

${ }^{446}$ See discussion of Commissioner v. Glenshaw Glass, 328 U.S. 426 (1955), supra beginning at note 402.

${ }^{447}$ See Murphy, 460 F.3d at 88 n.

${ }^{448}$ See Morris v. Commissioner, 9 B.T.A. 1273, 1278 (1928) ("Products of a farm consumed by the operator thereof and his family do not appear to come within any of the categories of income enumerated in the taxing statutes and the administrative regulations of the Commissioner. To include the value of such
} 
consume her own human capital - she sold it for cash. She received cash that she could use to satisfy other (and often more material) desires. Had Ms. Murphy's recovery been in reimbursement of non-deductible medical care expenses to restore her emotional well being, Congress would have allowed her an exclusion. ${ }^{449}$ It was the conversion of her emotional distress to cash that gave rise to realized gain, income and taxation. In sum, the court of appeals utterly failed to demonstrate that Ms. Murphy's recovery of money on account of her emotional or reputational injury was not "income" within the original meaning of the 16th Amendment.

\section{Conclusion.}

The court of appeals in Murphy made many errors in concluding that IRC Section 104(a)(2) was unconstitutional in allowing the government to tax Ms. Murphy's emotional distress and reputational injury award. This paper attempts to analyze the question correctly by first considering the statutory questions: whether Ms. Murphy's award could properly be excluded from income, and if not by considering whether the statute required the award to be included in income.

The court of appeals properly considered whether Ms. Murphy's award was statutorily excluded from income under IRC section 104(a)(2). ${ }^{450}$ However, the court of appeals erred in focusing on the language used in the heading of the award rather than the intent of the Department of Labor hearing board in setting the amount of the award. ${ }^{451}$ The award, in fact, compensated Ms. Murphy for the physical manifestations of her emotional distress. $^{452}$ If Ms. Murphy's physical manifestations of emotional distress constituted a "personal physical injury or physical sickness" under the statute, then Ms. Murphy's award would have been excluded from income under IRC section 104(a)(2), notwithstanding the language used by the hearing board in the heading of the award. The court of appeals in Murphy failed to ask the right question.

Yet, the Court reached the correct result - that Ms. Murphy's award was not statutory excluded from income - because the legislative history of IRC section 104(a)(2) shows that Congress did not intend physical manifestations of emotional distress to

products ... would automatically subject such amounts to normal tax and in effect include in income something which Congress did not intend should be so regarded. If products of a farm consumed thereon are income to the producer, it would seem to follow that the rental value of the farmer's home, the gratuitous services of his wife and children, and the value of the power derived from draft animals owned by the farmer and used without cost should also be so considered. It is obvious that such items are comparable to the rental value of a private residence, which has never been regarded as income or as a factor in the determination of tax liability."). See also Rev. Rul. 59-360, 1959-2 C.B. 75 ; 1959 IRB LEXIS 35, obsoleted by Rev. Rul. 72-619, 1972-2 C.B. 650, 1972 IRB LEXIS 293, Rev. Rul. $72-619$ (1972) ("The value of the use and occupancy of a dwelling by the owner thereof does not constitute gross income to him. However, when transformed into cash, as where an owner rents his property to another, the amounts received constitute gross income.") (citation omitted).

${ }^{449}$ IRC $\S 104(a)(2)$ (flush language) (limitation of exclusion for emotional distress "shall not apply to an amount of damages not in excess of the amount paid for medical care . . . attributable to emotional distress."').

${ }^{450}$ Murphy, 460 F.3d at 83.

${ }^{451}$ See discussion supra Part III.B page 7.

${ }^{452}$ See supra note 30 
constitute a "physical injury or physical sickness" within the meaning of the statute. ${ }^{453}$ This legislative history was relied on by all of the other courts that have considered similar questions, ${ }^{454}$ although curiously none of these cases was cited by the court of appeals in Murphy.

Having properly concluded, for the wrong reason, that Ms. Murphy's award was not excluded from income by IRC section 104(a)(2), the court of appeals should next have considered whether Congress required the award to be included in income by any provision of the IRC. Contrary to the court of appeals' suggestion, the lack of an exclusion does not mandate inclusion. ${ }^{455}$ Congress must affirmatively seek to tax the award. IRC section 61 requires all "income" to be included in "gross income" and thus be subject to taxation. ${ }^{456}$ Because the court of appeals was required to first determine that the statute required taxation before considering the constitutionality of the statute, ${ }^{457}$ the court of appeals must implicitly have determined that Ms. Murphy's award constituted "income" within the meaning of IRC section 61.

The court of appeals' implicit determination was correct, because Congress clearly intended when IRC section 104(a)(2) was amended in 1996 for "income" under section 61 to include those personal injury awards that were no longer excluded from income. Congress made its intent clear in the legislative history, ${ }^{458}$ but its intent was also manifest from the statutory amendment itself. There would be no rational reason for Congress to go to the trouble of specifically eliminating the exclusion if it did not intend to render non-excluded awards taxable. ${ }^{459}$ Under the doctrine of statutory evolution, Congress's intent when it amended IRC section 104(a)(2) is effective for prospectively interpreting the ambiguous meaning of the word "income" in section 61. ${ }^{460}$ Therefore, Congress did seek to tax Ms. Murphy's award in IRC section 61, and it was thus proper for the court of appeals to consider whether Congress's statutory enactment was constitutional.

In considering the constitutionality of the statute, the court of appeals concluded that the 16th Amendment did not authorize Congress to tax Ms. Murphy's award because it was not "income." The court of appeals then held IRC section 104(a)(2) to be unconstititional.

The Court's holding that section 104(a)(2) was unconstitutional was wrong in a number of ways. First, section 104(a)(2) is an exclusion provision. The elimination of an exclusion cannot be unconstitutional because Congress is not required to exclude all things that are not "income." If anything is unconstitutional, it would be IRC section 61, which required Ms. Murphy to include her award in income. ${ }^{461}$

Second, the Court was flat wrong to hold that the 16th Amendment is the sole source of Congress's taxing power. Congress's taxing power emanates from Article I of the Constitution, and includes the power to tax everything except exports. However, the

${ }^{453}$ See discussion supra Part III.C page 10.

${ }^{454}$ See supra note 73.

${ }^{455}$ See discussion supra Part III.D page 14.

${ }^{456}$ See supra note 82.

${ }^{457}$ See supra note 83

${ }^{458}$ See discussion supra beginning at note 84

${ }^{459}$ See discussion supra beginning at note 85 .

${ }^{460}$ See discussion supra beginning at note Error! Bookmark not defined.

${ }^{461}$ See discussion supra beginning at note 80 
Constitution requires Congress to apportion direct taxes. Since the tax on Ms. Murphy's damage award was not apportioned, it would not be valid if it constituted a direct tax and was not "income" within the 16th Amendment. Therefore, the court of appeals should have considered whether or not the tax was direct.

The history of the direct taxing clause shows that only capitation taxes, poll taxes and taxes on real and personal property, and the income therefrom, were ever considered direct, and that human capital in the form of wages was never considered "property" for purposes of the direct taxing clause. ${ }^{462}$ Moreover, the courts have repeatedly treated the taxation of transactions as an indirect "duty or excise," requiring no apportionment. ${ }^{463}$ Ms. Murphy engaged in a transaction when she exchanged her emotional and reputational injuries for money. Thus, even if Congress correctly concluded that the award was not income, Congress had the power to tax the award under the Supreme Court's longstanding interpretations of Congressional power under Article I of the Constitution.

Third, court of appeals erred in concluding that the award was not "income" within the meaning of the 16th Amendment. The court of appeals cited no credible evidence that the enactors of the 16th Amendment intended compensatory damage awards not to be treated as income. ${ }^{464}$ Under the Supreme Court's modern interpretation of income, any realized accession to wealth - which includes any recovery of money from property in excess of basis - is taxable as income. ${ }^{465}$ Individuals generally are not given basis for their investments in their own human capital. ${ }^{466}$ Therefore, any recovery on account of human capital is subject to tax, absent a specific statutory exclusion. This is most evident with wages. The Supreme Court and the Courts of Appeals in every circuit have rejected as frivolous the argument that wages are not income because they represent the recovery of capital.

The court of appeals in Murphy has accepted, for the first time, the vary argument advanced by the most provocative tax protestors ${ }^{467}$ although in a slightly different guise. The argument is that wages, which are recoveries on account of human capital, are not income because there is no gain or accession to wealth, since the market value of the human capital sold equaled the value of the wages received. The courts have repeatedly recognized, however, that because one does not have basis in one's own human capital, the recovery of any money on account of human capital is income, since it results in an accession to one's financial wealth.

Using proper analysis, the Court should have determined that Ms. Murphy's award constituted income under both section 61 and the 16th Amendment, and therefore Congress's tax on the award was valid. Moreover, the court of appeals should have determined that even if the award was not income under the 16th Amendment, the tax on Ms. Murphy's damages award under IRC section 61 was still constitutional because Congress had the power under Article I of the Constitution to tax the award without apportionment as a duty or excise.

\footnotetext{
${ }^{462}$ See discussion in Part IV.A beginning at page 20.

${ }^{463}$ See discussion in Part 0IV.A(6) beginning at page 42

${ }^{464}$ See discussion supra beginning at note 328.

${ }^{465}$ See discussion supra beginning at note 402 .

${ }^{466}$ See discussion supra beginning at note 442 .

${ }^{467}$ See supra note 443.
} 
While valid policy arguments can be made for the exclusion of emotional distress and reputational injury awards, ${ }^{468}$ those policy arguments should be addressed to Congress, not the courts. The Constitution delegates to our elected officials in Congress the power to decide questions of tax policy within the broad limits established by the Constitution. Congress decided to eliminate the exclusion for emotional distress and reputational damages awards because, as explained in the legislative history, Congress sought to minimize unnecessary litigation over the difficult factual question of determining whether an emotional recovery was in lieu of taxable income or not - an inquiry that Congress felt had bogged down the judicial process. ${ }^{469}$ Even if one were to disagree with Congress's policy decisions, Congress's decisions were certainly rational. The remedy for those who disagree with Congress's policy decisions is the ballot box, not the courts. The erroneous decision in Murphy should be promptly overturned.

As of November 3, 2006

${ }^{468}$ See e.g. Sager \& Cohen, supra note 346.

${ }^{469} \mathrm{Id}$. 